\title{
UTILIZAÇÃO DAS FONTES DE CARBONO SACAROSE, GALACTOSE, SORBITOL E GLICEROL POR CÉLULAS IN VITRO DE PLANTAS
}

\author{
MARCIA OMETTO DE MELLO \\ Engenheiro Agrônomo
}

Orientador: Prof. Dr. MURILO DE MELO

Dissertação apresentada à Escola Superior de Agricultura "Luiz de Queiroz", Universidade de São Paulo, para a obtenção do título de Mestre em Ciências, Área de Concentração: Fisiologia e Bioquímica de Plantas.

\author{
PIRACICABA \\ Estado de São Paulo - Brasil \\ Novembro - 1998
}


Dados Internacionais de Catalogação na Publicação (CIP) DIVISÃo DE BIBLIOTECA E DOCUMENTAÇÃO - Campus "Luiz de Queiroz"/USP

\author{
Mello, Marcia Ometto \\ Utilização das fontes de carbono sacarose, galactose, sorbitol e glicerol por células \\ in vitro de plantas / Marcia Omento de Mello. - Piracicaba, 1998. \\ $94 \mathrm{p}$. \\ Dissertação (mestrado) - - Escola Superior de Agricultura Luiz de Queiroz, 1998. \\ Bibliografia.
}

1. Cultura de célula vegetal 2. Feiiäo 3. Galactose 4. Glicólise 5. Gliconeogènese 6. Sacarose 7. Sorbitol 8. Suspensão 9. Zedoaria I. Titulo 
Aos meus pais, Heitor e Norly, que estiveram ao meu lado em todos os momentos, sempre me incentivando,

\section{OFEREÇO.}

Ao meu marido, Luiz Antônio, pelo grande apoio que venho recebendo, DEDICO. 


\section{AGRADECIMENTOS}

Ao Prof. Dr. Murilo de Melo, pela orientação, incentivo, apoio e amizade durante a realização deste trabalho;

Ao CEBTEC, pela oportunidade e apoio técnico recebidos;

Aos Departamentos de Botânica e Química pela oportunidade concebida e pelos ensinamentos recebidos;

À FAPESP, pela concessão da bolsa de estudos;

À Antônio Francisco de Campos Amaral, funcionário do Departamento de Química CEBTEC, pelo apoio técnico na realização dos experimentos e pela amizade;

Aos Profs. Décio Barbin e Carlos Tadeu dos Santos Dias, pelo apoio na realização das análises estatísticas;

A todos os colegas, professores e funcionários dos Departamentos de Botânica e Química da ESALQ/USP que, de alguma maneira, colaboraram para a realização deste trabalho;

Às funcionárias do Setor de Biblioteca da ESALQ/USP, pela amizade e auxílio prestados. 


\section{SUMÁRIO}

Página

RESUMO $\mathrm{X}$

SUMMARY xii

1- INTRODUÇÃO

2- REVISÃO DE LITERATURA .

2.1- O metabolismo de carbono in vivo 3

2.1.1- Glicólise e gliconeogênese 3

2.1.2- A regulação da glicólise e da gliconeogênese 7

2.2-O metabolismo de carbono in vitro 10

2.3- Fontes de carbono importantes 12

2.3.1- Sacarose 13

2.3.2- Sorbitol 14

2.3.3- Galactose 18

2.3.4- Glicerol 20

3- MATERIAL E MÉTODOS 23

3.1- Meio básico de cultura 23

3.2- Bauhinia forficata Link 23

3.2.1- Germinação de embriões 23

3.2.2- Estabelecimento da cultura de calos 24

3.2.3- Estabelecimento da cultura de células em suspensão . 25

3.3-Curcuma zedoaria Roscoe 25

3.3.1- Estabelecimento da cultura de calos 25

3.3.2- Estabelecimento da cultura de células em suspensão 26

3.4- Phaseolus vulgaris 26

3.4.1- Estabelecimento da cultura de calos 26

3.4.2-Estabelecimento da cultura de células em suspensão 
3.5- Teste do efeito de diferentes fontes de carbono ................................... 27

3.6- Estudo do ganho de biomassa ......................................................... 28

3.7- Preparo do extrato para análise da atividade enzimática .......................... 28

3.8- Análise da atividade enzimática .......................................................... 29

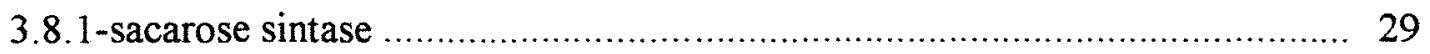

3.8.2-uridina difosfato glicose pirofosforilase ............................................ 30

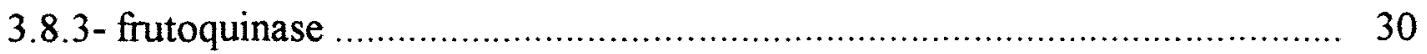

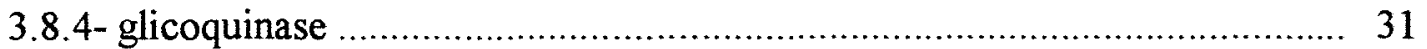

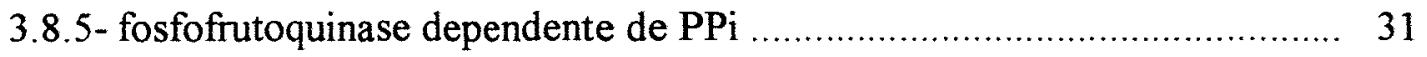

3.8.6- fosfofrutoquinase dependente de ATP ou UTP ……........................... 32

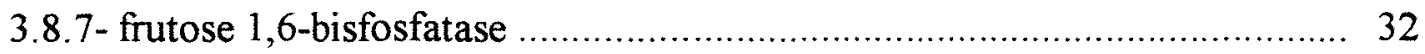

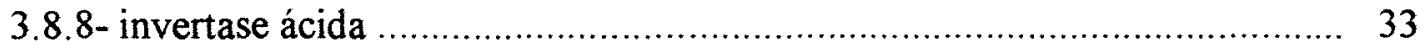

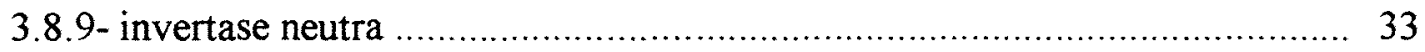

3.8.10- sorbitol desidrogenase NAD-dependente …..................................... 34

3.8.11-glicose 6-fosfato desidrogenase ....................................................... 34

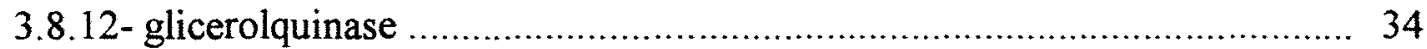

3.8.13-glicerol 3-fosfato desidrogenase ……........................................... 35

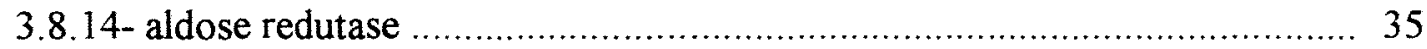

3.9- Cálculo e expressão da atividade das enzimas......................................... 36

3.10- Análise da concentração protéica......................................................... 36

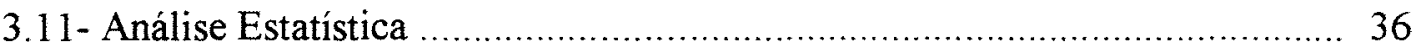

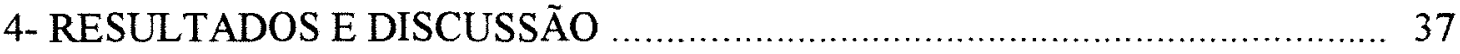

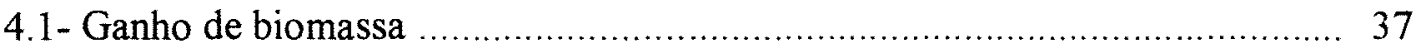

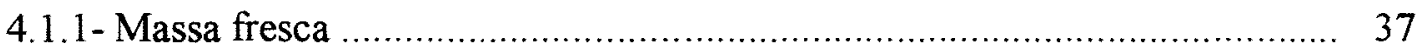

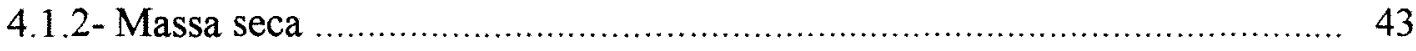

4.2- Acúmulo de proteína ....................................................................... 49

4.3- Atividade das enzimas do metabolismo de carboidratos .......................... 53

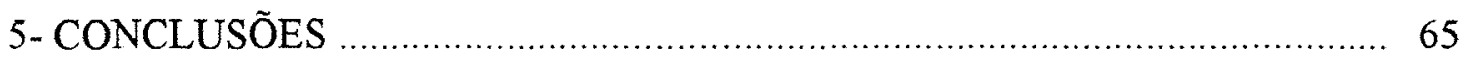




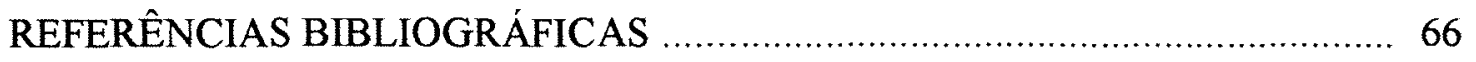

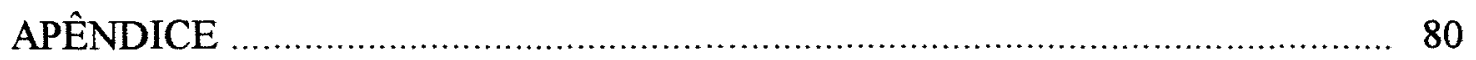




\section{LISTA DE ABREVIATURAS}

$\mathrm{ADP}=$ adenosina di-fosfato

AMP $=$ adenosina mono-fosfato

ATP $=$ adenosina tri-fosfato

$\mathrm{BAP}=$ benzil amino-purina

$\mathrm{BSA}=$ soro albumina bovina

$\mathrm{CO}_{2}=$ dióxido de carbono

2,4-D = ácido 2,4-dicloro fenoxiacético

DHAP $=$ dihidroxi acetona fosfato

DTT $=$ ditriothreitol

EDTA. $\mathrm{Na}_{2}=$ etilenodiaminatetra acetato dissódico

$\mathrm{gal}=$ galactose

HEPES = ácido N (2-hidroxietil) piperazine N (2-etanosulfonico)

$\mathrm{K}_{2} \mathrm{HPO}_{4}=$ fosfato dibásico de potássio

$\mathrm{KOH}=$ hidróxido de potássio

$\mathrm{Mg}$ = magnésio

NAA = ácido naftaleno acético

$\mathrm{NAD}(\mathrm{P})=$ nicotinamida adenina binucleotídeo (fosfato)

$\mathrm{NAD}(\mathrm{P}) \mathrm{H}=$ nicotinamida adenina binucleotídeo (fosfato) reduzida

$\mathrm{OH}^{-}=$hidroxila

$\mathrm{P}=$ fósforo

$\mathrm{PEP}=$ fósforo enol piruvato

3-PGA = ácido 3-fosfoglicérico

$\mathrm{Pi}=$ fosfato inorgânico

$\mathrm{PPi}=$ pirofosfato inorgânico

$\mathrm{PVP}=$ polivinil pirrolidone

$\mathrm{rpm}=$ rotações por minuto

TCA $=$ ciclo dos ácidos tricarboxílicos

UDP $=$ uridina difosfato 
UDPG = uridina difosfato glicose

UTP = uridina trifosfato 


\title{
A UTILIZAÇÃO dE FONTES ALTERNATIVAS DE CARBONO POR CÉlULAS IN VTTRo dE PLANTAS
}

\author{
Autora: MARCIA OMETTO DE MELLO \\ Orientador: Prof. MURILO DE MELO
}

\section{RESUMO}

Os carboidratos galactose, sorbitol e glicerol foram usados para se avaliar a capacidade de células in vitro de plantas em utilizar fontes alternativas de carbono em culturas de células em suspensão de três diferentes espécies (Bauhinia forficata Link, Curcuma zedoaria Roscoe e Phaseolus vulgaris). Culturas crescendo em sacarose como fonte de carbono foram usadas como controle.

A sacarose foi a fonte de carbono que condicionou os melhores resultados de crescimento expressos em ganho de massa fresca e massa seca, bem como de acúmulo protéico para as três espécies testadas. $O$ glicerol e o sorbitol não proporcionaram ganho significativo de massa fresca e nem de massa seca nas culturas de nenhuma das três espécies testadas, exceto um pequeno ganho de massa seca observado para $B$. forficata quando o glicerol foi empregado como fonte de carbono. A galactose proporcionou aumento de massa fresca e massa seca apenas em culturas de C. zedoaria e B. forficata, sendo que este aumento foi inferior ao proporcionado pela sacarose nas culturas das mesmas espécies.

A análise da atividade das enzimas do metabolismo da sacarose indicou que culturas de células em suspensão de $C$. zedoaria e de $P$. vulgaris apresentam as duas vias de degradação da sacarose; a via clássica caracterizada pela atividade das enzimas invertases e hexoquinase e a via alternativa caracterizada pela atividade das enzimas sacarose sintase e UDP glicose pirofosforilase. A ausência de atividade da enzima 
sacarose sintase nas culturas de Bauhinia sugere que células em suspensão desta espécie degradam a sacarose apenas pela via clássica. 


\title{
UTILIZATION OF ALTERNATIVE SOURCES OF CARBON BY IN VITRO PLANT CELLS
}

\author{
Author: MARCIA OMETTO DE MELLO \\ Adviser: Prof. MURILO DE MELO
}

\section{SUMMARY}

Galactose, sorbitol and glycerol were the carbohydrates used to evaluated the capability of plant cells in vitro to utilize alternative carbon sources in cell suspension cultures of three different plant species (Bauhinia forficata Link, Curcuma zedoaria Roscoe and Phaseolus vulgaris). Cultures growing in sucrose as carbon source were used as control.

Sucrose was the carbon source which led to the best results of fresh and dry weight increase, as well as of protein content for all the three species studied. Glycerol and sorbitol did not promote significant increase of fresh and dry weights for any of the three species tested, except the increase in dry weight observed in B. forficata when glycerol was used as carbon source. Galactose led to an increase of these parameters in cultures of $C$. zedoaria and B. forficata always smaller than the one obtained with the use of sucrose as carbon source.

The activities of the sucrose metabolism enzymes showed that all suspension cultures of $C$. zedoaria and $P$. vulgaris developed the two pathways for sucrose degradation; the classic pathway and the alternative pathway characterized by sucrose synthase and UDP glucose pirophosphorilase activities. The absence of sucrose synthase activity in cell cultures of $B$. forficata suggests that cell suspension cultures of this species cleavage sucrose only by the classic pathway. 


\section{1- INTRODUÇÃO}

Com raras exceções, células de plantas cultivadas in vitro não são autotróficas e uma fonte de carbono utilizável necessita ser adicionada ao meio de cultura para propiciar crescimento e multiplicação celular satisfatórios. Messner \& Berndt (1990), avaliaram a capacidade fotossintética de células in vitro de Picea abies e concluiram que estas células embora tivessem cloroplastos e fossem fotossinteticamente ativas, não eram autotróficas, necessitando de uma fonte de carbono para sua manutenção. Leifert et al. (1995) sugerem que este fato ocorre devido a insuficiência de luz das salas de crescimento.

A sacarose é a fonte de carbono mais comumente adicionada aos meios de cultura e utilizada por células in vitro. Com variáveis intensidade, outras fontes de carbono como a glicose, frutose, galactose, manose, glicerol, maltose e sorbitol, sozinhas ou em combinação, vêm ocasionalmente sendo utilizadas.

Alguns autores estudaram o emprego de fontes alternativas de carbono no meio de cultura, incluindo glicerol em Citrus (Singh et al., 1992) e em Cichorium (Helleboid et al., 1995); galactose em Triticum aestivum (Navarro, 1994), em Dioscorea rotundata (Okezie et al., 1994) e em Citrus (Cabasson et al., 1995); sorbitol em Oryza sativa (Yoshida et al., 1994), em Lilium (Okazaki et al., 1995), em Vaccinium (Sidorovich et al., 1995), em Quercus suber (Romano et al., 1995) e em Prunus armeniaca (Murai et al., 1996).

A razão para se testar a capacidade de diferentes monossacarídeos, dissacarídeos e outros derivados de açúcares como promotores do crescimento de culturas celulares de plantas é que uma fonte de carbono específica pode resultar em maior diversidade de 
metabólitos devido a ativação de rotas alternativas do metabolismo estimuladas pela mudança do fluxo de carbono (Jones \& Veliky, 1980).

Segundo Leifert et al. (1995), muitos dos fatores que afetam o crescimento de tecidos e células in vitro, como fitorreguladores, luz, temperatura, $\mathrm{pH}$ do meio, umidade, trocas gasosas e presença de microorganismos, foram estudados intensamente nos últimos 30 anos. Por outro lado, as necessidades nutricionais como nutrientes minerais, carboidratos e outros compostos orgânicos, além de fatores que afetam a utilização dos nutrientes e crescimento de plantas in vitro, raramente tem sido estudados e continuam sendo pouco entendidos. Ainda segundo os autores, os trabalhos realizados para suplementação com carboidratos foram feitos em somente algumas espécies, buscando sempre a melhor combinação fonte de carbono e concentração que maximizasse o crescimento e desenvolvimento daquelas espécies, ou seja, buscando o modelo espécie versus fonte de carbono específica ao invés de estudar os mecanismos de aproveitamento destas fontes de carbono pelas células, assim como as enzimas que supostamente estariam envolvidas neste aproveitamento.

Os aspectos fundamentais da utilização do carbono e metabolismo em culturas de células em suspensão e calos de espécies vegetais e o modo com que as fontes exógenas de carbono entram no metabolismo dos tecidos, ainda necessitam ser definidos e entendidos (Kozai, 1991; Vu et al., 1993).

Em vista do cenário atual da utilização de fontes alternativas de carbono in vitro, o objetivo do presente trabalho é o de testar a capacidade de aproveitamento da sacarose, galactose, sorbitol e glicerol por culturas de células em suspensão de três espécies de plantas, através da evolução dos teores de massa fresca, massa seca e proteína, além de estudar algumas das enzimas do metabolismo de carbono nestas células. 


\section{2- REVISÃO DE LITERATURA}

\section{1- O metabolismo de carbono in vivo}

\subsection{1- Glicólise e Gliconeogênese}

A glicólise é uma via catabólica aeróbica que apresenta basicamente dois papéis fundamentais (Plaxton, 1996). Ela oxida hexoses para gerar ATP, agentes redutores e esqueleto carbônico para as reações anabólicas. Além disto, a glicólise é uma via anfibólica porque pode funcionar de maneira inversa gerando hexose a partir de vários metabólitos mais oxidados de pesos moleculares baixos, num processo conhecido como gliconeogênese. Assim a glicólise é de crucial importância para as plantas porque além de direcionar compostos para a respiração, grande parte dos carbonos que entram na glicólise, no ciclo das pentoses fosfato e no ciclo dos ácidos tricarboxílicos (TCA) não é oxidada a $\mathrm{CO}_{2}$ mas sim utilizada na biossíntese de vários compostos como metabólitos secundários, isoprenóides, amino-ácidos, ácidos nucléicos e ácidos graxos (Plaxton, 1996).

Segundo Sung et al. (1988), a glicólise e a gliconeogênese em animais e microorganismos tem início e fim com uma molécula de glicose. Porém, em células de plantas é mais apropriado dizer que a glicólise começa e a gliconeogênese termina com a degradação e a síntese de sacarose, respectivamente. Ainda segundo os autores, a sacarose pode entrar no citoplasma de uma célula de planta via plasmodesmata, vinda de uma célula adjacente, ou via parede celular, pelos espaços livres da membrana plasmática. 
São três as enzimas responsáveis pela degradação da sacarose (Sung et al., 1988). As células de plantas possuem a invertase ácida que se localiza na parede/membrana celular ou no vacúolo, a invertase alcalina e a sacarose sintase localizadas no citoplasma. As invertases ácida e alcalina catalisam a quebra irreversivel da sacarose em glicose e frutose, na qual a energia da ligação glicosídica é perdida e os produtos convertidos pela ação da hexoquinase em glicose 6-P e frutose 6-P. Por outro lado, a sacarose sintase quebra a sacarose formando UDP-glicose e frutose. A frutose formada é fosforilada pela frutoquinase a frutose 6-P e a UDP-glicose, pela ação da UDP-glicose pirofosforilase, é transformada em glicose 1-P. Nesta reação, a energia da ligação glicosídica é conservada na UDP-glicose. A combinação das enzimas sacarose sintase e UDP-glicose pirofosforilase podem fornecer glicose 1-P diretamente na via glicolítica através da utilização do UDP e do PPi e pela ação da fosfoglicomutase (PGM) que converte glicose 1-P em glicose 6-P (Black et al., 1987). Cada uma destas três alternativas de degradação da sacarose conduz a formação de hexose 6-P. Sabe-se que a glicose 6-P pode ser oxidada pela via das pentoses fosfato ou pode ser convertida a frutose $6-\mathrm{P}$ e daí até trioses fosfato pelas reações da glicólise.

De forma geral, a degradação da sacarose pode ocorrer pela via conhecida como clássica, que envolve a atividade das enzimas invertases e hexoquinase ou pela via alternativa que envolve as enzimas sacarose sintase e UDP-glicose pirofosforilase (Huber \& Akazawa, 1986).

Segundo Black et al. (1987), a quebra da sacarose via sacarose sintase requer a metade da energia líquida requerida pela via das invertases. O pirofosfato, necessário para a ação desta enzima, ocorre como reserva em tecidos de plantas para reações de biossintese como aquelas que funcionam na quebra de açúcares exógenos onde as enzimas PPi-fosfofrutoquinase e UDP-glicose pirofosforilase atuam. Além disto, o pirofosfato une as vias glicolítica e gliconeogênica e, de maneira recíproca, é formado como fonte de energia durante a gliconeogênese, na sintese de sacarose.

A interconversão entre frutose 6-fosfato e frutose 1,6-bisfosfato é um dos passos que apresenta alto grau de controle tanto na glicólise como na gliconeogênese (Boll, 1991). O fluxo de carbono em direção a formação de frutose 6-fosfato é controlado pela 
atividade relativa das enzimas ATP-fosfofrutoquinase e da frutose 1,6-bisfosfatase. Em plantas, uma outra enzima está envolvida nesta reação, a qual reversivelmente interconverte frutose 6-fosfato/frutose 1,6-bisfosfato e pirofosfato inorgânico/fosfato (Carnal \& Black, 1983). Esta enzima localizada no citoplasma é conhecida como PPifosfofrutoquinase e pode ter atividade igual ou maior do que a atividade da ATPfosfofrutoquinase, dependendo do tecido da planta (Carnal \& Black, 1983; Copeland et al., 1989), afetando assim significativamente o metabolismo de açúcares. Carnal \& Black (1983), destacam que o fato da enzima PPi-fosfofrutoquinase ocorrer somente no citoplasma das células de plantas enquanto a ATP-fosfofrutoquinase ocorre tanto no citoplasma como no cloroplasto, claramente embasa a possibilidade de que duas vias glicolíticas ocorrem nas células clorofiladas. Segundo Plaxton (1996), a compartimentalização isola as enzimas e os metabólitos associados à uma via metabólica, prevenindo assim a ocorrência de processos metabólicos incompatíveis bem como competitivos. A função das isoenzimas da glicólise nos cloroplastos no escuro e nos plastídeos não-fotossintetizantes é de participar da quebra do amido, assim como de gerar esqueleto carbônico, agentes redutores e ATP para as vias anabólicas como a gliconeogênese, a síntese de ácidos graxos e outras (Plaxton, 1996).

$\mathrm{O}$ gliceraldeído 3-P pode ser oxidado diretamente a 3-PGA pela enzima gliceraldeído 3-P desidrogenase dependente de NAD sem síntese de ATP ou, através da ação de duas enzimas, a gliceraldeído 3-P desidrogenase e a 3-PGA quinase, com a formação de NADH e ATP, respectivamente (Sung et al., 1988).

Finalmente o último passo na glicólise que leva a formação de piruvato pode ocorrer pela ação de três enzimas: a PEP fosfatase, a piruvato Pi diquinase e a piruvato quinase sendo esta última considerada uma das principais enzimas para a glicólise (Sung et al., 1988).

Segundo Plaxton (1996), células de plantas podem empregar uma rota metabólica alternativa para substituir a reação catalisada pela piruvato quinase do citosol. A PEP carboxilase, uma enzima presente no citosol de células de plantas, tem o importante papel de repor os intermediários do TCA, consumidos durante a biossíntese, nas plantas $\mathrm{C} 3$, tecidos não fotossintetizantes das plantas $\mathrm{C} 4$ e plantas com metabolismo ácido das 
crassuláceas (CAM). Porém, conjuntamente com a enzima malato desidrogenase do citosol e com a NAD-enzima málica da mitocondria, a PEP carboxilase pode atuar como enzima glicolítica, substituindo a reação catalisada pela enzima piruvato quinase que transforma PEP em piruvato.

Segundo Sung et al. (1993), dois grupos de enzimas aparecem como sendo responsáveis pela via glicolítica em plantas e são denominadas adaptativas e de manutenção. As enzimas adaptativas apresentam grandes mudanças em curto espaço de tempo em sua atividade como resposta às mudanças ambientais e de crescimento e desenvolvimento das plantas. Por outro lado, as enzimas de manutenção possuem atividades altas ou baixas, porém, estas atividades independem do ambiente ou do estatus da planta. As enzimas sacarose sintase, invertase ácida e PPi-fosfofrutoquinase, foram identificadas como adaptativas em vários tecidos de plantas estudados, enquanto que invertase neutra e ATP-fosfofrutoquinase foram caracterizadas como enzimas de manutenção por não apresentarem mudanças maiores do que duas vezes nas suas atividades.

Cada triose fosfato que sai do cloroplasto é trocada por um fosfato inorgânico (Pi). No citoplasma, duas moléculas de DHAP ou de gliceraldeído 3-P são transformadas em frutose 1,6-bisfosfato pela ação da enzima aldolase. Como discutido anteriormente, frutose 1,6-bisfosfato pode sofrer a ação de duas enzimas, a frutose 1,6 bisfosfatase ou a PPi-fosfofrutoquinase, para formar frutose 6-P + ATP ou PPi, respectivamente. A frutose 6-P formada + UDPG reagem com a enzima sacarose fosfato sintase tendo como produto da reação a formação de sacarose 6-P. Esta última é utilizada como substrato pela enzima sacarose fosfato fosfatase, gerando sacarose e $\mathrm{Pi}$. Portanto, a síntese de sacarose ocorre via sacarose fosfato sintase e sacarose fosfato fosfatase, já que em concentrações fisiológicas dos substratos, a sacarose sintase não forma sacarose (Sung et al., 1988).

A maioria das células de plantas superiores recebem via floema o carbono orgânico na forma de sacarose sintetizada no citoplasma das células clorofiladas, sendo que uma grande parte dos fotossintetizados pode permanecer nos plastídeos na forma de amido. Resultados obtidos por Journet \& Douce (1985), com plastídeos de Brassica 
oleracea, demonstram que estas organelas possuem todas as enzimas necessárias para converter o amido a triose-P e vice-versa. Além disto, as atividades e seus mecanismos de controle das enzimas dos plastídeos de couve-flor permitem diferentes combinações de rotas metabólicas envolvidas no metabolismo das hexoses fosfato: conversão a triose$\mathrm{P}$ envolvendo enzimas como as da glicólise ou oxidação à $\mathrm{CO}_{2}$ e triose-P pela via das pentoses fosfato. A intensidade de cada uma destas vias que está ligada à necessidade do citosol e dos plastídeos é que determina a forma com que a partição entre as rotas no fluxo de carbono ocorre. É interessante citar que a ocorrência das enzimas hexoquinase e ADP-glicose pirofosforilase no plastídeo é que possibilita a completa seqüência de transformação de glicose em amido dentro desta organela. Por outro lado, o complexo da piruvato desidrogenase dependente de CoA, que também está presente nesta organela, mostra a possibilidade de se converter piruvato a acetil-CoA que seria utilizada para a síntese de ácidos graxos.

Tanto a glicólise como a gliconeogênese em plantas são diferentes daquelas que ocorrem nos animais e, a razão destas diferenças é a coexistência das duas rotas durante todo o dia, pela necessidade de sintetizar sacarose que é a forma translocável de carbono, além de em situações adaptativas, garantir que as plantas respondam de maneira dinâmica às mudanças ambientais que ocorrem durante a sua vida (Sung et al., 1988).

\subsection{2- A regulação da glicólise e da gliconeogênese}

A magnitude do fluxo dos metabólitos através de uma via metabólica depende das propriedades que expressam a atividade de cada enzima envolvida. Segundo Plaxton (1996), os controles do metabolismo ao nível enzimático chamados de ajuste grosso e ajuste fino podem modificar a velocidade de reação de uma enzima específica in vivo. No ajuste grosso ocorre a variação da população total de moléculas da enzima através da regulação nas taxas de biossíntese ou proteólise, o que geralmente ocorre durante a diferenciação de tecidos ou durante a adaptação à mudanças no ambiente por períodos mais longos. Por outro lado, o ajuste fino modula a atividade das enzimas 
existentes através do reconhecimento das necessidades momentâneas do metabolismo celular e, assim, controla a taxa do fluxo metabólico para as várias vias. $\mathrm{Na}$ maioria das vezes o ajuste fino age sobre as enzimas que catalisam as reações enzimáticas que envolvem transferência de fosfato como as conversões de hexose a hexose-P, frutose 6-P a frutose 1,6-bisfosfato e PEP a piruvato, bem como as enzimas alostéricas.

Pelo menos seis são os mecanismos de controle ou ajuste fino conhecidos até o presente (Plaxton, 1996). Entre eles podemos destacar a variação na concentração de substrato e cofator, variação de $\mathrm{pH}$, alosteria, associação - dissociação de subunidades, modificações covalentes reversíveis e formação de complexo enzimáticos.

Segundo Huber (1986), a concentração in vivo de frutose 2,6-bisfosfato, conhecida como um importante regulador de enzimas fosforilativas chave do metabolismo de carboidratos (Nielsen, 1995), é função da atividade relativa da enzimas frutose 6-P quinase e frutose 2,6 bisfosfatase, ambas sensiveis a regulação metabólica. A frutose 6-P quinase, responsável pela síntese de frutose 2,6-bisfosfato, é ativada por Pi e inibida por DHAP e PGA (Figura 1). Em baixas concentrações, a frutose 2,6-bisfosfato, aumenta significativamente a atividade da PPi-fosfofrutoquinase, reduz a atividade da frutose 1,6-bisfosfatase e da glicose 6-P desidrogenase e não afeta a atividade da ATPfosfofrutoquinase (Huber, 1986; Black et al., 1987; Sung et al., 1988; Nielsen, 1995).

$O$ aumento da concentração de frutose 2,6-bisfosfato inibirá a atividade da frutose 1,6-bisfosfatase do citosol, diminuindo assim a taxa de formação de sacarose sob condições limitantes (Huber, 1986). Nesta situação, o aumento da concentração de frutose 2,6-bisfosfato pode ser atribuído a diminuição da concentração de DHAP, que aumentaria a atividade da frutose 6-P quinase. A variação na concentração de DHAP é bastante dependente da taxa fotossintética. Nestas condições também, o aumento de Pi inibe a atividade da frutose 2,6-bisfosfatase.

Por outro lado, quando a produção de sacarose é muito alta e excede os níveis de exportação, ela se acumula em níveis mais elevados que o normal e os fotossintetizados são desviados para a produção de amido. Esta mudança na partição de carbono entre a síntese de sacarose e amido está associada com o aumento da concentração de frutose 2,6-bisfosfato, que inibirá a frutose 1,6-bisfosfatase do citosol, diminuindo o fluxo de 
carbono para sacarose. Isto restringirá a exportação de triose-P para fora do cloroplasto e estimulará a síntese de amido. Sob condições de excessivo acúmulo de sacarose, ocorre um aumento da concentração de frutose 6-P maior do que o aumento observado na concentração de DHAP. Enquanto a frutose 6-P é considerada um ativador da frutose 6$\mathrm{P}$ quinase, a DHAP é considerada um inibidor desta enzima (Figura 1). Além disto, a frutose 6-P inibe diretamente a atividade da frutose 2,6-bisfosfatase (Figura 1). Consequentemente, como resultado, temos o aumento na concentração de frutose 2,6bisfosfato (Huber, 1986).

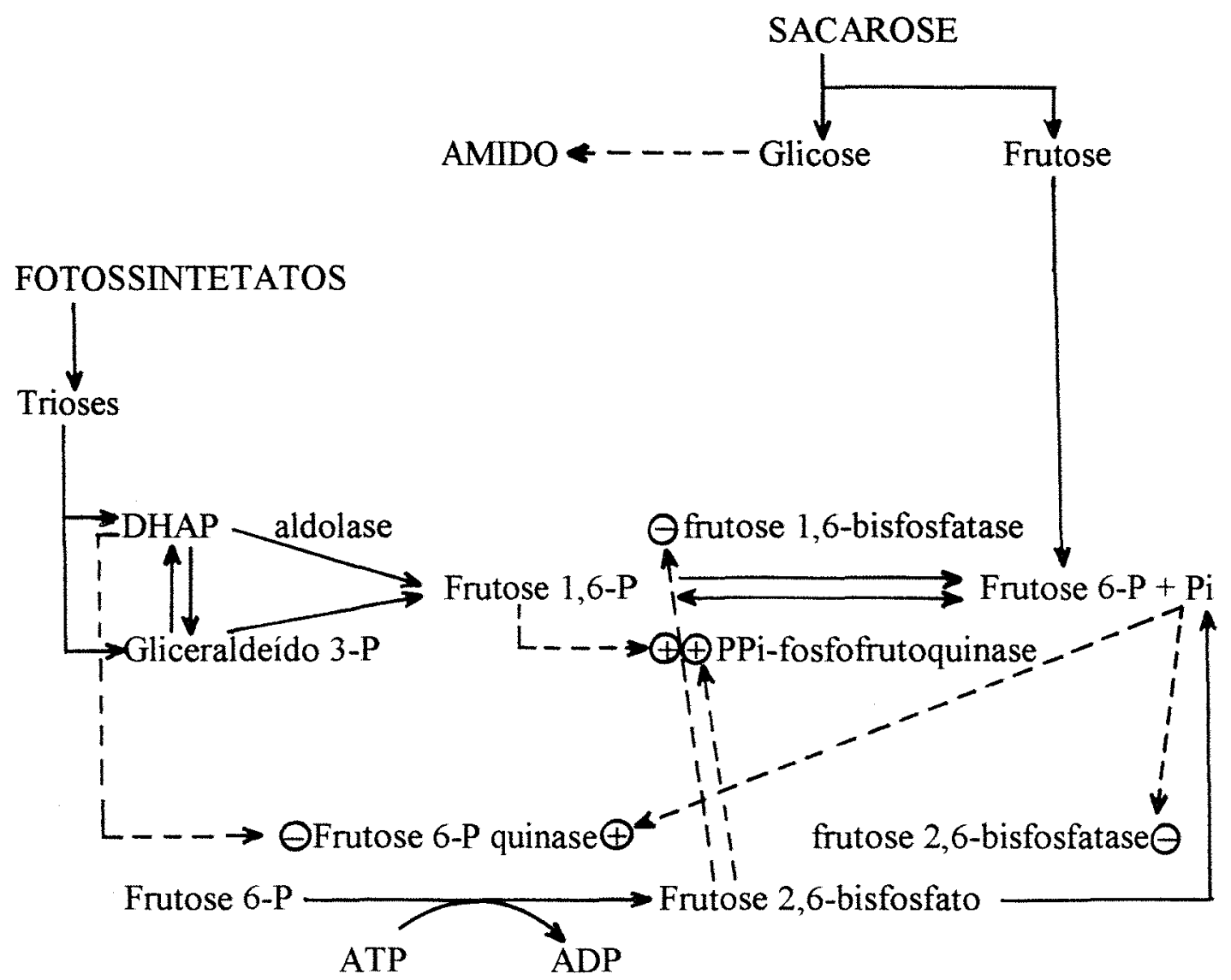

Figura 1: Regulação da glicólise e da gliconeogênese por seus metabólitos intermediários $(\Theta$ inibição, $\oplus$ ativação). 
A frutose 1,6-bisfosfato é um ativador alostérico da enzima PPifosfofrutoquinase, que substitui a frutose 2,6-bisfosfato (Figura 1) (Nielsen, 1995). Segundo o autor, esta afirmação explica porque a atividade desta enzima, quando testada na direção inversa, não é dependente de frutose 2,6-bisfosfato. Nestas condições, a concentração de frutose 1,6-bisfosfato é aparentemente suficiente para substituir a frutose 2,6-bisfosfato na ativação da PPi-fosfofrutoquinase. Portanto a concentração de frutose 1,6-bisfosfato pode ser um importante fator para se determinar a atividade da PPi-fosfofrutoquinase in vivo. Esta ativação específica por frutose 1,6-bisfosfato sugere um papel importante desta enzima na gliconeogênese. Acredita-se que a PPifosfofrutoquinase contribuiria desta maneira para a síntese de sacarose em folhas jovens onde a atividade da frutose 1,6-bisfosfatase é tipicamente baixa.

\section{2- O metabolismo de carbono in vitro}

Embora muitos aspectos do metabolismo de carbono in vivo estejam bem esclarecidos, parece que o nosso conhecimento do metabolismo de carbono in vitro e sua relação com o crescimento e morfogênese ainda é bastante limitado (Swedlund \& Locy, 1993).

Em culturas de calos e células em suspensão de Picea abies, crescendo mixotróficamente em presença de diferentes carboidratos, as atividades das enzimas do metabolismo de carbono foram de 1 a 7 vezes superiores à atividade encontrada em plântulas da mesma espécie com crescimento autotrófico. A incubação das plântulas em solução mineral contendo carboidratos resultou num rápido aumento da atividade daquelas enzimas alcançando os níveis encontrados em culturas de calos e células em suspensão. Além disto, durante o cultivo prolongado das culturas de células em suspensão, quando o carboidrato se tornou limitante, a atividade das enzimas diminuiu gradativamente. Estas duas informações sugerem que a presença ou ausência de carboidrato regula as enzimas da glicólise em Picea abies (Boll, 1991).

Cultura de células em suspensão de Beta vulgaris crescendo em meio suplementado com sacarose apresentava alta atividade da enzima invertase ácida ligada 
à parede celular (Zamski \& Wyse, 1985). Esta evidência pode ser confirmada pelo fato de que a sacarose do meio de cultura era completamente hidrolisada após três dias.

Em culturas de células de Acer pseudoplatanus cultivadas em sacarose, as atividades da sacarose sintase, invertase neutra, glicoquinase e frutoquinase foram semelhantes entre si. O extrato celular continha alta atividade das enzimas uridina difosfato glicose pirofosforilase, fosfoglicomutase e fosfoglicoisomerase (maior ou igual a $200 \mathrm{nmol} / \mathrm{mg}$ proteína $\times \mathrm{min}$ ). As células da cultura apresentavam atividades das duas enzimas da conversão de frutose 6-fosfato a frutose 1,6-bisfosfato, a ATPfosfofrutoquinase e a PPi-fosfofrutoquinase. Não foi detectada a atividade das enzimas sacarose fosforilase e ADP e UDP-fosforilase (Huber \& Akazawa, 1986). Os autores sugeriram a ocorrência das duas vias de degradação da sacarose no metabolismo das células de Acer pseudoplatanus. Além da via que é iniciada pelas invertases, uma outra via que envolve a sacarose sintase e uridina difosfato glicose pirofosforilase foi proposta estar ocorrendo. Esta última forneceria glicose 1-P na glicólise para a posterior degradação ao nível de triose fosfato e estaria envolvida na reciclagem de uridilatos (UTP e UDP) e de pirofosfato. Ainda segundo os autores, a enzima PPifosfofrutoquinase estaria funcionando na direção da glicólise, contribuindo com a via das invertases.

Boll (1991), também propôs a ocorrência das duas vias de degradação da sacarose em culturas de calos e de células em suspensão de Picea abies. As culturas mantidas em sacarose apresentaram atividade em nivel limitante (inferiores a 100 $\mathrm{nmol} / \mathrm{min} \times \mathrm{mg}$ proteína) das enzimas hexoquinase, ATP-fosfofrutoquinase, frutose 1,6bisfosfatase e piruvato quinase enquanto altas atividades (superiores a $500 \mathrm{nmol} / \mathrm{min} \mathrm{x}$ mg proteina) foram detectadas para as enzimas fosfoglicomutase, fosfoglicoisomerase, triosefosfato isomerase e fosfoglicerato quinase. As enzimas sacarose sintase, uridina difosfato glicose pirofosforilase e PPi-fosfofrutoquinase, também estavam presentes no extrato destas culturas.

Culturas de calos de Citrus sinensis crescendo em meio suplementado com sacarose ou glicerol, foram utilizadas para o estudo de enzimas do metabolismo da sacarose por Vu et al. (1993). A atividade da sacarose fosfato sintase em calos crescendo 
em meio com sacarose não se alterou durante os primeiros 14 dias. Por sua vez, houve um aumento de 70\% na atividade aos 21 dias e um decréscimo de 50\% da taxa inicial aos 35 dias. Ao contrário, a atividade da sacarose fosfato sintase em calos crescendo em meio com glicerol, comparado com o dia 0 , aumentou cerca de $60 \%$ nos dias 7 e 14 , $280 \%$ no dia 21 e $390 \%$ no dia 35 , respectivamente, quando comparado com calos crescendo em sacarose. A concentração protéica de calos crescendo em sacarose não se alterou muito em 35 dias, ao contrário do que ocorreu com calos cultivados em glicerol. Segundo os autores, houve considerável acúmulo de amido tanto nas células cultivadas em sacarose como em glicerol.

Segundo Vu et al. (1995), culturas de células em suspensão de Citrus sinensis utilizam eficientemente o glicerol como fonte de carbono para a síntese dos açúcares necessários para o seu crescimento e diferenciação celular, sendo que isto foi confirmado pela atividade das enzimas do metabolismo da sacarose. O aumento significativo da atividade das enzimas envolvidas no metabolismo da sacarose estimulado pelo cultivo das células em glicerol, pode ser considerado o fator principal da indução da embriogênese somática nestas condições (Vu et al., 1995).

Frick (1994), encontrou atividade das enzimas invertase ácida e alcalina e sacarose sintase em calos de Lemna minor e Callitriche stagnalis crescendo in vitro em sacarose ou galactose ou sorbitol como fonte de carbono. Este autor ainda concluiu que o crescimento nas fontes alternativas de carbono só era possível com a diminuição das reservas de açúcares redutores e amido das células e com a diminuição da atividade especifica das invertases ácida e alcalina e da sacarose sintase.

\section{3- Fontes de carbono importantes}

As fontes de carbono, quando são limitantes para o crescimento, promovem a biossíntese de compostos secundários em microorganismos. Este efeito é mediado pelo AMP cíclico. Tanto em procariotos como em eucariotos, o AMP cíclico induz a diferenciação celular quando os carboidratos são limitantes para o crescimento. As plantas por serem autotróficas, normalmente não teriam a necessidade para tal controle, 
mas quando estas são postas em cultura sob condições heterotróficas, elas se comportam como microorganismos, dependendo portanto de uma fonte exógena de carbono. Sob estas condições, tal mecanismo regulatório pode ocorrer (Kinnersley \& Henderson, 1988).

Pouca atenção tem sido dada para se associar efeitos na morfogênese das culturas e produção de compostos secundários com as fontes alternativas de carbono em que as células estão crescendo (Kinnersley \& Henderson, 1988). Poucos são os trabalhos que têm destacado o efeito que as fontes de carbono podem ter sobre o grau e o tipo de diferenciação, e portanto, na morfogênese das culturas (Swedlund \& Locy, 1993). Várias fontes de carbono, que não a sacarose, têm sido usadas para a indução da organogênese (Belyanskaya et al., 1994; Karhu 1995; Murai et al., 1996), embriogênese somática (Lorenzo et al., 1994; Navarro, 1994; Helleboid et al., 1995; Okazaki et al., 1995) ou micropropagação (Hammatt, 1993; Marino et al., 1993; Romano et al., 1995; Sidorovich et al., 1995) de plantas in vitro.

Vários carboidratos, além da sacarose, são translocados em plantas (Loescher, 1987). Estes carboidratos variam de gênero para gênero, de espécie para espécie, com a fenologia e mesmo diferentes tecidos de uma mesma planta podem conter e utilizar diferentes carboidratos (Thompson \& Thorpe, 1987; Swedlund \& Locy, 1993).

\subsection{1- Sacarose}

A sacarose é o dissacarídeo mais amplamente encontrado na natureza e a principal forma na qual os carboidratos são transportados na maioria das espécies de plantas e, assim, se assume que este é o melhor carboidrato para a suplementação dos meios de cultura para plantas in vitro (Strickland et al., 1987). É composta por uma molécula de glicose e uma de frutose unidas por ligação glicosídica $\alpha-1,2$. A sacarose não é um açúcar redutor e embora seja extremamente sensivel à hidrólise ácida, ela é quimicamente inerte e altamente solúvel em água (Goodwin \& Mercer, 1983).

Segundo Swedlund \& Locy (1993), a maioria dos estudos da utilização de carboidratos in vitro têm objetivado encontrar uma fonte de carbono que proporcione 
crescimento ótimo. Ainda segundo os autores, na maioria dos casos a sacarose, a glicose e a frutose proporcionam os maiores ganhos em peso das culturas, geralmente com pequenas diferenças entre elas, o que leva a conclusão de que a sacarose é a melhor fonte de carbono a ser usada já que além de proporcionar crescimento ótimo, é uma fonte de custo baixo.

Em cultura de tecidos de membros da família Zingiberaceae, a sacarose tem sido empregada como única fonte de carbono para a suplementação do meio de cultura para a obtenção da organogênese (Babu et al., 1992) e da embriogênese somática (Kackar et al., 1993) em Zinger officinale e da micropropagação em Curcuma amada (Dekkers et al., 1991; Barthakur \& Bordoloi, 1992), em Curcuma domestica (Dekkers et al., 1991), em Zinger officinale (Dogra et al., 1994; Hung, 1995) e em Alpinia purpurata (Illg \& Faria, 1995).

A sacarose tem sido usada também com sucesso para a suplementação do meio de cultura de leguminosas lenhosas na micropropagação de Bauhinia purpurea (Kumar, 1992), de Bauhinia variegala (Mathur \& Mukunthakumar, 1992), de Swartzia madagascariensis (Berger \& Schaffner, 1995), de Bauhinia vahlii (Upreti \& Dhar, 1996) e para a obtenção da organogênese em Populus deltoides (Coleman \& Ernst, 1990), em Dalbergia sissoo (Kumar et al., 1991) e em Sesbania grandiflora (Detrez et al., 1994).

O mesmo efeito foi verificado com leguminosas herbáceas como em culturas de calos (Broetto et al., 1995) e na obtenção da organogênese (Fernandes-Caso et al., 1996; Dillen et al., 1996; Barros et al., 1997) de Phaseolus vulgaris e na obtenção da organogênese e embriogênese somática de Cicer arietinum (Murthy et al., 1996) e de Phaseolus acutifolius, P. aureus, P. coccineus e P. wrightii (Malik \& Saxena, 1992).

\subsection{2- Sorbitol}

O sorbitol, embora presente em algumas espécies de plantas superiores, é encontrado com maior intensidade em espécies da família Rosaceae, Prunoideae e Spiroideae (Zimmermann \& Ziegler, 1975). Em muitas espécies da família Rosaceae 
este é um produto da fotossíntese e também representa cerca de 60 a $90 \%$ do carbono exportado das folhas (Loescher, 1987). Os polióis também atuam na interconversão de açúcares, como agentes redutores, crioprotetores, compostos de reserva e reguladores de coenzimas (Bieleski, 1982).

Segundo Loescher (1987), a sintese de sorbitol em folhas de Prumus armeniaca foi acompanhada pela formação de hexose e poliol fosfato. Outros trabalhos realizados revelaram a presença da aldolase 6-fosfato redutase que catalisa a redução dependente de NADPH da glicose 6-fosfato, formando sorbitol 6-fosfato e NADP. Ainda segundo o autor, além das enzimas sorbitol oxidase que converte sorbitol a glicose e sorbitol desidrogenase dependente de NADP, a enzima sorbitol desidrogenase dependente de NAD foi isolada e caracterizada em tecidos de plantas. Todos os resultados obtidos sugerem que os tecidos fontes, como folhas verdes totalmente expandidas, contêm a aldose 6-fosfato redutase dependente de NADPH, além de uma fosfatase específica que constituem a via de síntese de sorbitol, enquanto que os tecidos dreno possuem a sorbitol desidrogenase dependente de NAD responsável pela oxidação e eventual utilização do sorbitol.

Culturas de calos de Vaccinium corymbosum, cultivados em meio com alta concentração de sais, apresentaram aumento significativo na concentração de açúcares, malato e sorbitol, mostrando que a produção destes compostos para o ajustamento osmótico parece ser um mecanismo fisiológico de adaptação ao estresse salino e hídrico (Muralitharan et al., 1993). Segundo Loescher (1987), pode-se postular um papel para o sorbitol na tolerância contra o estresse porque este atua osmoticamente causando a entrada de água e o balanço das diferenças de pressão osmótica entre o exterior e o interior da célula, por substituir as moléculas de água já que possui grupos $\mathrm{OH}^{-}$como os da água que participam nas interações hidrofóbicas, além de reciclar o excesso de NADPH.

Segundo Kao \& Michayluk (1975), parece que os polióis, de uma maneira geral, podem desempenhar um papel de protetores em células em cultura, tanto através da detoxificação de produtos como auxiliando na manutenção da integridade das membranas. 
O sorbitol não se mostrou uma fonte de carbono eficiente para promover o crescimento in vitro de Syringa e Almus (Welander et al., 1989), Quercus suber (Romano et al., 1995) e Peplis diandra (Samyn, 1995). Este comportamento pode ser explicado pelo fato de que tecidos destas plantas provavelmente não possuem atividade da enzima sorbitol desidrogenase responsável pela degradação de sorbitol (Jain et al., 1997). Ao contrário, este carboidrato que é comumente translocado em membros da família Rosaceae (Zimmermann \& Ziegler, 1975), aumentou a multiplicação in vitro de brotos de Malus (Welander et al., 1989), Prumus cerasus (Borkowska \& Szczerba, 1991) e Prunus armenica (Marino et al., 1993). Já em Prumus mume (Harada \& Murai, 1996), o sorbitol não alterou a taxa de micropropagação obtida com sacarose no meio de cultura. Segundo os autores, os efeitos positivos observados com a utilização do sorbitol não se devem somente a efeitos osmóticos e sim devido ao fato de que este carboidrato é eficientemente metabolizado pelas espécies que compreendem esta familia.

Swedlund \& Locy (1993), estudando culturas de calo de Zea mays suplementadas com sacarose e sorbitol, encontraram atividade da sorbitol desidrogenase em calos embriogênicos crescendo em ambas as fontes de carbono. Calos não embriogênicos apresentavam baixa ou nenhuma atividade desta enzima. Desta forma, o sorbitol é capaz de manter o crescimento apenas de culturas embriogênicas, enquanto em sacarose calos embriogênicos e não embriogênicos crescem. Neste estudo ainda os autores observaram que calos embriogênicos cultivados em sorbitol tinham uma capacidade de regeneração maior do que aqueles cultivados em sacarose.

Frick (1994), estudou o crescimento de culturas de células de algumas espécies da família Lemnaceae em diferentes fontes de carbono, concluindo que não houve diferença marcante no crescimento das culturas em relação a variação da fonte de carbono, mas que as células crescendo em sorbitol apresentavam um contínuo consumo de suas reservas de açúcares redutores, sacarose e amido.

Culturas de protoplastos de Lilium $X$ formolongi cultivadas em sacarose apresentaram crescimento duas vezes superior comparado com o sorbitol. Além disto, em meio suplementado com sorbitol os protoplastos perderam sua capacidade de 
regeneração, mostrando a importância da escolha da fonte de carbono a ser utilizada para a suplementação do meio de cultura de protoplastos (Godo et al., 1996).

Segundo Karhu (1997), o sorbitol embora não tenha causado um aumento na produção de biomassa de plântulas de Malus domestica micropropagadas in vitro, contribuiu para o aumento na indução de brotações axilares. $\mathrm{O}$ mecanismo envolvido no efeito do sorbitol ainda é desconhecido, porém o autor destaca que provavelmente não seria a utilização do carboidrato. Taxas diferentes de absorção e uso da sacarose e do sorbitol proporcionam diferenças na concentração de carboidratos e, consequentemente diferenças no potencial osmótico dos brotos e do meio de cultura. Tem sido proposto que o aumento da concentração de carboidratos em tecidos de plantas age como um fator mensageiro nos eventos da morfogênese e que processos de osmorregulação estariam associados a iniciação de órgãos em plantas (Karhu, 1997). Além disto, outra possibilidade da regulação da morfogênese por carboidratos é pela influência destes no uso de nutrientes, como por exemplo, controlando a atividade de enzimas e através de reações diretas com nutrientes minerais (Karhu, 1997).

Em estudos com Oryza sativa, Tsukahara et al. (1996), concluiram que o sorbitol quando utilizado como única fonte de carbono na suplementação do meio de cultura, age tanto como osmorregulador como também é metabolizado pelas células. Os autores ainda destacam que este papel duplo do sorbitol é essencial para promover a regeneração in vitro desta espécie.

Segundo Jain et al. (1997), há uma correlação entre o conteúdo de água de calos de Oryza sativa e sua habilidade de regenerar plantas. Em seus estudos, os autores concluíram que o sorbitol agia principalmente como regulador osmótico e ao contrário do que ocorre com a sacarose, este não promove crescimento in vitro e nem é metabolizado pela maioria das plantas superiores. Várias hipóteses levantadas pelos autores sugerem que o estresse osmótico, causado pela adição de sorbitol, pode causar uma ruptura das conecções dos plasmodesmatas entre as células, tornando-as isoladas fisiologicamente e possibilitando a diferenciação de um maior número de células. Além disto, plantas sob estresse hídrico possuem uma maior concentração de ABA, também conhecido como hormônio que estimula a embriogênese somática. 


\subsection{3- Galactose}

A galactose, um constituinte comum de muitas substâncias poliméricas em plantas, pode ser metabolicamente liberada de suas várias combinações e então reutilizada como fonte de carbono. Ela não é geralmente encontrada na forma livre na natureza e não se sabe se ocorre nesta forma em plantas, porém sua conversão para galactose 1-fosfato e depois para uridina difosfato galactose pode ocorrer rapidamente. A galactose adicionada exogenamente em baixas concentrações a tecidos de plantas é incorporada como constituinte da parede celular ou convertida a sacarose (Figura 2).

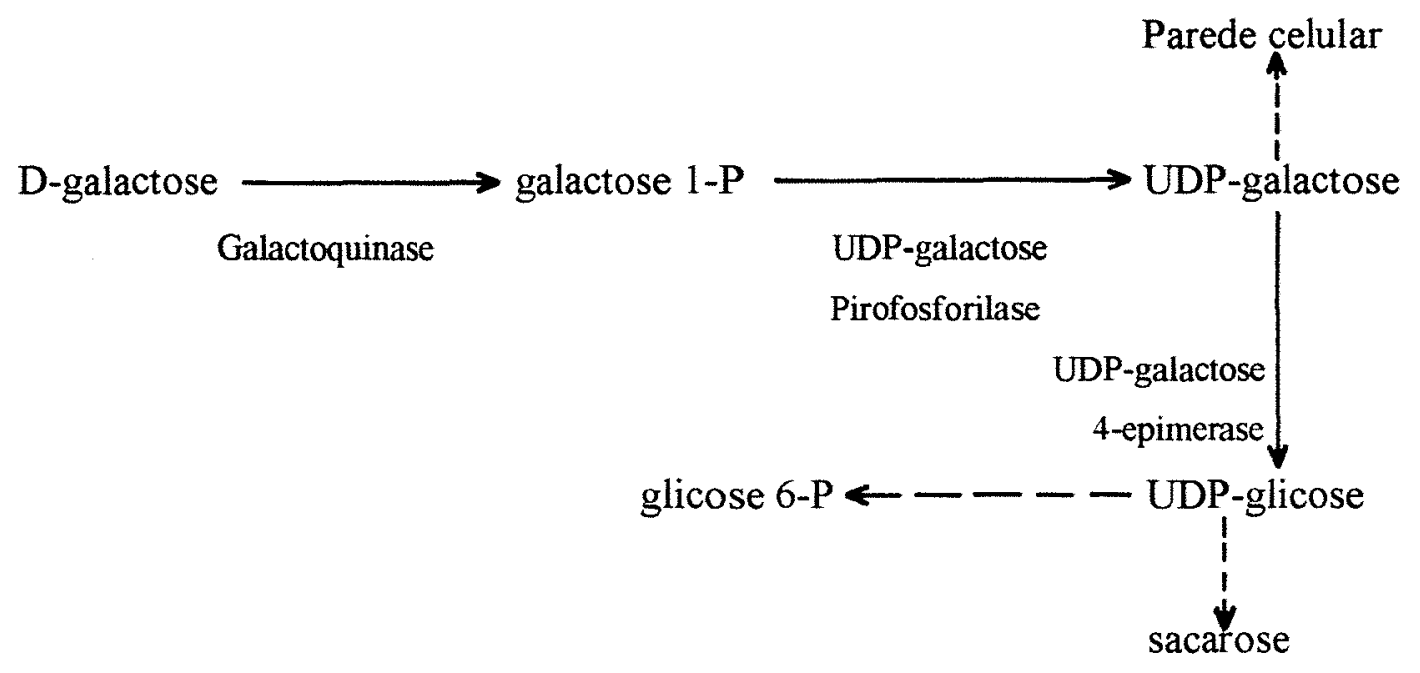

Figura 2: Incorporação da galactose como constituinte da parede celular ou utilização para a síntese de sacarose.

Segundo Maretzki \& Thom (1978), em uma população de células de Saccharum sp. adaptadas ao crescimento em galactose, a UDP-gal 4-epimerase parece ser a enzima chave para a formação dos intermediários glicolíticos a partir da galactose. A ausência de atividade da gal-P uridiltransferase dá suporte à suposição de que D-galactose é transformada em galactose 1-P pela galactoquinase e posteriormente a UDP-galactose pela ação da enzima UDP-gal pirofosforilase. UDP-gal pode ser utilizada na síntese da 
parede celular ou entrar na via glicolítica sendo transformada pela UDP-gal 4-epimerase a UDP-glicose, que é posteriormente convertida a glicose 1-P e glicose 6-P pelas enzimas UDP-glicose pirofosforilase e fosfoglicomutase, respectivamente.

Por sua vez, a galactose adicionada em concentrações superiores a $5 \mathrm{mM}$, é freqüentemente tóxiça às plantas. A causa exata desta toxidez ainda não é conhecida. Sabe-se que a galactose e seus metabólitos participam de processos como a síntese de parede celular, expansão celular, possivelmente por regulação do tipo retroinibição, além de promover a evolução de etileno dependente de auxina, a qual tem sido sugerido como a causa para os sintomas de toxidez (Maretzki \& Thom, 1978).

A galactose, quando utilizada como única fonte de carbono no meio de cultura, não promoveu crescimento de células em suspensão de Dioscorea deltoidea (Rokem et al., 1985) e de culturas de calos de Zea mays (Swedlund \& Locy, 1993).

Culturas de células em suspensão de Picrasma quassioides crescendo em meio de cultura contendo galactose como fonte de carbono tiveram um crescimento $20 \%$ superior quando comparadas com aquelas crescendo em sacarose (Scragg \& Allan, 1986). Porém, em culturas de células de algumas espécies da familia Lemnaceae, não houve diferença marcante no crescimento em função da fonte de carbono, embora as células crescendo em galactose apresentassem contínuo consumo de suas reservas de açúcares redutores, sacarose e amido (Frick, 1994).

Estudando o crescimento de culturas de células em suspensão de Beta vulgaris, Monroy et al. (1994) concluíram que as culturas mantidas em sacarose como fonte de carbono tinham um crescimento seis vezes superior e eram duas vezes mais eficientes em usar a fonte de carbono do que aquelas mantidas em galactose.

Segundo Samyn (1995), a galactose utilizada como fonte alternativa de carbono para o crescimento de células em suspensão de Peplis diandra permitiu um crescimento comparável ao da sacarose. Quando utilizada na concentração de 5\%, a galactose condicionou produção máxima de biomassa, conferindo um crescimento superior à sacarose.

Calos de Lemna minor crescendo em sacarose se adaptam de maneira fácil, rápida e reversível à galactose como fonte de carbono (Frick \& Morley, 1995). O extrato 
destes calos mostram altas atividades específicas das enzimas ß-galactosidase, galactoquinase, UDP-galactose pirofosforilase e pirofosforilase inorgânica, todas envolvidas no metabolismo da galactose.

Culturas de células em suspensão de Citrus deliciosa suplementadas com sacarose cresceram três vezes mais do que aquelas com galactose. Entretanto, na superficie dos microcalos crescendo em galactose podia-se visualizar a formação de embriões somáticos após 18 dias de cultura (Cabasson et al., 1995).

A galactose tem sido empregada com sucesso para a obtenção da embriogênese somática em algumas espécies, como é o caso de Citrus (Lorenzo et al., 1994; Cabasson et al., 1995), Abies alba (Schuller \& Reuther, 1993), Triticum aestivum (Navarro, 1994) e Rosa rugosa (Kunitake et al., 1993). Em vista disto, muitas hipóteses foram propostas para explicar o efeito da galactose na indução da embriogênese somática. Segundo Cabasson et al. (1995), estes estudos incluem a inibição da biossintese e transporte de auxina, alterando assim o balanço endógeno deste hormônio e o estímulo da biossintese de etileno, principalmente em sinergismo com a auxina, pois é sabido que o etileno está relacionado com indução de embriogênese somática.

Segundo Lemos \& Blake (1996 a,b), embora a galactose seja um constituinte comum de muitas substâncias poliméricas e o principal componente de vários açúcares presentes em pequenas quantidades na seiva do floema de muitas plantas, alguns trabalhos têm identificado este monossacarídeo como sendo tóxico ou inibidor do enraizamento. A resposta ao enraizamento de explantes maturos de Annona muricata foi melhorada quando a galactose foi empregada como fonte de carbono no meio de cultura.

\subsection{4- Glicerol}

Segundo Lehninger et al. (1993), o glicerol é um açúcar alcoólico que ocorre em abundância na natureza pois é um importante componente da maioria dos lipídeos. Ainda segundo os autores, glicerol e glicerol 3-fosfato, os quais são derivados de triacilgliceróis e fosfoglicerídeos, respectivamente, também podem entrar na sequeencia glicolítica através da via de formação e degradação do glicerol. O glicerol livre é 
fosforilado com gasto de ATP pela glicerolquinase formando glicerol 3-fosfato que é oxidado a dihidroxi acetona fosfato pela glicerolfosfato desidrogenase, presente no citoplasma, que requer NAD como aceptora de elétrons, ou pela glicerofosfato desidrogenase mitocondrial, uma flavoproteína. A dihidroxi acetona fosfato formada é então enzimaticamente convertida à gliceraldeído 3-fosfato e entra no estágio secundário da glicólise. Segundo Beevers (1980), a maior parte do glicerol originário da hidrólise dos glicerídeos é convertida em sacarose envolvendo as reações da gliconeogênese.

Cultura de células em suspensão de Acer pseudoplatamus mantidas em meio de cultura suplementado com glicerol como única fonte de carbono, apresentaram crescimento mais lento avaliado pelo número de células, peso seco e volume de agregados celulares, quando comparadas com aquelas crescendo em glicose (Grout et al., 1976). Devido à produção máxima de biomassa de ambas as culturas serem comparáveis em termos de peso seco, os autores concluíram que a via metabólica de utilização do glicerol era ativa e podia manter níveis adequados de síntese dos compostos necessários para o crescimento e manutenção da cultura e produção de energia intracelular.

Segundo Roberts \& Baba (1982), o glicerol não se mostrou uma fonte de carbono eficiente para suportar o crescimento de calos de Lactuca sativa embora promovesse a formação de elementos traqueais de xilema após 9 dias de cultura. Por outro lado, em Citrus, o glicerol não mostrou bons resultados quanto a diferenciação de elementos traqueais (Kahn, 1995).

Sabe-se que o glicerol estimula a embriogênese somática em espécies de Citrus (Deng et al., 1991; Singh et al., 1992; Gavish et al., 1992; Spiegel-Roy \& Saad, 1997) e Cichorium (Robatche-Claive et al., 1992; Couillerot et al., 1993; Helleboid et al., 1995), porém o mesmo não acontece com Medicago sativa, onde a substituição da sacarose por glicerol parece não causar nenhum efeito no processo de diferenciação das células in vitro (Strickland et al., 1987).

Vu et al. $(1993,1995)$, concluíram que cultura de células em suspensão de Citrus sinensis cultivadas em glicerol, embora apresentassem crescimento expresso em matéria fresca duas vezes menor do que células crescendo em sacarose, sua concentração 
protéica era duas vezes maior do que as das células crescendo em sacarose e que a embriogênese somática só ocorria em glicerol como fonte de carbono. 


\section{3- MATERIAL E MÉTODOS}

\section{1- Meio básico de cultura}

A composição básica dos meios de cultura utilizados em todos os experimentos foi aquela contendo total ou metade da concentração dos sais e vitaminas de Murashige e Skoog (1962) (Tabela 1), solidificado (meio sólido) ou não (meio líquido) com 2,3g/L de Phytagel (Sigma) e suplementados com fitorreguladores apropriados e a fonte de carbono em estudo em concentração similar a de sacarose sugerida por Murashige e Skoog (1962).

\section{2- Bauhinia forficata Link}

\subsection{1- Germinação de embriões}

As sementes foram desinfestadas em solução de hipoclorito de sódio comercial (Q-Boa) a $20 \%(\mathrm{v} / \mathrm{v})$ por 15 minutos e em solução de etanol $70 \%(\mathrm{v} / \mathrm{v})$ por 3 minutos. Em condições assépticas, depois de desinfestadas, as sementes foram lavadas 3 vezes em água destilada autoclavada e os embriões foram retirados e inoculados em meio de cultura para germinação (Carvalho, 1998).

O meio de cultura utilizado para a germinação dos embriões era composto por metade da concentração dos sais básicos e vitaminas de Murashige \& Skoog (1962), suplementado com $30 \mathrm{~g} / \mathrm{L}$ de sacarose, solidificado com $2,3 \mathrm{~g} / \mathrm{L}$ de Phytagel (Sigma) e o pH 5,7 ajustado com $\mathrm{KOH} 1 \mathrm{~N}$ antes da autoclavagem a $120^{\circ} \mathrm{C}$ por 30 minutos. Os frascos utilizados foram tubos de ensaio de $60 \mathrm{~mL}$ fechados com papel aluminio. As 
culturas foram mantidas em sala de crescimento sob condições de fotoperíodo de 16/8 horas (claro/escuro) provido por lâmpadas fluorescentes que forneciam uma radiação fotossinteticamente ativa de $50,8 \pm 6,6 \mu \mathrm{mol} \cdot \mathrm{m}^{-2} \cdot \mathrm{s}^{-1}$ a $30 \mathrm{~cm}$ das culturas, medido com sensor quântico modelo Li-250 (Li-Cor) e temperatura de $25 \pm 2^{\circ} \mathrm{C}$ (Carvalho, 1998).

Tabela 1: Sais e vitaminas componentes do meio básico de Murashige e Skoog (1962).

\begin{tabular}{|c|c|}
\hline COMPONENTES & CONCENTRAÇĀO $(\mathrm{mg} / \mathrm{L})$ \\
\hline $\mathrm{NH}_{4} \mathrm{NO}_{3}$ & 1650 \\
\hline $\mathrm{KNO}_{3}$ & 1900 \\
\hline $\mathrm{CaCl}_{2} \cdot 2 \mathrm{H}_{2} \mathrm{O}$ & 440 \\
\hline $\mathrm{MgSO}_{4} .7 \mathrm{H}_{2} \mathrm{O}$ & 370 \\
\hline $\mathrm{KH}_{2} \mathrm{PO}_{4}$ & 170 \\
\hline $\mathrm{Na}_{2}$ EDTA & 37,3 \\
\hline $\mathrm{FeSO}_{4} .7 \mathrm{H}_{2} \mathrm{O}$ & 27,8 \\
\hline $\mathrm{H}_{3} \mathrm{BO}_{3}$ & 6,2 \\
\hline $\mathrm{MnSO}_{4} \cdot 4 \mathrm{H}_{2} \mathrm{O}$ & 22,3 \\
\hline $\mathrm{ZnSO}_{4} \cdot 4 \mathrm{H}_{2} \mathrm{O}$ & 8,6 \\
\hline $\mathrm{KI}$ & 0,83 \\
\hline $\mathrm{Na}_{2} \mathrm{MoO}_{4} \cdot 2 \mathrm{H}_{2} \mathrm{O}$ & 0,25 \\
\hline $\mathrm{CuSO}_{4} .5 \mathrm{H}_{2} \mathrm{O}$ & 0,025 \\
\hline $\mathrm{CoCl}_{2} .6 \mathrm{H}_{2} \mathrm{O}$ & 0,025 \\
\hline \multicolumn{2}{|l|}{ VITAMINAS } \\
\hline Ácido nicotínico & 0,5 \\
\hline Tiamina & 1,0 \\
\hline Piridoxina & 0,5 \\
\hline Glicina & 3,0 \\
\hline I-inositol & 100 \\
\hline
\end{tabular}

\subsection{2- Estabelecimento da cultura de calos}

Os hipocótilos das plântulas oriundas dos embriões 40 dias após a germinação in vitro, foram utilizados como explantes para o início da cultura de calos. Os explantes de aproximadamente $1 \mathrm{~cm}$ de comprimento, foram inoculados em meio de cultura contendo a metade da concentração dos sais básicos e vitaminas de Murashige \& Skoog (1962), suplementado com $30 \mathrm{~g} / \mathrm{L}$ de sacarose e $4,0 \mathrm{mg} / \mathrm{L}$ de $\mathrm{BAP}$, solidificado com $2,3 \mathrm{~g} / \mathrm{L}$ de 
Phytagel (Sigma) e o pH 5,7 ajustado com $\mathrm{KOH} 1 \mathrm{~N}$ antes de ser autoclavado a $120^{\circ} \mathrm{C}$ por 30 minutos. Os frascos utilizados foram tubos de dieta de $30 \mathrm{~mL}$ fechados com papel alumínio. As culturas foram mantidas em sala de crescimento sob as mesmas condições descritas acima para a germinação dos embriões (Carvalho, 1998).

\subsection{3- Estabelecimento da cultura de células em suspensão}

Após 60 dias de cultivo, os calos produzidos a partir de hipocótilo foram separados dos explantes, desintegrados em pequenos aglomerados e $5 \mathrm{~g}$ de calos foram transferidos para $100 \mathrm{~mL}$ de meio de cultura líquido de mesma composição em erlemmeyers de $250 \mathrm{~mL}$ e mantidos sob agitação $(60 \mathrm{rpm})$ e mesmas condições de cultivo para a devida adaptação das células. Foram realizadas transferências a cada 20 dias de cultivo.

\section{3- Curcuma zedoaria Roscoe}

\subsection{1- Estabelecimento da cultura de calos}

Para o estabelecimento da cultura de calos de Curcuma zedoaria Roscoe, foram utilizados segmentos radiculares de $1 \mathrm{~cm}$ de comprimento isolados de plântulas micropropagadas in vitro, a partir de cultura de ápices. $\mathrm{O}$ meio de cultura de micropropagação era composto pelos sais básicos e vitaminas de Murashige \& Skoog (1962), suplementado com 30g/L de sacarose e 2,0mg/L de BAP (Miachir, 1992).

A cultura de calos foi iniciada com a inoculação dos explantes em meio de cultura contendo os sais básicos e vitaminas de Murashige \& Skoog (1962), suplementado com $30 \mathrm{~g} / \mathrm{L}$ de sacarose, $2,5 \mathrm{mg} / \mathrm{L}$ de NAA e $0,5 \mathrm{mg} / \mathrm{L}$ de BAP, solidificado com 2,3g/L de Phytagel (Sigma) e o pH 5,7 ajustado com KOH $1 \mathrm{~N}$ antes da autoclavagem a $120^{\circ} \mathrm{C}$ por 30 minutos. Os frascos utilizados foram tubos de dieta de $30 \mathrm{~mL}$ fechados com papel alumínio. As culturas foram mantidas em sala de crescimento no escuro e à temperatura de $25 \pm 2^{\circ} \mathrm{C}$ (Miachir, 1992). 


\subsection{2- Estabelecimento da cultura de células em suspensão}

Após 120 dias de cultivo, os calos produzidos à partir de segmentos radiculares foram separados dos explantes, desintegrados em pequenos aglomerados e $5 \mathrm{~g}$ de calos foram transferidos para $100 \mathrm{~mL}$ de meio de cultura líquido de mesma composição em erlemmeyers de $250 \mathrm{~mL}$ e mantidos sob agitação $(60 \mathrm{rpm})$ e mesmas condições de cultivo para a devida adaptação das células. Foram realizadas transferências a cada 20 dias de cultivo.

\section{4- Phaseolus vulgaris}

\subsection{1- Estabelecimento da cultura de calos}

Embriões maduros foram retirados de sementes desinfestadas em solução de hipoclorito de sódio comercial (Q-Boa) a $20 \%$ (v/v) por 20 minutos e em solução de etanol $70 \%(\mathrm{v} / \mathrm{v})$ por 1 minuto. Lavou-se as sementes 3 vezes em água destilada autoclavada, em câmara asséptica. Os embriões, ainda em condições assépticas, foram retirados e inoculados em meio de cultura contendo os sais básicos e vitaminas de Murashige e Skoog (1962), suplementado com 5,0mg/L de 2,4-D, 30g/L de sacarose, solidificado com 2,3g/L de Phytagel (Sigma) e o pH 5,7 ajustado com KOH $1 \mathrm{~N}$ antes da autoclavagem a $120^{\circ} \mathrm{C}$ por 30 minutos. Os frascos utilizados foram tubos de dieta de $30 \mathrm{~mL}$ fechados com papel alumínio. As culturas foram mantidas em sala de crescimento sob condições de fotoperíodo de 16/8 horas (claro/escuro) provido por lâmpadas fluorescentes que forneciam uma radiação fotossinteticamente ativa de 50,8 $\pm 6,6 \mu \mathrm{mol} \cdot \mathrm{m}^{-2} \cdot \mathrm{s}^{-1}$ a $30 \mathrm{~cm}$ das culturas, medido com sensor quântico modelo Li-250 (LiCor) e temperatura de $25 \pm 2^{\circ} \mathrm{C}$ (Gallo, 1994). 


\subsection{2- Estabelecimento da cultura de células em suspensão}

Após 60 dias em meio de cultura, os calos produzidos à partir dos embrião inoculados foram separados dos explantes, desintegrados em pequenos aglomerados e $5 \mathrm{~g}$ de calos foram transferidos para $100 \mathrm{~mL}$ de meio de cultura líquido contendo os sais básicos e vitaminas de Murashige e Skoog (1962), suplementado com 2.0mg/L de 2,4-D, $30 \mathrm{~g} / \mathrm{L}$ de sacarose e $\mathrm{pH} 5,7$ ajustado com $\mathrm{KOH} 1 \mathrm{~N}$ antes da autoclavagem a $120^{\circ} \mathrm{C}$ por 30 minutos. Os frascos utilizados foram erlemmeyers de $250 \mathrm{~mL}$, mantidos sob agitação (60 rpm) e mesmas condições de cultivo para a devida adaptação das células. Transferências periódicas foram realizadas a cada 20 dias de cultivo.

\section{5- Teste do efeito de diferentes fontes de carbono}

A fim de se testar o efeito de diferentes fontes de carbono nas culturas de células em suspensão de plantas, as culturas de cada espécie depois de adaptadas, foram transferidas para meio de cultura líquido de mesma composição de sais, vitaminas (meio MS) e fitorreguladores, mas diferindo quanto a fonte de carbono. Foram transferidos $0,5 \mathrm{~g}$ de células (peso fresco) para erlemmeyers de $125 \mathrm{~mL}$ contendo $50 \mathrm{~mL}$ de meio de cultura suplementado com $30 \mathrm{~g} / \mathrm{L}$ de sacarose ou $60 \mathrm{~g} / \mathrm{L}$ de galactose ou $60 \mathrm{~g} / \mathrm{L}$ de sorbitol ou $120 \mathrm{~g} / \mathrm{L}$ de glicerol, embora estas concentrações sejam citadas na literatura como tóxicas para células de algumas plantas, a nossa preocupação foi a de fornecer a mesma concentração de carbono em todos os tratamentos. Cada carboidrato foi considerado um tratamento e cada tratamento era constituído de 10 frascos correspondente aos dias de amostragem $0,5,10,15,20,25,30,35,40$ e 45, para avaliação do crescimento celular. Assim, ao todo, foram realizadas quatro repetições, cada repetição correspondendo a um bloco. O bloco, por sua vez, era constituído de todos os tratamentos em todos os dias (num total de 10) de análise. 


\section{6- Estudo do ganho de biomassa}

$\mathrm{O}$ crescimento celular foi avaliado com base em dois parâmetros: massa fresca $\mathrm{e}$ massa seca em gramas. Em cada dia de análise de crescimento $(0,5,10,15,20,25,30$, 35,40 e 45 dias), um frasco de cada tratamento foi filtrado a vácuo em papel Whatman número 1 e as células retidas no papel foram pesadas a fim de se avaliar a massa fresca das culturas. Após liofilização por 24 horas, as células foram novamente pesadas para se avaliar a massa seca. $\mathrm{A}$ taxa de crescimento absoluto médio ( $\triangle \mathrm{PSt}$ ) foi determinada pela eq. (1) e o aumento de massa fresca ( $\triangle \mathrm{PFt}$ ) das culturas foi avaliada segundo a eq. (2).

$$
\begin{aligned}
& \Delta \mathrm{PSt}=\mathrm{PSt}-\mathrm{PSo} \\
& \Delta \mathrm{PFt}=\mathrm{PFt}-\mathrm{PFo}
\end{aligned}
$$

onde: $\mathrm{PSt}=$ massa seca no tempo $\mathrm{t}$

PSo = massa seca inicial

$\mathrm{t}=$ tempo em dias correspondente ao ponto de inflexão da curva de crescimento

$\mathrm{PFt}=$ massa fresca no tempo $\mathrm{t}$

$\mathrm{PFO}=$ massa fresca inicial

\section{7- Preparo do extrato para análise da atividade enzimática}

Para a análise das atividades enzimáticas e concentração protéica, amostras de $0,04 \mathrm{~g}$ de células em suspensão liofilizadas foram colocadas em almofariz, congeladas em nitrogênio líquido e trituradas em presença de $2 \mathrm{~mL}$ de tampão extrator contendo HEPES/NaOH $200 \mathrm{mM}$ pH7.5, EDTA.Naz $20 \mathrm{mM}$, DTT $1 \mathrm{mM}$, acetato de magnésio $10 \mathrm{mM}$ e PVP $10 \%$, para dar início ao processo de extração. Depois de macerada em tampão extrator, as amostras foram centrifugadas a $10.000 \times \mathrm{xG}$ por 20 minutos a $4^{\circ} \mathrm{C} \mathrm{em}$ centrífuga Eppendorf modelo 5403. Após centrifugação e descarte do precipitado foi 
aproveitado e medido o volume do sobrenadante que foi utilizado como fonte de enzimas.

\section{8- Análise da atividade enzimática}

As atividades de todas as enzimas foram avaliadas pelo monitoramento da oxidação/redução do $\mathrm{NAD}(\mathrm{P}) \mathrm{H}$ / $\mathrm{NAD}(\mathrm{P})$ espectrofotometricamente a $340 \mathrm{~nm}$ (Espectrofotômetro U-3210, Hitachi). As análises foram conduzidas a $25^{\circ} \mathrm{C}$ num volume final de reação de $1 \mathrm{~mL}$. As atividades foram determinadas sob condições de saturação de substrato e pH ótimo. As misturas de reações foram inicialmente incubadas pelo menos por 3 minutos para se observar a apropriada estabilização antes da adição do composto que desencadearia a reação.

\subsection{1-sacarose sintase (UDP-glicose: D-frutose 2-glicosiltransferase, EC 2.4.1.13)}

A mistura de reação continha num volume final de $1 \mathrm{~mL}$ : tampão NAD (HEPES/ $\mathrm{NaOH} 100 \mathrm{mM} \mathrm{pH} 7.5$; acetato $\mathrm{Mg} 3 \mathrm{mM}$; DTT $5 \mathrm{mM}$; glicose 1,6 bisfosfato $0.02 \mathrm{mM}$; NAD 0.5mM), sacarose $100 \mathrm{mM}$, UDP 0,5mM, PPi $1 \mathrm{mM}, 2$ unidades de fosfoglicomutase e 2 unidades de glicose 6-fosfato desidrogenase. A reação, representada pela equação abaixo, foi iniciada pela adição da mistura de sacarose, $\cdot$ UDP e PPi (Sung et al., 1989).

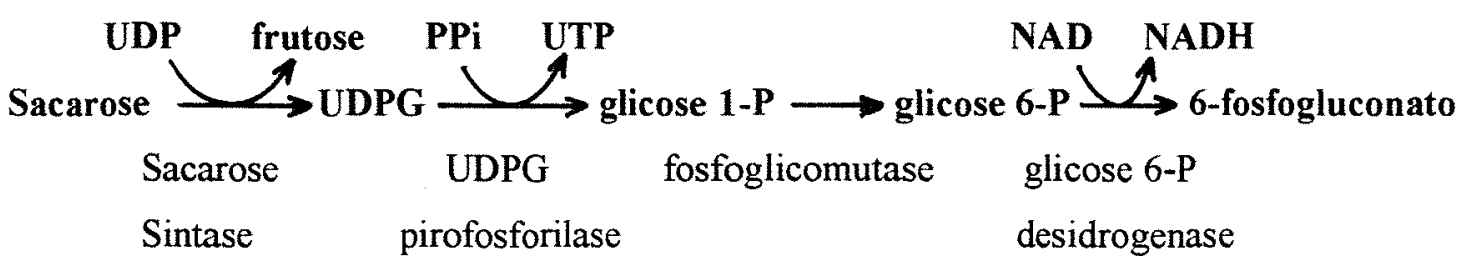


3.8.2-uridina difosfato glicose pirofosforilase (UTP: D-glicose 1-fosfato uridiltransferase, EC 2.7.7.9)

A mistura de reação continha num volume final de $1 \mathrm{~mL}$ : tampão NAD (HEPES/NaOH 100mM pH7.5; acetato Mg 3mM; DTT $5 \mathrm{mM}$; glicose 1,6 bisfosfato $0.02 \mathrm{mM}$; NAD 0.5mM), UDPG $1 \mathrm{mM}$, PPi $1 \mathrm{mM}, 2$ unidades de fosfoglicomutase e 2 unidades de glicose 6-fosfato desidrogenase. A reação, representada pela equação abaixo, foi iniciada pela adição do PPi (Huber \& Akazawa, 1986).

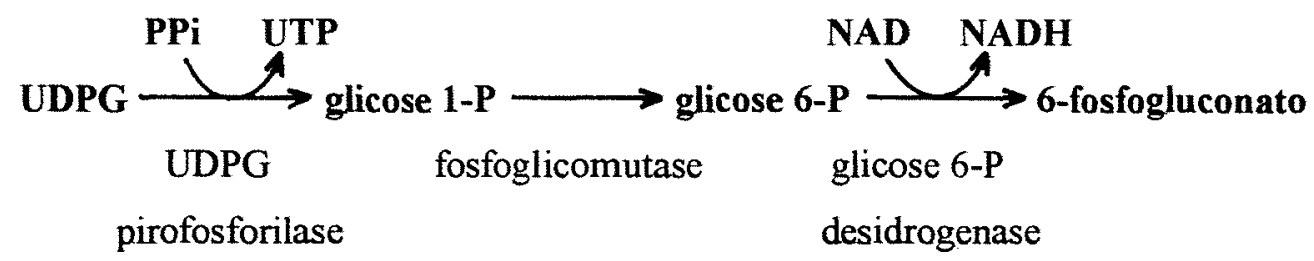

\subsection{3- frutoquinase (EC 2.7.1.4)}

A mistura de reação continha num volume final de $1 \mathrm{~mL}$ : tampão NAD (HEPES/NaOH 100mM pH8.0; acetato Mg 3mM; DTT $5 \mathrm{mM}$; glicose 1,6 bisfosfato $0.02 \mathrm{mM}$; NAD 0.5mM), frutose 0,5mM, ATP ou UTP $1 \mathrm{mM}, 2$ unidades de glicose 6fosfato desidrogenase e 2 unidades de fosfoglicose isomerase. A reação, representada pela equação abaixo, foi iniciada pela adição do ATP (Huber \& Akazawa, 1986).

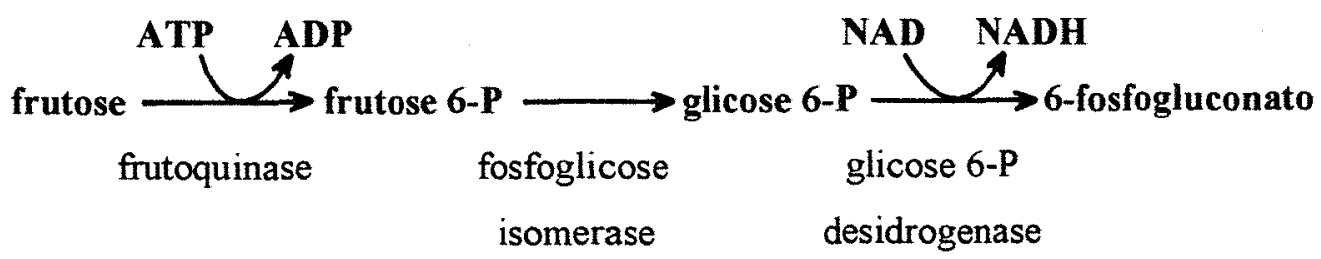




\subsection{4- glicoquinase (EC 2.7.1.2)}

A mistura de reação continha num volume final de $1 \mathrm{~mL}$ : tampão NAD (HEPES/ $\mathrm{NaOH} 100 \mathrm{mM}$ pH8.0; acetato $\mathrm{Mg} 3 \mathrm{mM}$; DTT $5 \mathrm{mM}$; glicose 1,6 bisfosfato $0.02 \mathrm{mM}$; NAD $0.5 \mathrm{mM}$ ), glicose $5 \mathrm{mM}$, ATP $1 \mathrm{mM}$ e 2 unidades de glicose 6 -fosfato desidrogenase. A reação, representada pela equação abaixo, foi iniciada pela adição do ATP (Huber \& Akazawa, 1986- modificado).

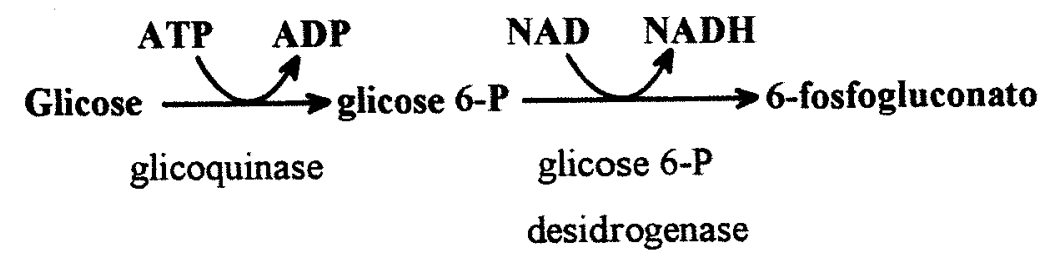

3.8.5-fosfofrutoquinase dependente de PPi (pirofosfato: D-frutose 6-fosfato 1fosfotransferase, EC 2.7.1.90)

A mistura de reação continha num volume final de $1 \mathrm{~mL}$ : tampão NADH (HEPES/NaOH 100mM pH7.5; acetato $\mathrm{Mg} 3 \mathrm{mM}$; DTT 5mM; NADH 0.3mM), frutose 6-fosfato $10 \mathrm{mM}$, frutose 2,6-bisfosfato $2 \mu \mathrm{M}$, PPi $1 \mathrm{mM}, 0,6$ unidades de aldolase, 14 unidades de triose fosfato-isomerase e 2 unidades de glicerol 3-fosfato desidrogenase. A reação, representada pela equação abaixo, foi iniciada pela adição do PPi (Xu et al., 1986).

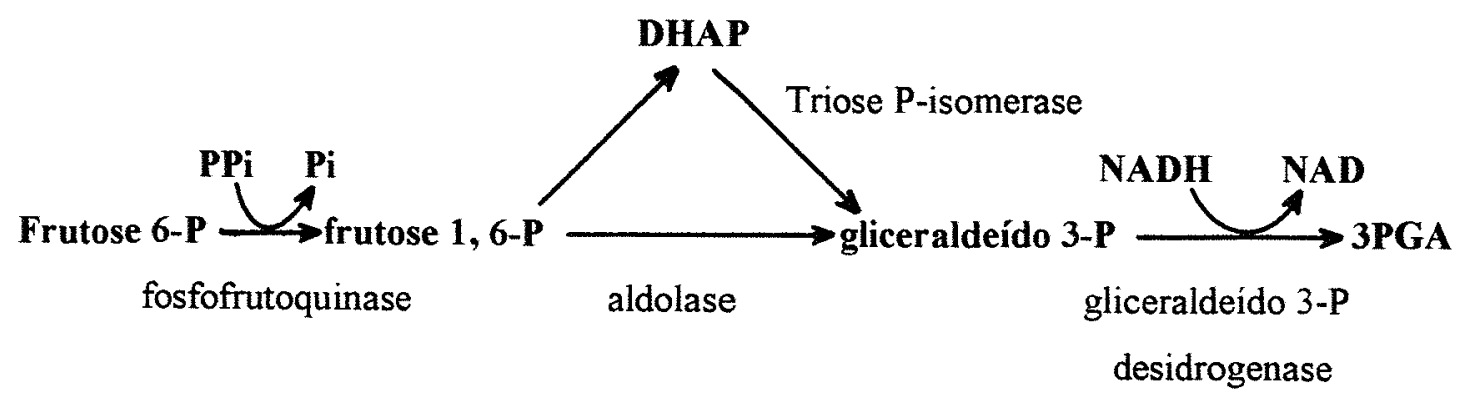


3.8.6-fosfofrutoquinase dependente de ATP ou UTP (ATP: D-frutose 6-fosfato 1fosfotransferase EC2.7.1.11)

A mistura de reação continha num volume final de $1 \mathrm{~mL}$ : tampão $\mathrm{NADH}$ (HEPES/NaOH 100mM pH7.5; acetato $\mathrm{Mg} 3 \mathrm{mM}$; DTT 5mM; NADH 0.3mM), frutose 6-fosfato $10 \mathrm{mM}$, ATP ou UTP $1 \mathrm{mM}, 0,6$ unidades de aldolase, 14 unidades de triose fosfato-isomerase e 2 unidades de glicerol 3-fosfato desidrogenase. A reação, representada pela equação abaixo, foi iniciada pela adição do ATP (Sung et al., 1989).

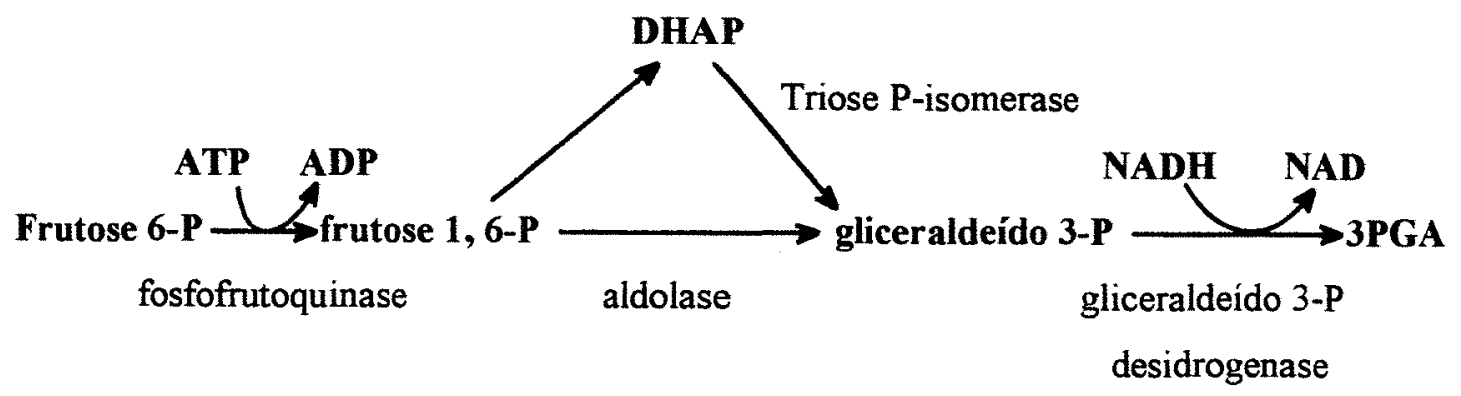

\subsection{7- frutose 1,6-bisfosfatase}

A mistura de reação continha num volume final de $1 \mathrm{~mL}$ : tampão Tricine $100 \mathrm{mM}$ pH 8.8, frutose 1,6-bisfosfato $1 \mathrm{mM}$, EDTA. $\mathrm{Na}_{2} 1,2 \%$, acetato de magnésio $5 \mathrm{mM}$, ADP $1 \mathrm{mM}, 6$ unidades de glicose 6-fosfato desidrogenase e 3 unidades de fosfoglicose isomerase. A reação, representada pela equação abaixo, foi iniciada pela adição do ADP (Racker, 1962).

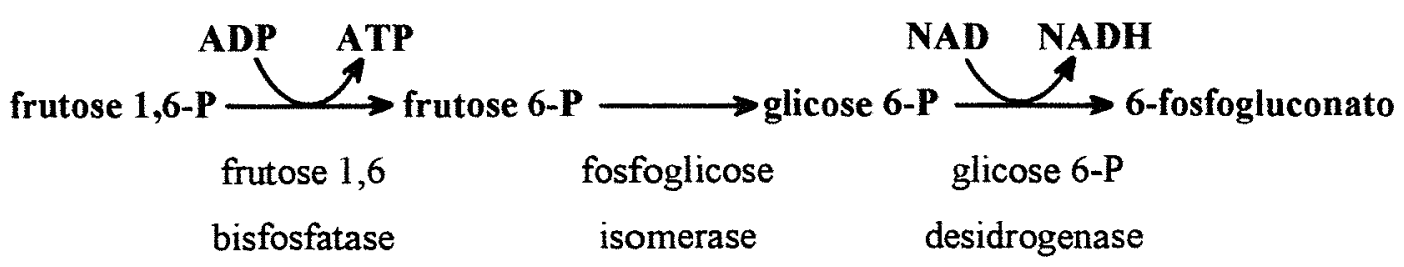




\subsection{8- Invertase ácida (EC 3.2.1.26)}

A mistura de reação continha num volume final de $1 \mathrm{~mL}$ : tampão de incubação ácido $\left(\mathrm{K}_{2} \mathrm{HPO}_{4} 70 \mathrm{mM}\right.$; ácido cítrico $40 \mathrm{mM}$; pH 5.0) e sacarose $25 \mathrm{mM}$, foi incubada por 15 minutos a $25^{\circ} \mathrm{C}$. Após a paralisação da reação por fervura, foi adicionado $\mathrm{NaOH}$ para trazer o pH da solução de reação para 7.5, tampão NAD (HEPES/NaOH 100mM pH7.5; acetato $\mathrm{Mg} 3 \mathrm{mM}$; DTT $5 \mathrm{mM}$; NAD 0.5mM), ATP $1 \mathrm{mM}, 2$ unidades de hexoquinase e 2 unidades de glicose 6-fosfato desidrogenase. A reação, representada pela equação abaixo, foi iniciada pela adição do ATP (Xu et al., 1989).

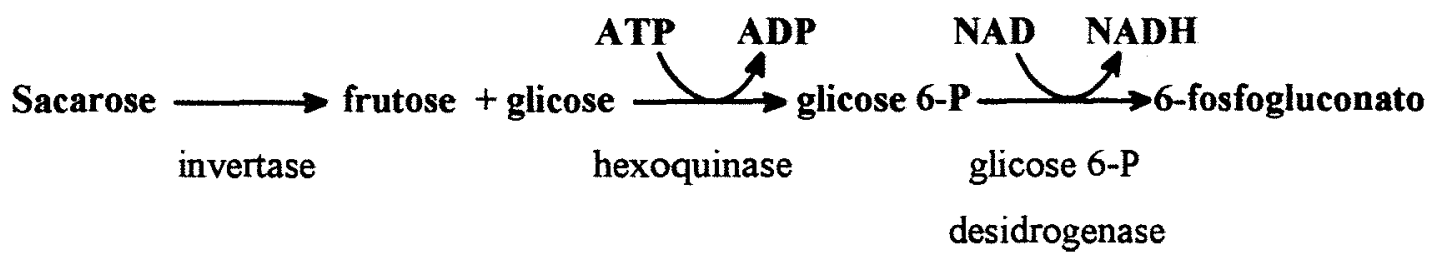

\subsection{9- Invertase neutra (EC 3.2.1.26)}

A mistura de reação continha num volume final de $1 \mathrm{~mL}$ : tampão de incubação neutro $\left(\mathrm{K}_{2} \mathrm{HPO}_{4} 160 \mathrm{mM}\right.$; ácido cítrico $\left.20 \mathrm{mM} ; \mathrm{pH} 7.0\right)$ e sacarose $100 \mathrm{mM}$, foi incubada por 15 minutos a $25^{\circ} \mathrm{C}$. Após a paralisação da reação por fervura, foi adicionado tampão NAD (HEPES/NaOH 100mM pH7.5; acetato $\mathrm{Mg} 3 \mathrm{mM}$; DTT 5mM; NAD 0.5mM), ATP $1 \mathrm{mM}, 2$ unidades de hexoquinase e 2 unidades de glicose 6-fosfato desidrogenase. A reação, representada pela equação abaixo, foi iniciada pela adição do ATP (Xu et al., 1989).

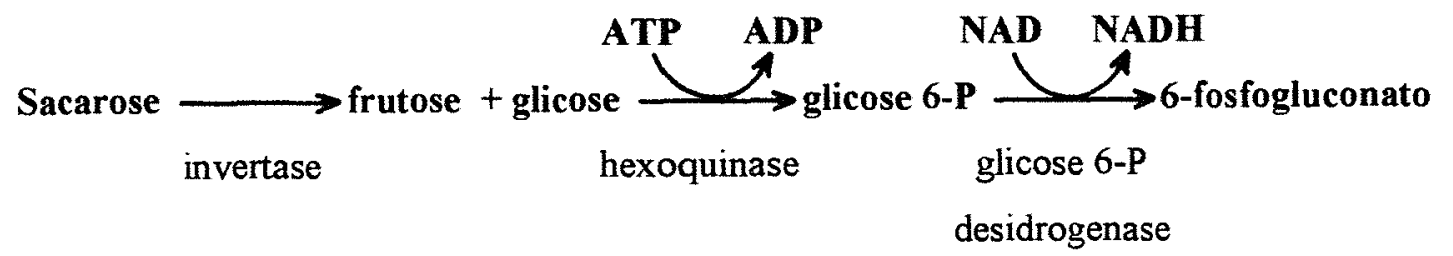


3.8.10- sorbitol desidrogenase NAD-dependente (poliol: NAD 5-oxidoredutase, EC 1.1.1.14)

A mistura de reação continha num volume final de $1 \mathrm{~mL}$ : tampão Tricine $50 \mathrm{mM}$ pH 8.5 , acetato de magnésio $5 \mathrm{mM}$ e sorbitol $80 \mathrm{mM}$. A reação, representada pela equação abaixo, foi iniciada pela adição do sorbitol (Doehlert et al., 1988).

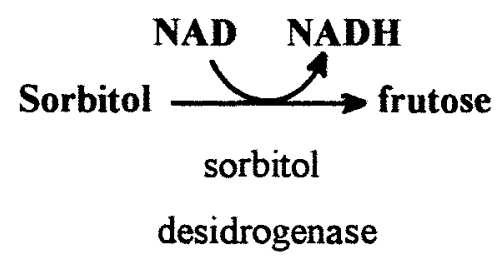

3.8.11- glicose 6-fosfato desidrogenase (D-glicose 6-fosfato: NADP 1-oxidoredutase, EC 1.1.1.49)

A mistura de reação continha num volume final de $1 \mathrm{~mL}$ : tampão HEPES $50 \mathrm{mM}$ pH 7.2, acetato de magnésio 5Mm, NADP $1 \mathrm{mM}$ e glicose 6-fosfato $1 \mathrm{mM}$. A reação, representada pela equação abaixo, foi iniciada pela adição da glicose 6-fosfato (Doehlert et al., 1988).

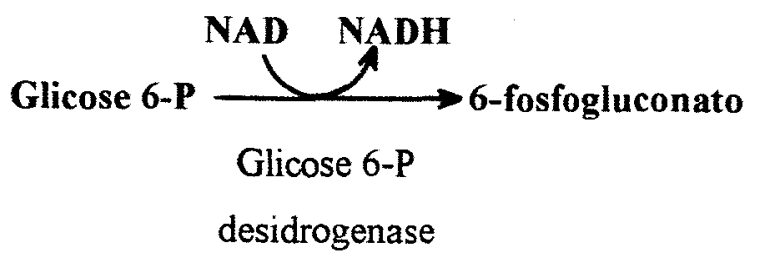

\subsubsection{2- glicerolquinase}

A mistura de reação continha num volume final de $1 \mathrm{~mL}$ : tampão NAD (HEPES/NaOH $100 \mathrm{mM}$ pH8.0; acetato $\mathrm{Mg} 3 \mathrm{mM}$; DTT $5 \mathrm{mM}$; glicose 1,6 bisfosfato $0.02 \mathrm{mM}$; NAD $0.5 \mathrm{mM}$ ), glicerol $3 \mathrm{mM}$, ATP $1 \mathrm{mM}$ e 2 unidades de glicerol 3-fosfato 
desidrogenase. A reação, representada pela equação abaixo, foi iniciada pela adição do ATP (Grunnet \& Lundquist, 1967 - modificado).

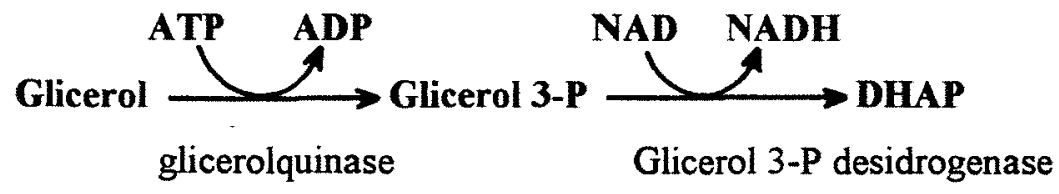

\subsubsection{3- glicerol 3-fosfato desidrogenase}

A mistura de reação continha num volume final de $1 \mathrm{~mL}$ : tampão NAD (HEPES/NaOH 100mM pH8.0; acetato $\mathrm{Mg} 3 \mathrm{mM}$; DTT $5 \mathrm{mM}$; glicose 1,6 bisfosfato $0.02 \mathrm{mM}$; NAD 0.5mM), glicerol 3mM, ATP $1 \mathrm{mM}$ e 2 unidades de glicerolquinase. A reação, representada pela equação abaixo, foi iniciada pela adição do ATP (Grunnet \& Lundquist, 1967 - modificado).

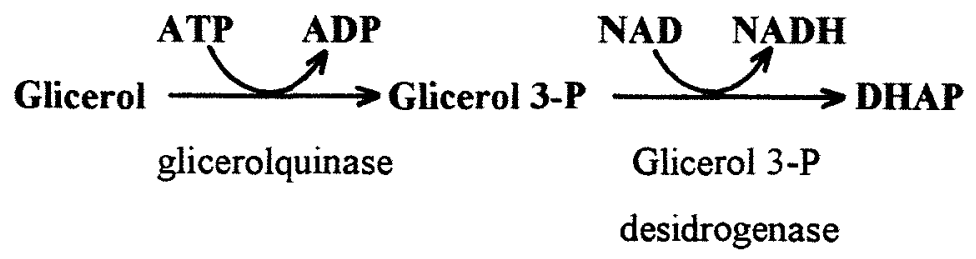

\subsubsection{4- aldose redutase}

A mistura de reação continha num volume final de $1 \mathrm{~mL}$ : tampão NAD (HEPES/NaOH 100mM pH8.0; acetato $\mathrm{Mg} 3 \mathrm{mM}$; DTT $5 \mathrm{mM}$; glicose 1,6 bisfosfato $0.02 \mathrm{mM}$; NAD $0.5 \mathrm{mM}$ ) e glicerol $3 \mathrm{mM}$. A reação, representada pela equação abaixo, foi iniciada pela adição do glicerol (Metzler, 1977).

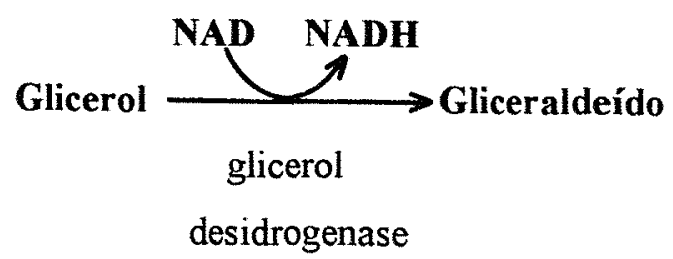




\section{9- Cálculo e expressão da atividade das enzimas:}

As densidades óticas à $340 \mathrm{~nm}$ obtidas foram utilizadas segundo a eq. (3) para o cálculo da atividade das enzimas que foram expressas em $\mathrm{nmol} / \mathrm{min} \times \mathrm{mg}$ proteína.

$\mathrm{DO}_{340} \times 1000000 / 6,22 \times$ (extrato $\mu \mathrm{L} \times$ conteúdo de proteína $\mu \mathrm{g} / \mu \mathrm{L}$ )

\subsection{0- Análise da concentração protéica:}

O teor de proteína na suspensão celular foi determinado com base no método descrito por Bradford (1976), onde $10 \mu \mathrm{L}$ de extrato das amostras foram adicionados a $1 \mathrm{~mL}$ do reagente de Bradford (50 mg Coomosie Briliant Blue G-250, dissolvido em 25 $\mathrm{ml}$ de etanol, adiciona-se $50 \mathrm{ml}$ de ácido fosfórico e completa-se o volume a $500 \mathrm{ml} \mathrm{com}$ água) para reagir por 10 minutos. Após a reação, determinou-se a concentração protéica das amostras espectrofotometricamente com base na densidade ótica a $590 \mathrm{~nm}$ tomandose como base uma reta padrão construída com BSA (soro albumina bovina) em concentrações de proteína variando de 0,5 a $5,0 \mu \mathrm{g}$.

\subsection{1- Análise Estatística}

Utilizando-se do sistema para análise estatística SAS, foi realizada a análise da variância segundo o modelo fatorial de $4 \times 10$, no delineamento em blocos casualizados, com 4 repetições, assim como a análise de variância da regressão polinomial. Foi utilizada a transformação logaritmo para os dados em miligramas para as variáveis massa fresca e massa seca e a transformação $\mathrm{x}^{0,2}$ para a variável proteína. 


\section{4- RESULTADOS E DISCUSSÃO}

\section{1- Ganho de biomassa}

\subsection{1- Massa fresca}

A fonte de carbono afetou intensa e distintamente o ganho de massa fresca pelas culturas de célula em suspensão das três espécies de plantas como observado nas Figuras 3, 4 e 5 e Tabelas A1, A2 e A3 (Apêndice) para Bauhinia forficata, Curcuma zedoaria e Phaseolus vulgaris, respectivamente.

A sacarose, que é a fonte de carbono rotineiramente utilizada nos trabalhos in vitro com células de plantas, foi a que proporcionou maior ganho de massa fresca entre os carboidratos testados. O maior crescimento foi atingido por $P$. vulgaris com $\Delta \mathrm{PF}_{25}=5,793 \mathrm{~g}$, seguido de $C$. zedoaria com $\Delta \mathrm{PF}_{35}=4,926 \mathrm{~g}$ e $B$. forficata com $\Delta \mathrm{PF}_{40}=1,428 \mathrm{~g}$. Tanto as culturas de $C$. zedoaria como de $P$. vulgaris apresentaram uma curva de crescimento sigmoidal característica (Figuras 4 e 5) representada por uma fase inicial "lag", onde o crescimento é lento devido a adaptação das células ao novo meio de cultura, seguida por uma fase "log", caracterizada pelo crescimento intenso da cultura até atingir uma fase estacionária no final do período, podendo esta ser ou não seguida por uma fase de decréscimo na massa fresca da cultura, que representa o ponto onde não há mais sacarose suficiente no meio e a manutenção das células ocorre pelo consumo de reservas internas próprias ou devido ao acúmulo de produtos tóxicos no meio de cultura excretados pelas células. 


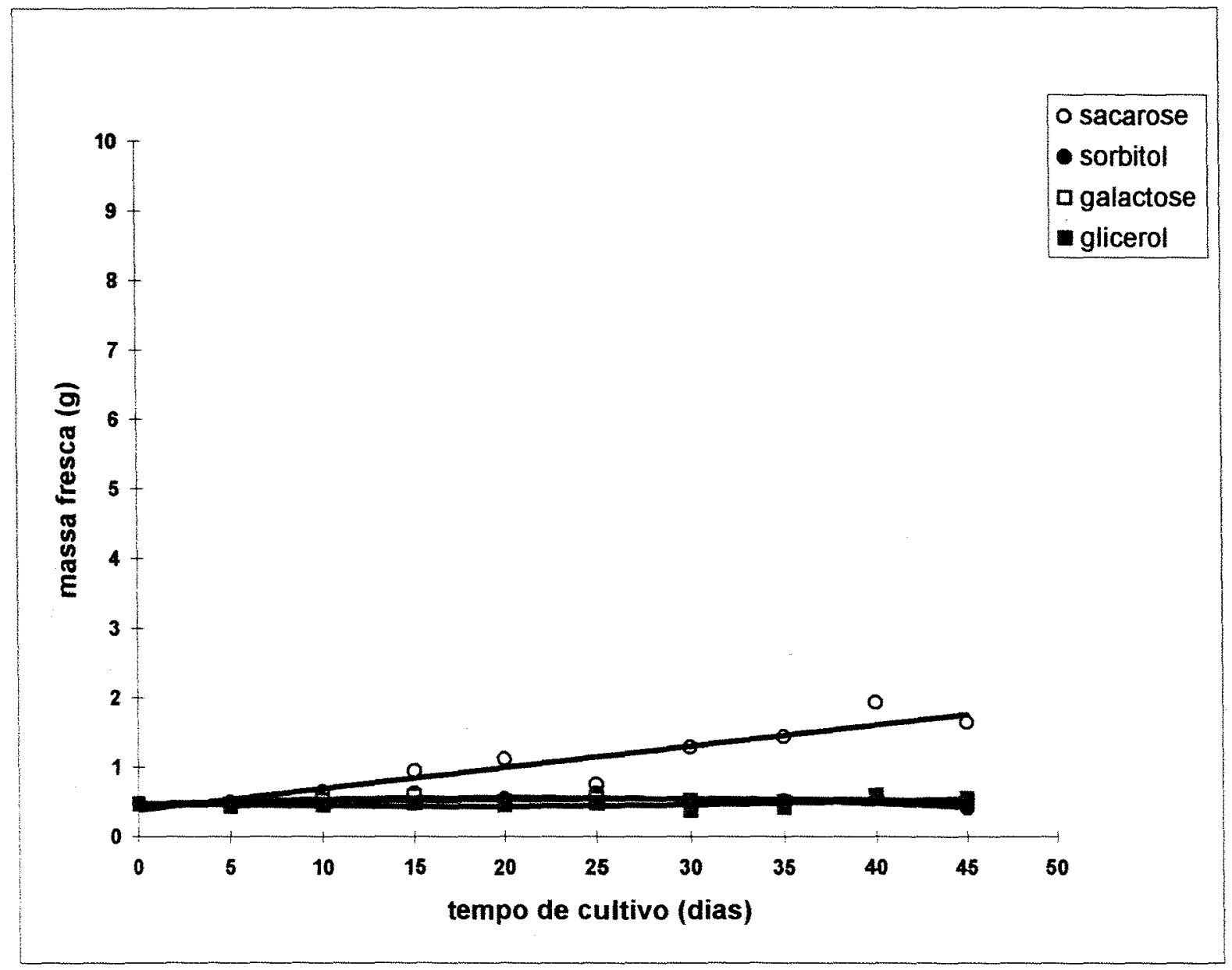

Figura 3: Efeito de diferentes fontes de carbono no crescimento celular (ganho de massa fresca) de culturas de células em suspensão de Bauhinia forficata Link $\left(\mathbf{R}^{2}\right.$ sacarose $=0,8617 ; \mathbf{R}^{2}$ sorbitol $=0,2778 ; R^{2}$ galactose $=0,3251 ; R^{2}$ glicerol $=$ $0,3948)$. 


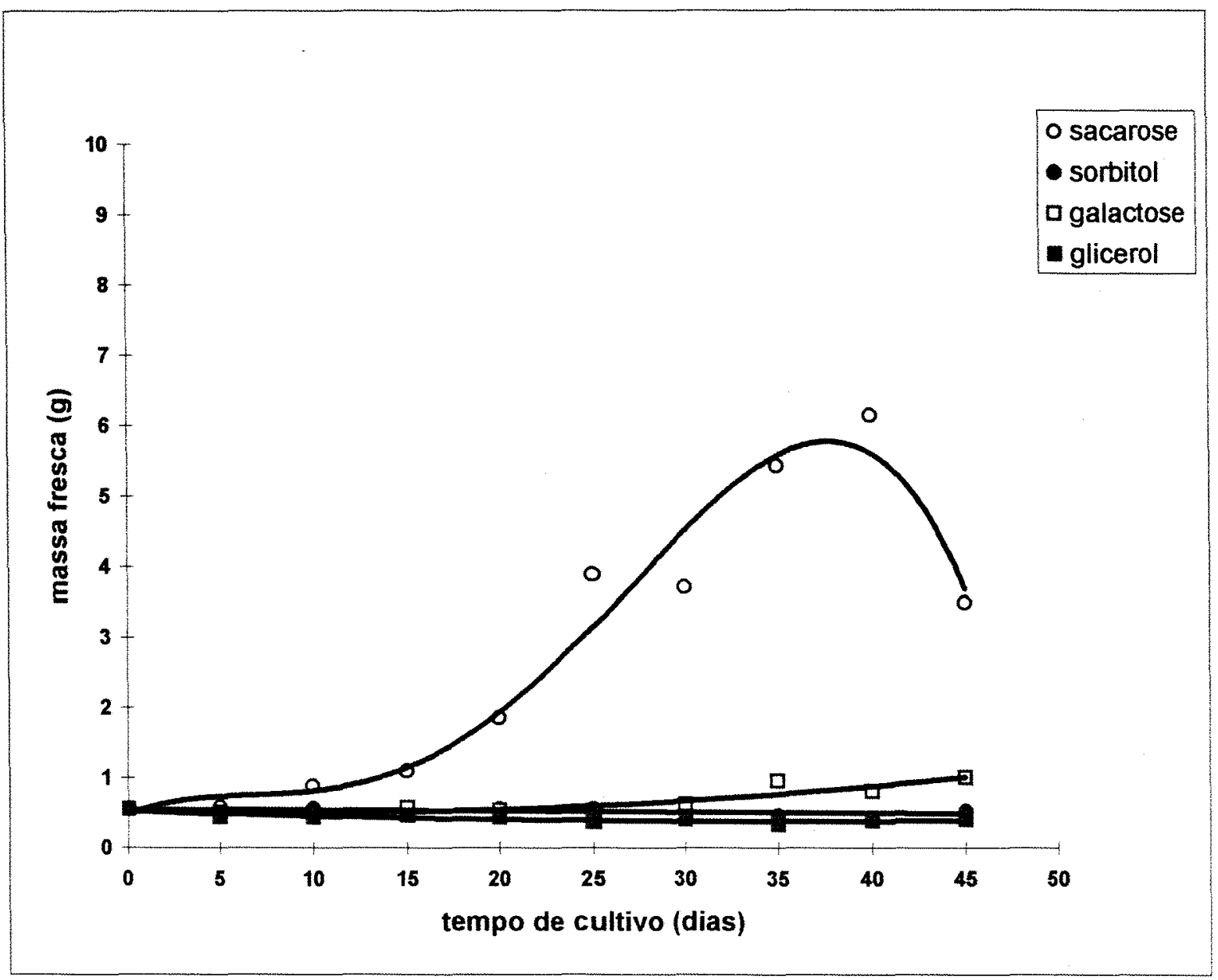

Figura 4: Efeito de diferentes fontes de carbono no crescimento celular (ganho de massa fresca) de culturas de células em suspensão de Curcuma zedoaria $\left(\mathrm{R}^{2}\right.$ sacarose $=0,9577 ; \mathbf{R}^{2}$ sorbitol $=0,2701 ; \mathbf{R}^{2}$ galactose $=0,8331 ; \mathbf{R}^{2}$ glicerol $\left.=0,7381\right)$. 


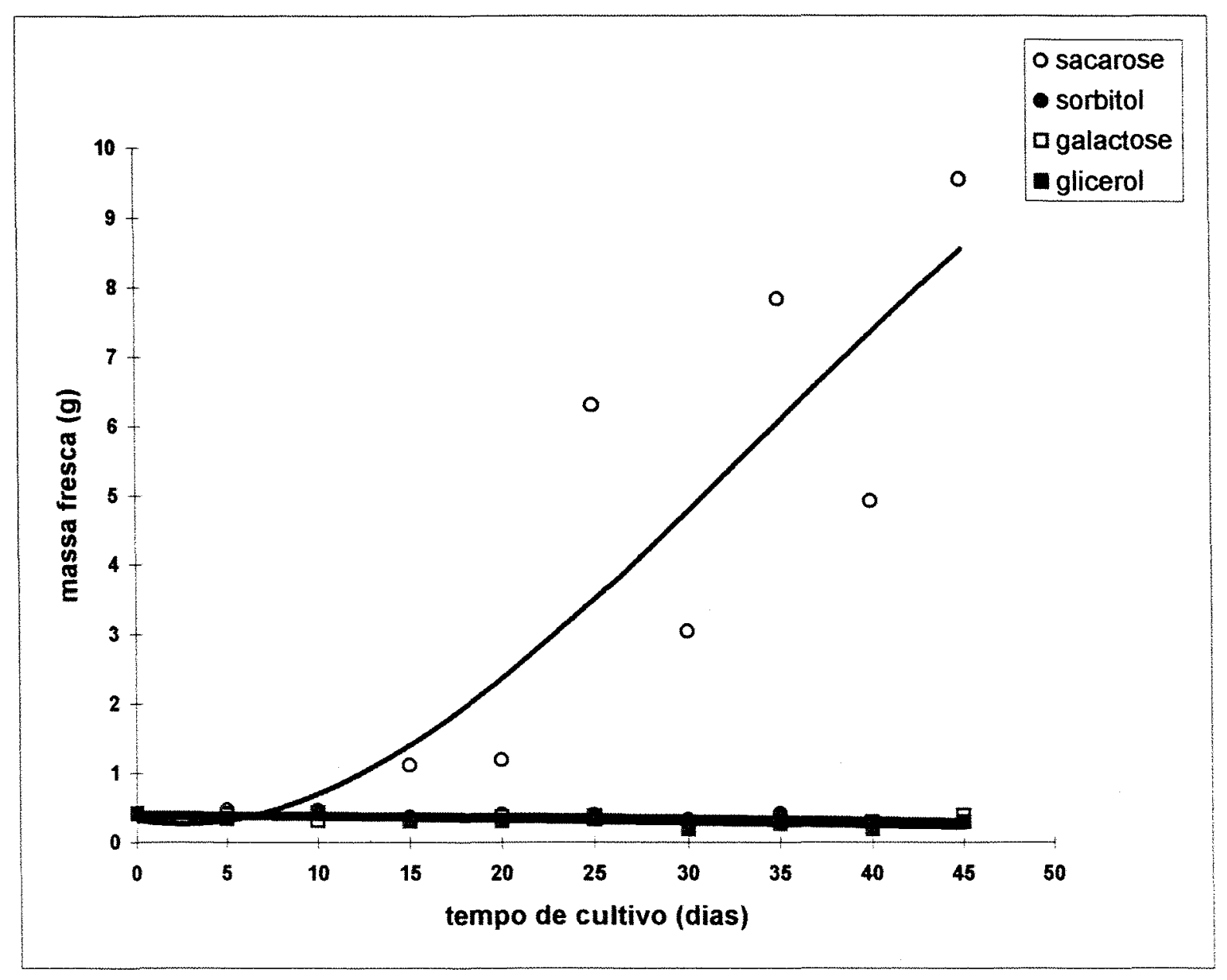

Figura 5: Efeito de diferentes fontes de carbono no crescimento celular (ganho de massa fresca) de culturas de células em suspensão de Phaseolus vulgaris $\left(\mathrm{R}^{2}\right.$ sacarose $=0,7822 ; \mathbf{R}^{2}$ sorbitol $=0,5010 ; \mathbf{R}^{2}$ galactose $=0.5088 ; \mathbf{R}^{2}$ glicerol $\left.=0,5255\right)$. 
As culturas de $B$. forficata não apresentaram comportamento semelhante ao observado para $C$. zedoaria e $P$. vulgaris. Ao invés de uma curva sigmoidal típica, o crescimento das culturas de células em suspensão de $B$. forficata pode ser representado por uma reta. A razão para esta espécie fugir ao modelo padrão comum seguido pela maioria das espécies pode ser atribuído ao baixo crescimento observado nestas culturas (Figura 3) que é bem inferior àquele apresentado pelas culturas de C. zedoaria (Figura 4) e $P$. vulgaris (Figura 5). No caso das culturas de células em suspensão de $B$. forficata 0 esgotamento da sacarose, assim como a síntese significativa de substâncias tóxicas por estas células provavelmente não estariam ocorrendo, o que as manteriam em crescimento contínuo por período de tempo mais longo.

$\mathrm{O}$ sorbitol que está presente como produto da fotossíntese e chega a representar até $90 \%$ do carbono exportado das folhas em alguns membros das famílias Rosaceae, Prunoideae e Spiroideae, parece ser uma fonte de carbono promissora para a utilização in vitro por células de plantas (Welander et al., 1989; Borkowska \& Szczerba, 1991; Marino et al., 1993; Karhu, 1997). Porém, em B. forficata, C. zedoaria e P. vulgaris, espécies testadas neste trabalho, o sorbitol não estimulou o crescimento das culturas de células em suspensão, levando mesmo a uma diminuição da massa inicial após 45 dias. A variação da massa fresca avaliada pelo parâmetro $\Delta \mathrm{PFt}$ foi de $0,007 \mathrm{~g}$ para $B$. forficata aos 35 dias (Tabela A1- Apêndice), 0,026g para C. zedoaria aos 45 dias (Tabela A2Apêndice) e $-0,093 \mathrm{~g}$ para $P$. vulgaris aos 35 dias (Tabela A3- Apêndice).

Os resultados negativos obtidos com o sorbitol mostram que, talvez por não ser um açúcar encontrado nos exudatos de seiva de floema das espécies estudadas (Zimmermann \& Ziegler, 1975), o mesmo não possa ser utilizado por células em suspensão destas espécies como fonte de carbono e energia. Este fato pode estar relacionado com a dificuldade de absorção deste carboidrato ou com a ausência das enzimas do metabolismo dos açúcares alcoólicos nestas espécies (Jain et al., 1997) como mostram os resultados obtidos neste trabalho com a enzima sorbitol desidrogenase (Tabelas 2, 3 e 4). Resultados similares foram obtidos para os gêneros Syringa e Alnus (Welander et al., 1989), Quercus (Romano et al., 1995) e Peplis (Samyn, 1995). 
O glicerol, que já havia se mostrado incapaz de promover o crescimento in vitro de calos de Lactuca (Roberts \& Baba, 1982) e Citrus (Kahn, 1995), também não propiciou aumento significativo de massa fresca nas culturas de células das espécies estudadas. Ao contrário, em C. zedoaria (Tabela A2- Apêndice) e P. vulgaris (Tabela A3- Apêndice), houve uma diminuição da massa fresca das culturas após 45 dias e em $B$. forficata, esta não se alterou. Os valores de $\triangle \mathrm{PFt}$ foram de $0,076 \mathrm{~g}$ para $B$. forficata aos 40 dias, $-0,120 \mathrm{~g}$ para $C$. zedoaria aos 40 dias e $-0,211 \mathrm{~g}$ para $P$. vulgaris aos 45 dias.

Segundo Jones \& Veliky (1980), o glicerol se torna tóxico para certas culturas quando utilizado em concentração acima de 3\% no meio de cultura. Este fato pode explicar os resultados obtidos já que nas condições estudadas o glicerol foi utilizado na concentração de $12 \%$, quatro vezes superior a concentração limitante citada pelos autores. Além disto, a ausência de atividade das enzimas responsáveis pela metabolização do glicerol (glicerolquinase, glicerol 3-fosfato desidrogenase e aldose redutase) (Tabelas 2, 3 e 4) a compostos que entrariam diretamente nas vias glicolíticas ou gliconeogênicas poderia ser outro fator que estaria limitando o desenvolvimento das células em meio suplementado com glicerol como fonte de carbono.

A galactose vem sendo utilizada para a suplementação dos meios de cultura porque é absorvida por células de plantas, podendo ser incorporada na parede celular ou utilizada na síntese de sacarose (Maretzki \& Thom, 1978).

As culturas de células em suspensão de $C$. zedoaria quando cultivadas em galactose apresentaram acúmulo de massa fresca final que correspondeu a três vezes menos do que o observado em presença de sacarose. O crescimento aos 35 dias foi também 10 vezes menor, o que pode ser observado pelos valores $\Delta \mathrm{PF}_{35}=4,926 \mathrm{~g}$ para sacarose e $\Delta \mathrm{PF}_{35}=0,452 \mathrm{~g}$ para galactose. Menor crescimento celular em galactose quando comparado com sacarose foi também observado em Beta vulgaris (Monroy et al., 1994) e Citrus deliciosa (Cabasson et al., 1995).

As culturas de $B$. forficata e $P$. vulgaris não apresentaram crescimento mensurável quando cultivadas em meio com galactose $\left(\Delta \mathrm{PF}_{40}=0,088 \mathrm{~g}\right.$ e $\Delta \mathrm{PF}_{35}=-0,241 \mathrm{~g}$, respectivamente), embora outros trabalhos mostrem seu efeito benéfico sob 0 crescimento de Picrasma quassioides (Scragg \& Allan, 1986) e de Peplis diandra 
(Samyn, 1995) e sob a diferenciação celular de Rosa rugosa (Kunitake et al., 1993), de Triticum aestivum (Navarro, 1994) e de Citrus (Cabasson et al., 1995). A razão pela qual células em suspensão cultivadas em galactose não crescem pode ser atribuida ao efeito tóxico da galactose sob culturas in vitro, que foi primeiro registrado por Maretzki \& Thom (1978) e que se caracteriza por necrose e posterior morte celular. Recentemente, tem-se confirmado o efeito negativo da galactose sob algumas espécies cultivadas in vitro como Dioscorea deltoidea (Rokem et al., 1985) e Zea mays (Swedlund \& Locy, 1993).

\subsection{2- Massa seca}

Os resultados obtidos para o ganho de massa seca podem ser observados nas Figuras 6, 7 e 8 e nas Tabelas A4, A5 e A6 (Apêndice) para B. forficata, C. zedoaria e $P$. vulgaris, respectivamente. Do mesmo modo que ocorreu com a massa fresca, a variação de massa seca entre os tratamentos foi bastante significativa.

A exemplo do que ocorreu com o ganho de massa fresca, somente a sacarose, que é amplamente utilizada como fonte de carbono na suplementação do meio de cultura da maioria das espécies de plantas, inclusive dos gêneros Curcuma (Dekkers et al,, 1991; Barthakur \& Bordoloi, 1992), Bauhinia (Kumar, 1992; Upreti \& Dhar, 1996) e Phaseolus (Dillen et al., 1996; Barros et al., 1997), promoveu acúmulo significativo de massa seca nas três espécies estudadas. O maior acúmulo foi observado em $P$. vulgaris onde $\Delta \mathrm{PS}_{25}=0,650 \mathrm{~g}$, seguido de $C$. zedoaria com $\Delta \mathrm{PS}_{25}=0,193 \mathrm{~g}$ e $B$. forficata com $\Delta \mathrm{PS}_{40}=0,137 \mathrm{~g}$. $\mathrm{O}$ mesmo comportamento observado para as curvas de crescimento em termos de massa fresca para as três culturas foi também observado para massa seca. $C$. zedoaria (Figura 7) e P. vulgaris (Figura 8) apresentaram curvas de crescimento sigmoidais típicas, enquanto que B. forficata (Figura 6) apresentou uma reta. Por ser $B$. forficata a única lenhosa entre as três espécies estudadas, é possível que este comportamento apresentado por esta espécie, que foge ao padrão comum apresentado pela maioria das espécies de plantas estudadas, seja uma característica comum deste tipo de leguminosas. 


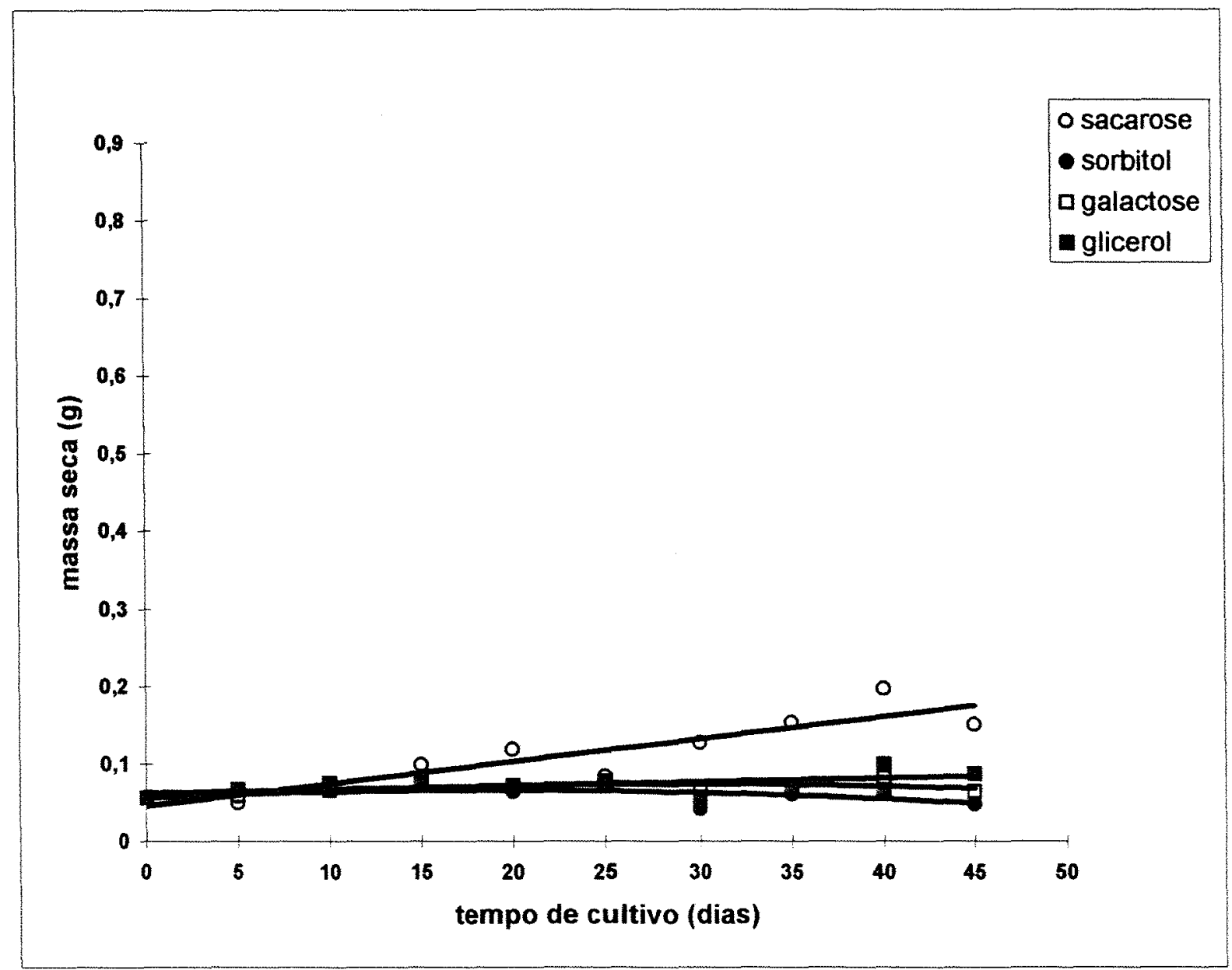

Figura 6: Efeito de diferentes fontes de carbono no crescimento celular (ganho de massa seca) de culturas de células em suspensão de Bauhinia forficata Link $\left(R^{2}\right.$ sacarose $=0,8185 ; R^{2}$ sorbitol $=0,2708 ; R^{2}$ galactose $=0,5875 ; R^{2}$ glicerol $=$ $0,3355)$. 


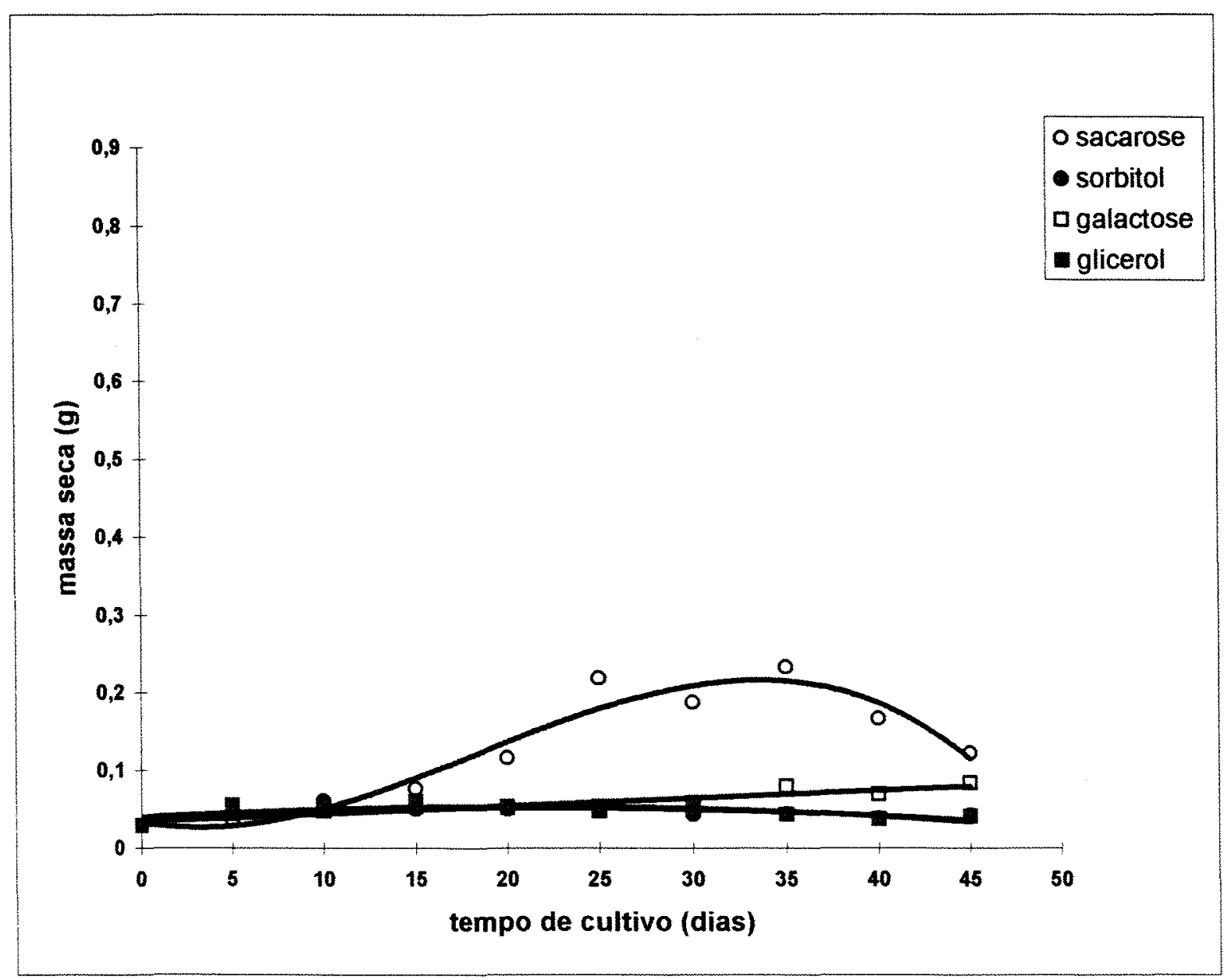

Figura 7: Efeito de diferentes fontes de carbono no crescimento celular (ganho de massa seca) de culturas de células em suspensão de Curcuma zedoaria Roscoe $\left(\mathrm{R}^{2}\right.$ sacarose $=0,9304 ; \mathrm{R}^{2}$ sorbitol $=0,3998 ; \mathrm{R}^{2}$ galactose $=0,8777 ; \mathrm{R}^{2}$ glicerol $=$ $0,5342)$. 


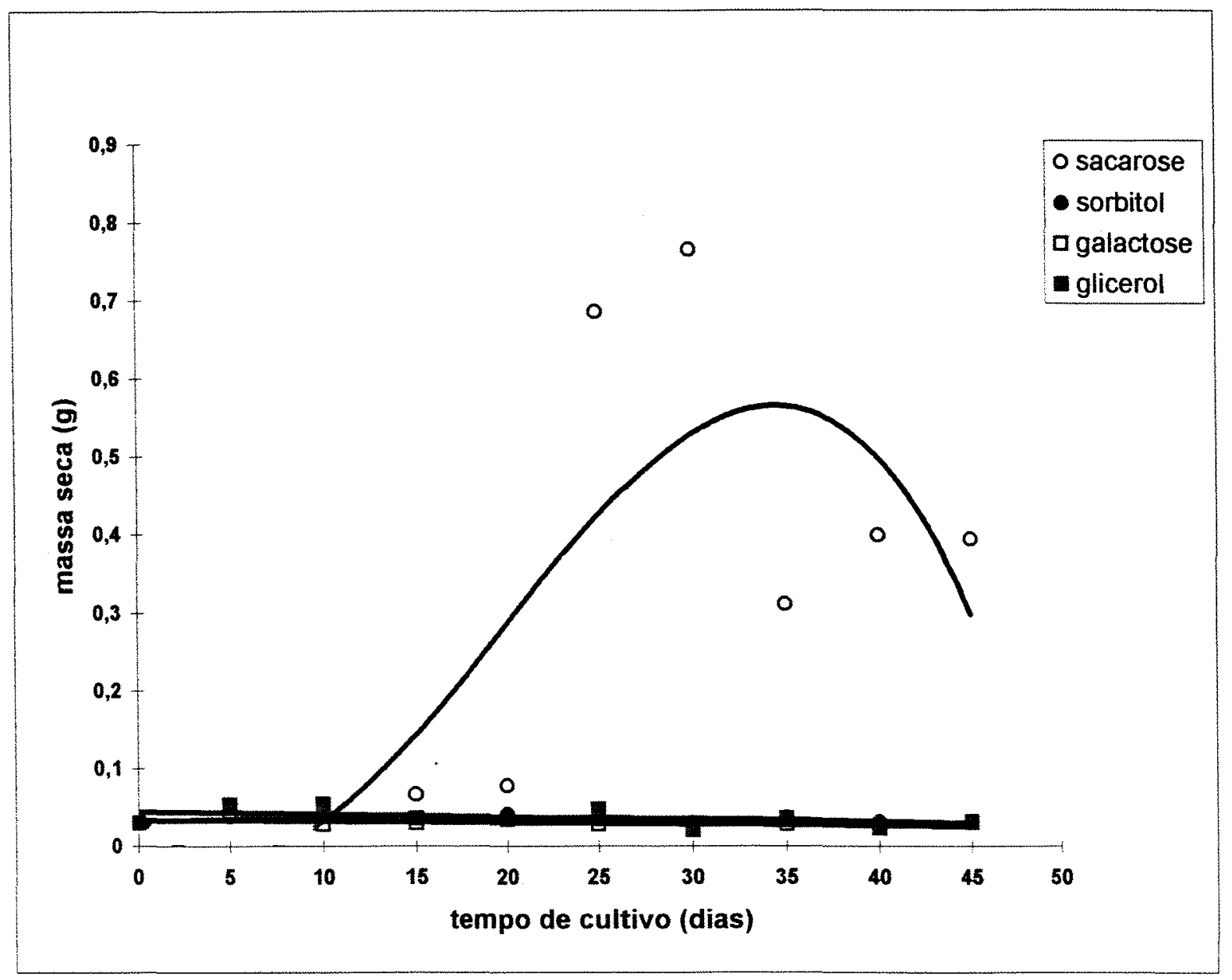

Figura 8: Efeito de diferentes fontes de carbono no crescimento celular (ganho de massa seca) de culturas de células em suspensão de Phaseolus vulgaris $\left(\mathrm{R}^{2}\right.$ sacarose $=0,6269 ; \mathbf{R}^{2}$ sorbitol $=0,3496 ; \mathbf{R}^{2}$ galactose $=0,2274 ; \mathbf{R}^{2}$ glicerol $\left.=0,2511\right)$. 
De uma maneira geral, as fontes de carbono alternativas não alteraram significativamente o perfil de acúmulo de massa seca das culturas de célula em suspensão nas três espécies estudadas durante o período de cultivo. Porém, glicerol em B. forficata (Figura 6) e galactose em C. zedoaria (Figura 7) e B. forficata (Figura 6), proporcionaram certo crescimento, mas sempre inferior ao obtido com a sacarose.

$\mathrm{O}$ valor de $\triangle \mathrm{PS}$ aos 35 dias para as culturas de $B$. forficata e de $P$. vulgaris crescendo em sorbitol como fonte de carbono foi zero. A inalteração da massa seca em culturas de células in vitro mantidas em sorbitol pode ocorrer, segundo Jain et al. (1997), devido ao fato de que o sorbitol age principalmente como regulador osmótico e, ao contrário do que ocorre com a sacarose, este não estimula o crescimento in vitro além do que este pode não ser metabolizado pela maioria das plantas. Nos experimentos realizados ambos os fatores podem ter influenciado os resultados negativos obtidos com a utilização do sorbitol já que este foi adicionado ao meio de cultura na concentração de $6 \%$ enquanto que a sacarose foi utilizada na concentração de $3 \%$. Além disto, os resultados da atividade da sorbitol desidrogenase, que é a enzima responsável pela metabolização do sorbitol a frutose, mostram uma atividade muito baixa ou não detectável desta enzima nas culturas das três espécies estudadas. Nas culturas de células em suspensão de $C$. zedoaria foi observado um pequeno crescimento $\left(\Delta \mathrm{PS}_{45}=0,016 \mathrm{~g}\right)$, onde $o$ acúmulo de massa seca máximo foi 5 vezes menor nesta fonte de carbono do que em sacarose.

O glicerol que proporcionou crescimento final de cultura de células em suspensão de Acer pseudoplatamus comparável com o crescimento das mesmas observado em sacarose (Grout et al., 1976), em culturas de células de B. forficata promoveu crescimento expresso em aumento de massa seca 3,5 vezes menor do que aquele obtido para sacarose $\left(\triangle \mathrm{PS}_{40}=0,039 \mathrm{~g}\right)$ ou um acúmulo de massa seca máximo 2 vezes menor. As culturas de $C$. zedoaria apresentaram acúmulo de massa seca máximo 5 vezes menor do que a observada para sacarose, com um aumento de massa seca expresso por $\Delta \mathrm{PS}_{45}=0,014 \mathrm{~g}$. Por outro lado, esta fonte de carbono não alterou o perfil de acúmulo de massa seca das culturas de células em suspensão de $P$. vulgaris $\left(\triangle \mathrm{PS}_{35}=0,00 \mathrm{~g}\right)$. 
A galactose promoveu aumento de massa seca em B. forficata $\left(\Delta \mathrm{PS}_{40}=0,021 \mathrm{~g}\right) \mathrm{e}$ C. zedoaria $\left(\Delta \mathrm{PS}_{35}=0,053 \mathrm{~g}\right)$ de cerca de 3,6 e 6,5 vezes menor do que o obtido com sacarose. O maior crescimento de células in vitro cultivadas em sacarose quando comparado com o crescimento das mesmas em meio suplementado com galactose se deve a maior eficiência das células no aproveitamento da sacarose como fonte de carbono (Monroy et al., 1994).

Nas culturas destas espécies não se observou os sintomas de toxidez que geralmente se desenvolvem em culturas quando a galactose é utilizada em concentrações elevadas no meio de cultura (Maretzki \& Thom, 1978; Lemos \& Blake, 1996). Maretzki \& Thom (1978), destacam que quando não adaptadas à galactose, células em suspensão de Saccharum sp se tornam necróticas e param de crescer. Por sua vez, após adaptação, estas células apresentavam um crescimento próximo àquele obtido em meio suplementado com sacarose. Isto nos leva a crer que $C$. zedoaria apresenta uma capacidade de adaptação a esta fonte de carbono superior à apresentada por $B$. forficata. Culturas de células em suspensão de $P$. vulgaris não se adaptaram ao meio suplementado com galactose $\left(\triangle \mathrm{PS}_{40}=0,021 \mathrm{~g}\right)$ durante os 45 dias de cultivo $\mathrm{e}$ apresentaram início de oxidação caracterizado pelo escurecimento das células, indicando início do desenvolvimento do processo de toxidez descrito anteriormente.

Em todos os casos fica claro a superioridade da sacarose em relação às outras fontes de carbono. Isto não descarta a possibilidade da utilização destas fontes alternativas em outras espécies ou mesmo nas espécies estudadas como é o caso da galactose em C. zedoaria e B. forficata e do glicerol em B. forficata. Pelas Figuras 6 e 7 podemos observar uma tendência de aumento de massa seca nestas culturas para as fontes alternativas de carbono mencionadas anteriormente, no final do período de cultivo. O cultivo destas células por período de tempo mais longo que 45 dias poderia confirmar tais suposições. Além disto não fica descartada a hipótese de consorciação da sacarose com estas fontes alternativas de carbono visando a obtenção de resultados específicos como a diferenciação celular ou seleção de células resistentes a fatores ambientais como o estresse térmico e hídrico. Também parece necessário que testes 
utilizando outras concentrações das fontes de carbono aqui testadas sejam executados visando a otimização do crescimento em cada uma delas.

\section{2- Acúmulo de proteína}

Segundo Raghavan (1983), para se detectar mudanças na composição de macromoléculas durante o ciclo de crescimento de um tecido, é comum lançar mão de estratégias que obtenham uma medida quantitativa de níveis de síntese de macromoléculas e o aumento ou diminuição delas devido a síntese ou degradação. As macromoléculas nas quais tem se empregado maiores esforços são as proteínas e os ácidos nucléicos. No presente trabalho, foi efetuado o acompanhamento de mudanças na concentração protéica das células em suspensão durante o período de cultivo (Figuras 9,10 e 11 e Tabelas A7, A8 e A9- Apêndice).

A sacarose que é a fonte de carbono que propiciou maior acúmulo de massa fresca e seca nas três culturas estudadas, também proporcionou o maior acúmulo protéico (Figuras 9, 10 e 11), principalmente para células de $C$. zedoaria e $P$. vulgaris, onde a concentração de proteína das células cultivadas em sacarose foi bem maior do que a observada nas mesmas crescendo em meio de cultura suplementado com sorbtiol, galactose ou glicerol.

O aumento observado na concentração protéica das culturas de células em suspensão crescendo em fontes de carbono que não causaram aumento de matéria fresca e seca, provavelmente ocorreu as custas da mobilização de reservas internas de carbono presentes nas células como açúcares redutores, sacarose e amido (Frick, 1994). Este fato explica os aumentos na concentração protéica provocados pelo sorbitol em $B$. forficata $\mathrm{e}$ P. vulgaris onde nenhum ganho de biomassa foi observado. 


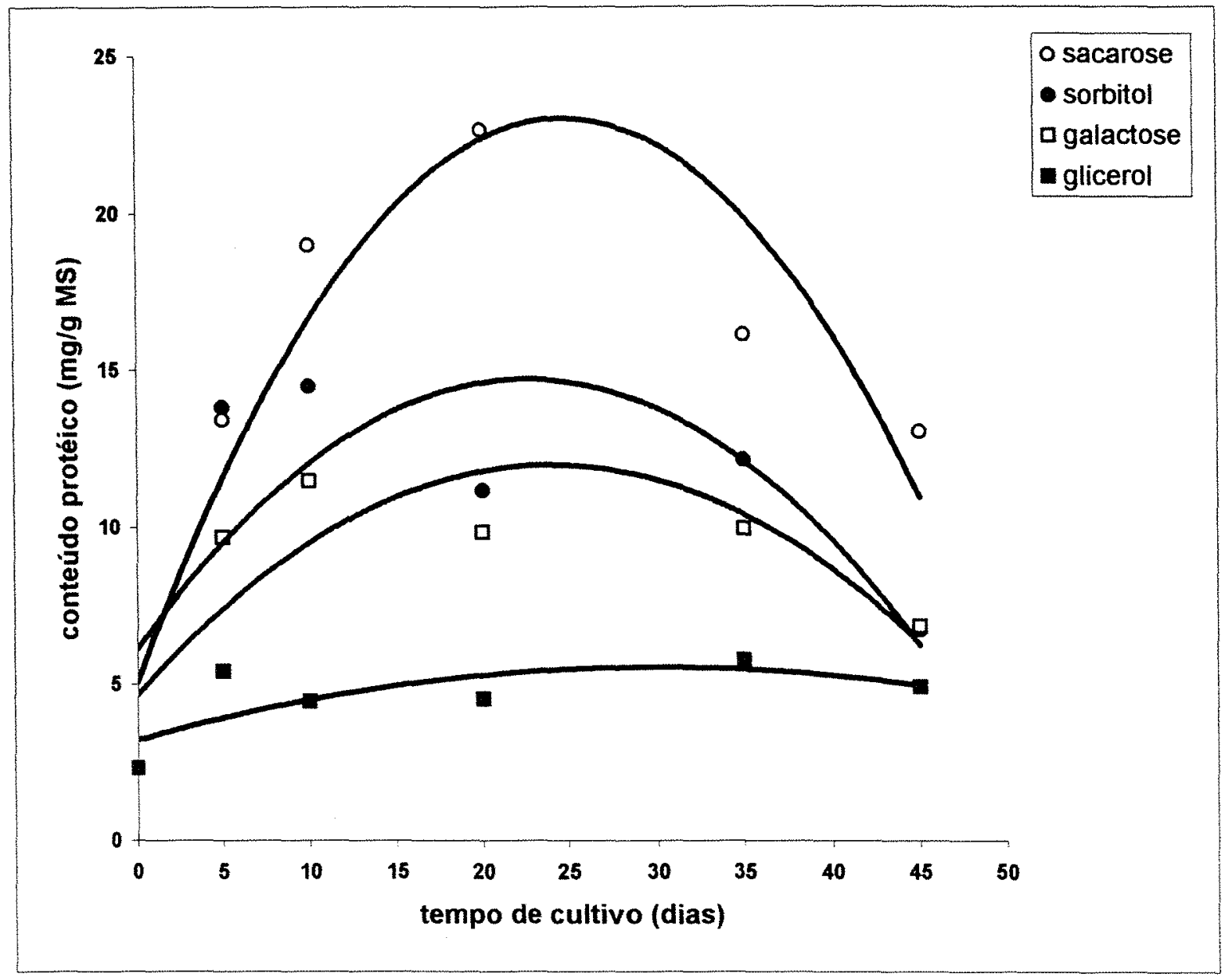

Figura 9: Efeito de diferentes fontes de carbono na evolução da concentração de proteína de culturas de células em suspensão de Bauhinia forficata Link $\left(\mathrm{R}^{2}\right.$ sacarose $=$ 0,$8534 ; R^{2}$ sorbitol $=0,5377 ; R^{2}$ galactose $=0,6571 ; R^{2}$ glicerol $\left.=0,5019\right)$. 


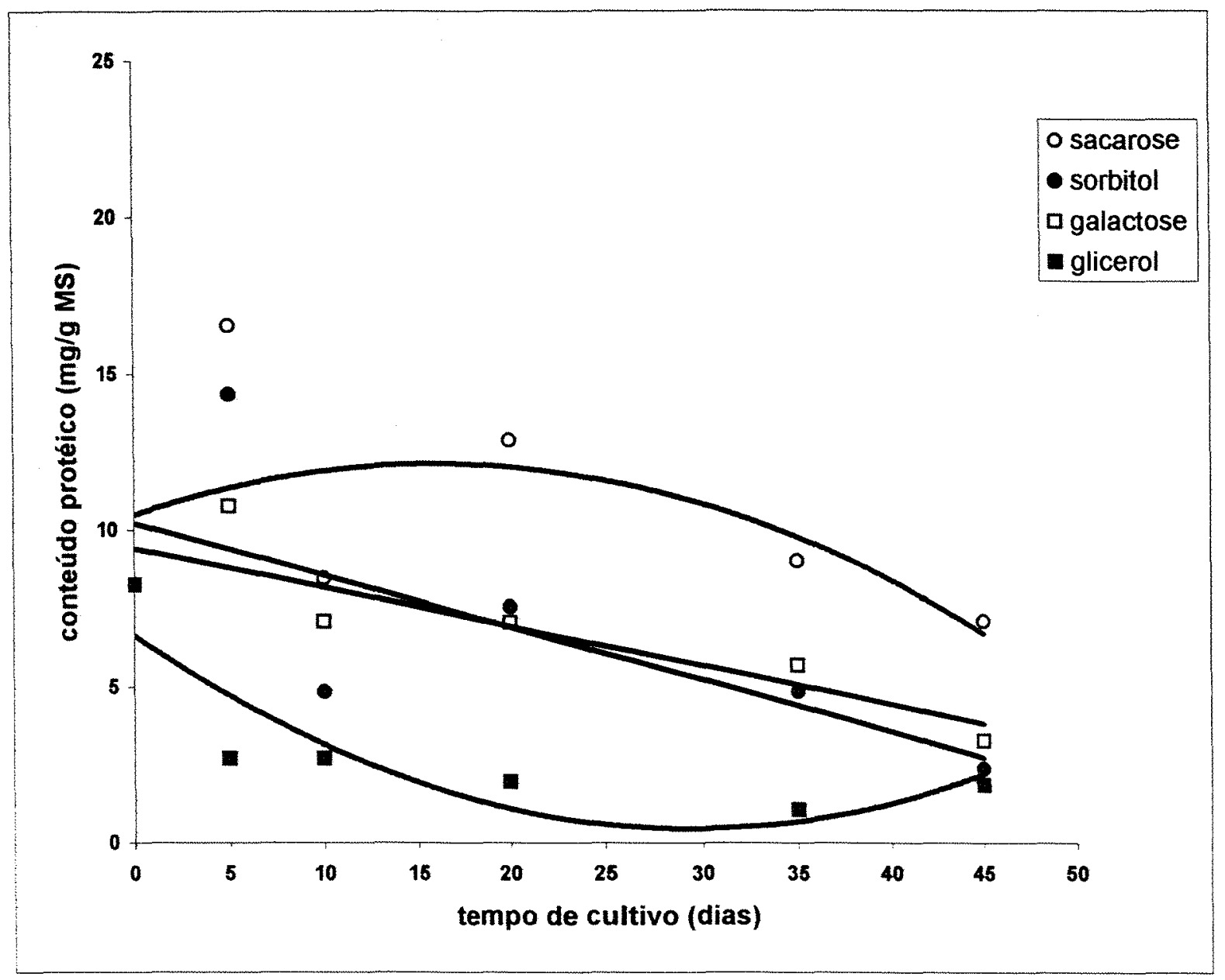

Figura 10: Efeito de diferentes fontes de carbono na evolução da concentração de proteína de culturas de células em suspensão de Curcuma zedoaria Roscoe $\left(R^{2}\right.$ sacarose $=0,3058 ; R^{2}$ sorbitol $=0,5022 ; R^{2}$ galactose $=0,7733 ; R^{2}$ glicerol $=0,7687$ ). 


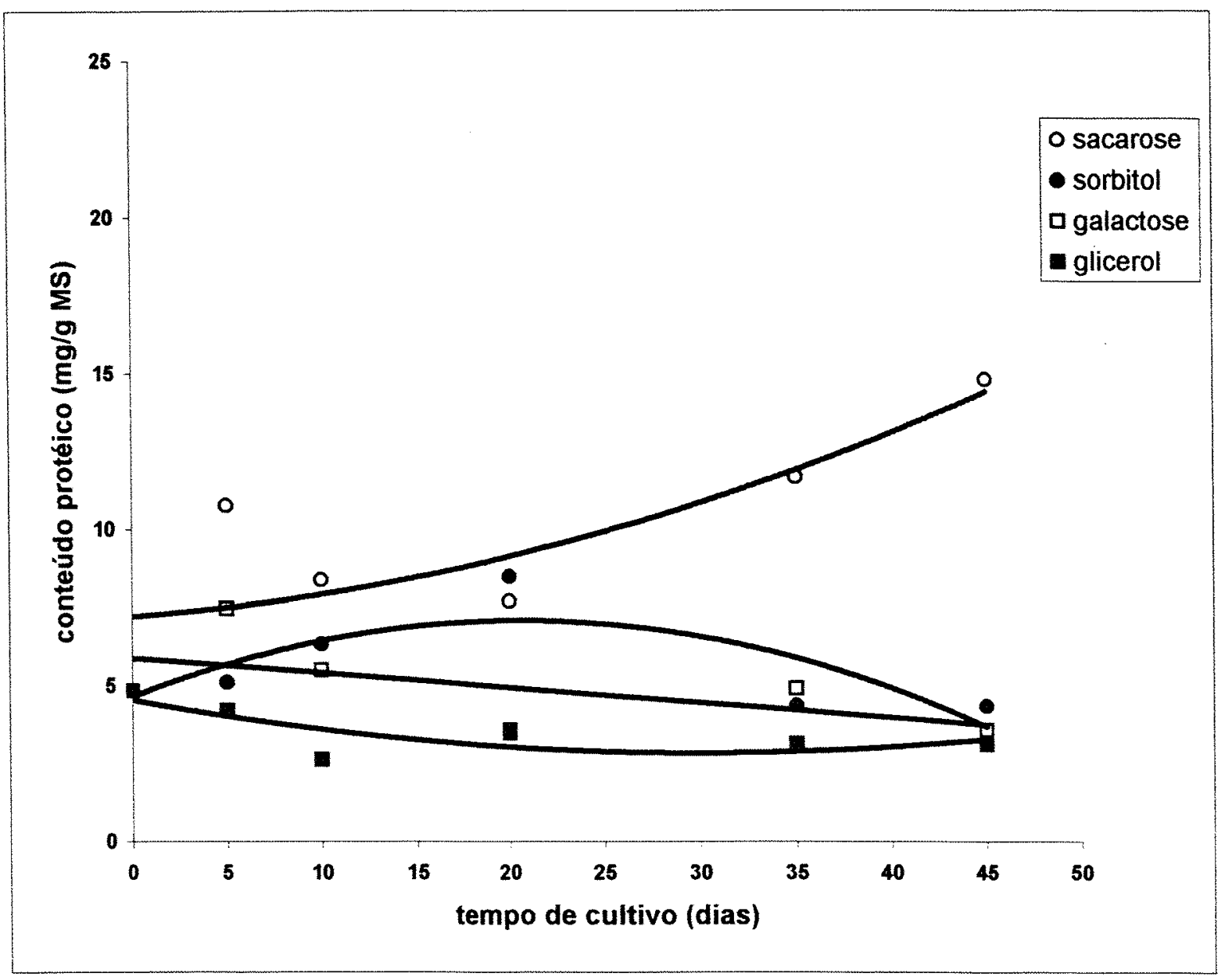

Figura 11: Efeito de diferentes fontes de carbono na evolução da concentração de proteína de culturas de células em suspensão de Phaseolus vulgaris $\left(R^{2}\right.$ sacarose $=0,6881 ; R^{2}$ sorbitol $=0,5979 ; R^{2}$ galactose $=0,3536 ; R^{2}$ glicerol $=0,6027)$. 
Resultados contraditórios foram obtidos quando células de C. zedoaria foram cultivadas em galactose. Neste caso houve aumento de massa seca e concentração protéica das células no início do cultivo, como o observado quando a sacarose foi utilizada como única fonte de carbono (Figuras 7 e 10). Em nenhum caso as fontes de carbono alternativas proporcionaram acúmulo de proteína superior aquele observado em sacarose, como ocorrido em Citrus (Vu et al., 1993; 1995) quando o glicerol foi empregado como única fonte de carbono.

\section{3- Atividade das enzimas do metabolismo de carboidratos}

Embora os carboidratos sejam de grande importância para o crescimento, desenvolvimento e diferenciação celular em cultura de tecidos, o metabolismo de carbono in vitro continua pouco compreendido (Romano et al., 1995).

Os extratos de células em suspensão de $B$. forficata, $C$. zedoaria e $P$. vulgaris cultivadas em meio de cultura líquido suplementado com sacarose, contém todas as enzimas necessárias para a conversão de sacarose a piruvato conforme mostrado na Figura 12. A enzima glicose 6-fosfato desidrogenase, que inicia a via pentose fosfato também está presente.

As atividades específicas destas enzimas nas células das três espécies estudadas cultivadas em meio de cultura contendo sacarose estão relacionadas nas Tabelas 2, 3 e 4. Comparado aos resultados encontrados por Boll (1991) em culturas de células em suspensão de Picea abies crescendo em meio de cultura suplementado com sacarose, as enzimas invertase ácida e neutra e UDP glicose pirofosforilase apresentaram atividades específicas bastante elevadas, superior a $300 \mathrm{nmol} / \mathrm{min} \times \mathrm{mg}$ proteína, enquanto que atividade específica baixa, inferior a $18 \mathrm{nmol} / \mathrm{min} \times \mathrm{mg}$ proteína, foi encontrada para a enzima frutose 1,6 bisfosfatase em $B$. forficata e $C$. zedoaria. Também as enzimas envolvidas no metabolismo do glicerol: glicerolquinase, glicerol 3-fosfato desidrogenase e aldose redutase apresentavam atividade muito baixa. 


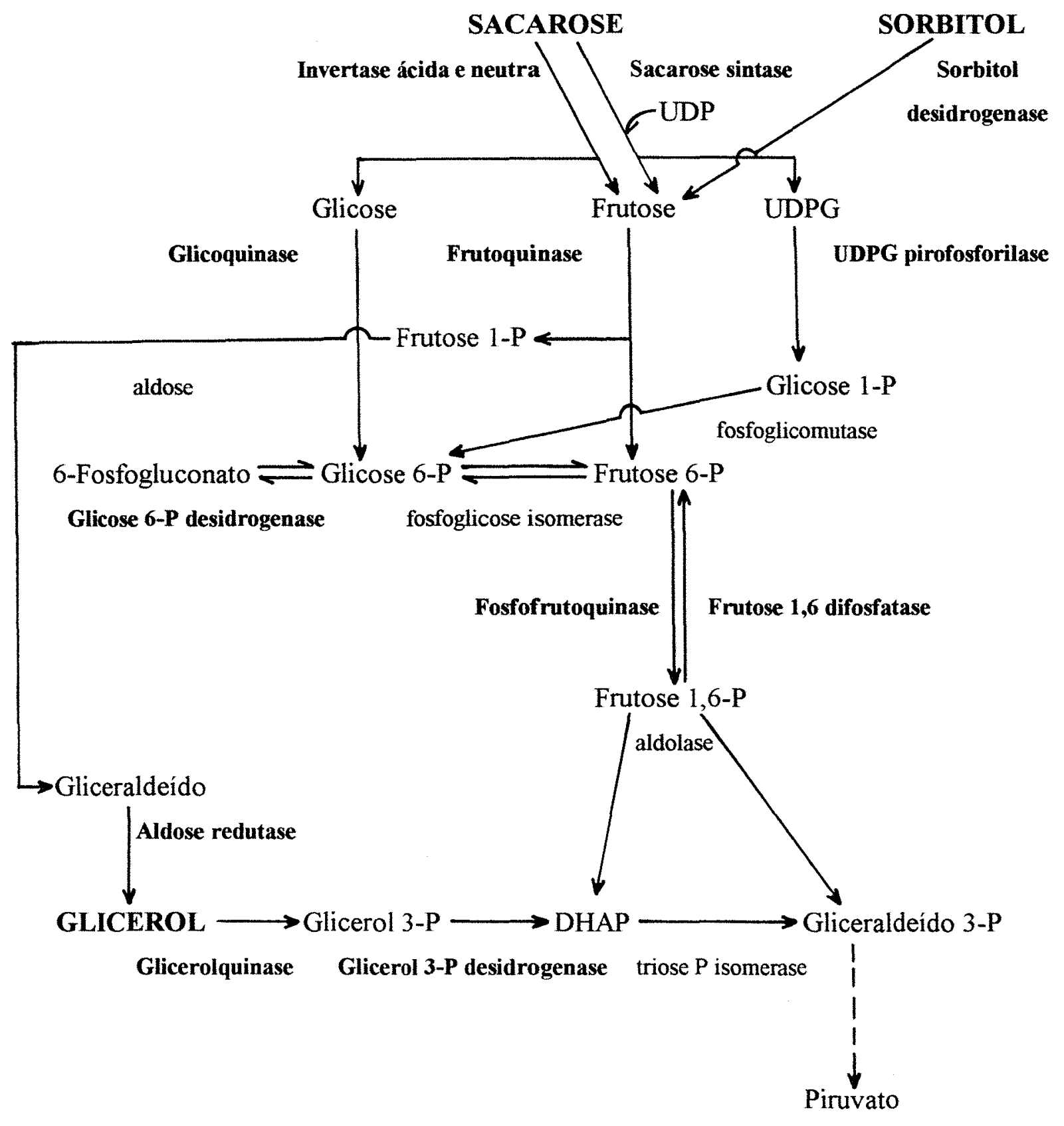

Figura 12: Enzimas analisadas da via de metabolização de carboidratos e as necessárias para a conversão de sacarose a piruvato (as enzimas estudadas estão em negrito). 
Tabela 2: Atividade específica ( $\mathrm{nmol} / \mathrm{min} \mathrm{x} \mathrm{mg}$ proteina) das enzimas do metabolismo de carboidratos e concentração protéica ( $\mu \mathrm{g} / \mathrm{mg}$ peso seco) em culturas de células em suspensão de Bauhinia forficata Link, crescendo em sacarose, nos dias $0,15,30$ e 40 .

\begin{tabular}{lllll}
\hline & \multicolumn{4}{c}{ TEMPO DE CRESCIMENTO (dias) } \\
\hline ENZIMAS & 0 & 15 & 30 & 40 \\
\hline Invertase ácida & 46.7 & 472.8 & 33869.2 & 2513.0 \\
Invertase neutra & $\mathrm{ND}$ & 637.3 & 32045.8 & 2541.0 \\
Fosfofrutoquinase - ATP & 117.9 & 133.6 & $\mathrm{ND}$ & 29.4 \\
Fosfofrutoquinase - PPi & $\mathrm{ND}$ & 494.3 & 2540.2 & 237.0 \\
Sacarose sintase & $\mathrm{ND}$ & $\mathrm{ND}$ & $\mathrm{ND}$ & $\mathrm{ND}$ \\
Glicose 6-fosfato desidrogenase & $\mathrm{ND}$ & 235.8 & $\mathrm{ND}$ & 132.2 \\
UDPG pirofosforilase & $\mathrm{ND}$ & 3309.7 & $\mathrm{ND}$ & 2320.4 \\
Frutoquinase & $\mathrm{ND}$ & 26.2 & $\mathrm{ND}$ & 37.9 \\
Glicoquinase & $\mathrm{ND}$ & 31.8 & $\mathrm{ND}$ & 4.7 \\
Sorbitol desidrogenase & $\mathrm{ND}$ & $\mathrm{ND}$ & $\mathrm{ND}$ & $\mathrm{ND}$ \\
Aldose redutase & $\mathrm{ND}$ & $\mathrm{ND}$ & $\mathrm{ND}$ & 9.0 \\
Glicerol 3-fosfato desidrogenase & $\mathrm{ND}$ & $\mathrm{ND}$ & $\mathrm{ND}$ & $\mathrm{ND}$ \\
Glicerol quinase & $\mathrm{ND}$ & $\mathrm{ND}$ & $\mathrm{ND}$ & $\mathrm{ND}$ \\
Frutose 1,6 difosfatase & $\mathrm{ND}$ & 35.9 & $\mathrm{ND}$ & $\mathrm{ND}$ \\
PROTEÍNA & 2.9 & 26.0 & 2.7 & 19.5 \\
\hline
\end{tabular}

$\mathrm{ND}=$ não detectável 
Tabela 3: Atividade específica ( $\mathrm{nmol} / \mathrm{min} \mathrm{x}$ mg proteína) das enzimas do metabolismo de carboidratos e concentração protéica ( $\mu \mathrm{g} / \mathrm{mg}$ peso seco) em culturas de células em suspensão de Curcuma zedoaria Roscoe, crescendo em sacarose, nos dias $0,15,30$ e 40 .

\begin{tabular}{lllll}
\hline & \multicolumn{4}{c}{ TEMPO DE CRESCIMENTO (dias) } \\
\hline ENZIMAS & 0 & 15 & 30 & 40 \\
\hline Invertase ácida & $\mathrm{ND}$ & 3833.5 & 10059.5 & 925.5 \\
Invertase neutra & $\mathrm{ND}$ & 4853.1 & 9127.3 & 2666.5 \\
Fosfofrutoquinase - ATP & 211.4 & 152.2 & 98.5 & $\mathrm{ND}$ \\
Fosfofrutoquinase - PPi & $\mathrm{ND}$ & 1750.3 & 714.9 & 414.3 \\
Sacarose sintase & 76.9 & 126.3 & 83.9 & 43.8 \\
Glicose 6-fosfato desidrogenase & 209.9 & 291.5 & 270.3 & 28.4 \\
UDPG pirofosforilase & 6655.9 & 7767.0 & 5128.6 & 3218.7 \\
Frutoquinase & 129.2 & 130.3 & 120.3 & 76.4 \\
Glicoquinase & 36.1 & 78.2 & 82.7 & 26.4 \\
Sorbitol desidrogenase & $\mathrm{ND}$ & $\mathrm{ND}$ & $\mathrm{ND}$ & $\mathrm{ND}$ \\
Aldose redutase & $\mathrm{ND}$ & $\mathrm{ND}$ & $\mathrm{ND}$ & $\mathrm{ND}$ \\
Glicerol 3-fosfato desidrogenase & 19.9 & 31.3 & $\mathrm{ND}$ & $\mathrm{ND}$ \\
Glicerol quinase & $\mathrm{ND}$ & 11.7 & $\mathrm{ND}$ & $\mathrm{ND}$ \\
Frutose 1,6 difosfatase & $\mathrm{ND}$ & 77.2 & 60.4 & $\mathrm{ND}$ \\
PROTEÍNA & 10.9 & 7.5 & 9.0 & 11.5 \\
\hline
\end{tabular}

$\mathrm{ND}=$ não detectável 
Tabela 4: Atividade específica ( $\mathrm{nmol} / \mathrm{min} \times \mathrm{mg}$ proteína) das enzimas do metabolismo de carboidratos e concentração protéica ( $\mu \mathrm{g} / \mathrm{mg}$ peso seco) em culturas de células em suspensão de Phaseolus vulgaris, crescendo em sacarose, nos dias $0,15,30$ e 40 .

\begin{tabular}{lllll}
\hline & \multicolumn{4}{c}{ TEMPO DE CRESCIMENTO (dias) } \\
\hline ENZIMAS & 0 & 15 & 30 & 40 \\
\hline Invertase ácida & 19.6 & 1017.0 & 1550.1 & 2939.4 \\
Invertase neutra & $\mathrm{ND}$ & 913.0 & 2064.3 & 2688.5 \\
Fosfofrutoquinase - ATP & 45.8 & 60.0 & 38.8 & 85.7 \\
Fosfofrutoquinase - PPi & $\mathrm{ND}$ & 482.6 & 213.7 & 365.3 \\
Sacarose sintase & $\mathrm{ND}$ & 89.2 & 104.5 & 202.5 \\
Glicose 6-fosfato desidrogenase & 284.0 & 163.8 & 330.3 & 231.3 \\
UDPG pirofosforilase & 1872.1 & 10855.3 & 6158.9 & 3034.1 \\
Frutoquinase & $\mathrm{ND}$ & 35.8 & 57.7 & 82.8 \\
Glicoquinase & $\mathrm{ND}$ & 38.6 & 79.6 & 99.6 \\
Sorbitol desidrogenase & $\mathrm{ND}$ & $\mathrm{ND}$ & $\mathrm{ND}$ & $\mathrm{ND}$ \\
Aldose redutase & $\mathrm{ND}$ & 11.0 & $\mathrm{ND}$ & 8.2 \\
Glicerol 3-fosfato desidrogenase & $\mathrm{ND}$ & 16.4 & 8.11 & $\mathrm{ND}$ \\
Glicerol quinase & $\mathrm{ND}$ & 7.1 & $\mathrm{ND}$ & $\mathrm{ND}$ \\
Frutose 1,6 difosfatase & $\mathrm{ND}$ & 60.6 & 68.3 & 77.9 \\
PROTEÍNA & 6.7 & 26.5 & 35.0 & 24.0 \\
\hline ND- não detectáv & & & &
\end{tabular}

$\mathrm{ND}=$ não detectável 
Com base nos resultados obtidos para as enzimas do metabolismo de carboidrato estudadas quando a sacarose foi empregada como fonte de carbono, podemos concluir que Curcuma e Phaseolus apresentam atividade das enzimas invertase, hexoquinase, sacarose sintase e UDP glicose pirofosforilase, o que indica que estas espécies metabolizam a sacarose utilizando as duas vias conhecidas (clássica e alternativa) de degradação. Por outro lado, em Bauhinia, onde foi detectada apenas atividade das enzimas invertase, hexoquinase e UDP glicose pirofosforilase, apenas a via clássica parece ocorrer.

A primeira via, conhecida como clássica, envolve a quebra da sacarose pela ação das invertases e posterior utilização dos produtos frutose e glicose pela frutoquinase e glicoquinase, com gasto de ATP, para a formação de frutose 6-fosfato e glicose 6fosfato, respectivamente (Sung et al., 1988). A segunda via, conhecida como alternativa, envolve a metabolização da sacarose pela sacarose sintase, com o consumo de uma molécula de uridina difosfato (UDP) e a formação de frutose e uridina difosfato glicose (UDPG) (Black et al., 1987). Para que esta última via ocorra, é necessário que uridina difosfato (UDP), uridina trifosfato (UTP) e pirofosfato inorgânico (PPi) sejam reciclados. A enzima chave para a produção de tais compostos é a uridina difosfato glicose pirofosforilase (UDPG pirofosforilase) que utiliza PPi para transformar UDPG em glicose 1-fosfato mais UTP (Black et al., 1987). O UTP formado é utilizado na reação de transformação de frutose em frutose 6-fosfato pela enzima frutoquinase que utiliza UTP. Nesta última reação é formado UDP que é novamente usado para a degradação da sacarose via sacarose sintase.

A enzima UDPG pirofosforilase necessita de uma fonte de PPi para expressar sua atividade. Alguns autores têm sugerido que a atividade da enzima fosfofrutoquinase dependente de PPi poderia gerar o PPi necessário para o funcionamento desta via alternativa (Huber \& Akazawa, 1986; Boll, 1991). Além disto, acredita-se que uma reserva de PPi está presente em células de plantas que apresentam concentrações citoplasmáticas de 0,04 a 0,80 mM (Sung et al, 1988).

Ainda não se sabe como ocorre a partição da sacarose entre as duas vias discutidas. Acredita-se que isto pode ocorrer em função da concentração de sacarose 
presente nas células (Huber \& Akazawa, 1986) ou do tipo e estágio de desenvolvimento do tecido (Sung et al, 1988).

Segundo Huber \& Akazawa (1986), como o Km da enzima sacarose sintase para a sacarose é menor do que as invertases, a via alternativa que envolve a sacarose sintase poderia ser importante quando a disponibilidade de sacarose se torna limitante. Além disto, esta via é mais eficiente energeticamente já que para cada molécula de sacarose metabolizada até triose-fosfato são gastos 3 ATP enquanto que na via clássica, que envolve as invertases este gasto é de 4 ATP (Huber \& Akazawa, 1986; Sung et al., 1988). Assim seria extremamente desejável para a célula que em condições limitantes de suprimento de carbono, uma via mais eficiente energeticamente ocorresse.

Sung et al. (1988) destacam que em tecidos onde o alongamento celular é ativo, predomina a atividade da invertase ácida, enquanto que em células dreno que armazenam sacarose ou amido, predomina a atividade da sacarose sintase. Portanto, em plantas, a atividade das três enzimas envolvidas na quebra da sacarose varia para tecidos e células específicas e estas variações estão fortemente relacionadas com o estágio de crescimento e função destes tecidos e células. Além disto, os autores destacam também que a presença do PPi e da via alternativa que envolve a sacarose sintase muda a produção energética da glicólise e da gliconeogênese. Desta forma as plantas adquirem sua habilidade única de responder dinamicamente à mudanças do meio ambiente, durante sua existência.

A deteç̧ão de atividade em níveis altos das invertases ácida e neutra, juntamente com a deteç̧ão da atividade da frutoquinase e da glicoquinase nas três espécies estudadas (Tabelas 2, 3 e 4), nos leva a propor o esquema da Figura 13 como a via de degradação da sacarose que ocorre em Bauhinia, Curcuma e Phaseolus.

Nesta via, a sacarose é quebrada pela ação da invertase em glicose e frutose que, juntamente com uma molécula de ATP, são transformadas em hexose 6-fosfato e ADP. Glicose 6-P passa a frutose 6-P pela ação da fosfoglicose isomerase e as duas moléculas de frutose 6-P formadas a partir da sacarose são então transformadas pela fosfofrutoquinase dependente de ATP ou PPi em 2 moléculas de frutose 1,6-bisfosfato + $2 \mathrm{ADP}$ ou $2 \mathrm{Pi}$. A frutose 1,6-bisfosfato formada sofre a ação da aldolase gerando triose- 
fosfato que segue a rota glicolítica até piruvato ou é desviada para a produção de aminoácidos e outras moléculas importantes para o metabolismo celular.

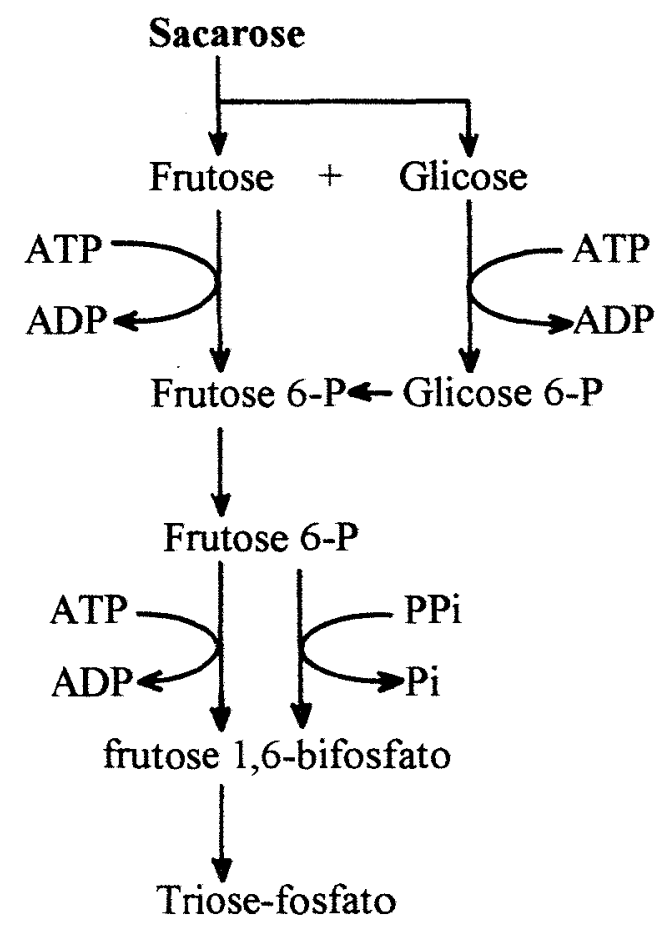

Figura 13-Via de degradação da sacarose proposta com base nos resultados obtidos na análise da atividade das enzimas do metabolismo de carboidratos em células em suspensão de Bauhinia, Curcuma e Phaseolus.

Devido à ausência da atividade da enzima sacarose sintase em Bauhinia (Tabela 2) e sua presença associada a alta atividade das enzimas UDPG pirofosforilase e fosfofrutoquinase dependente de PPi em Curcuma e Phaseolus (Tabelas 3 e 4), o esquema da via de degradação da sacarose da Figura 14 é proposto como também ocorrendo em Curcuma e Phaseolus. 


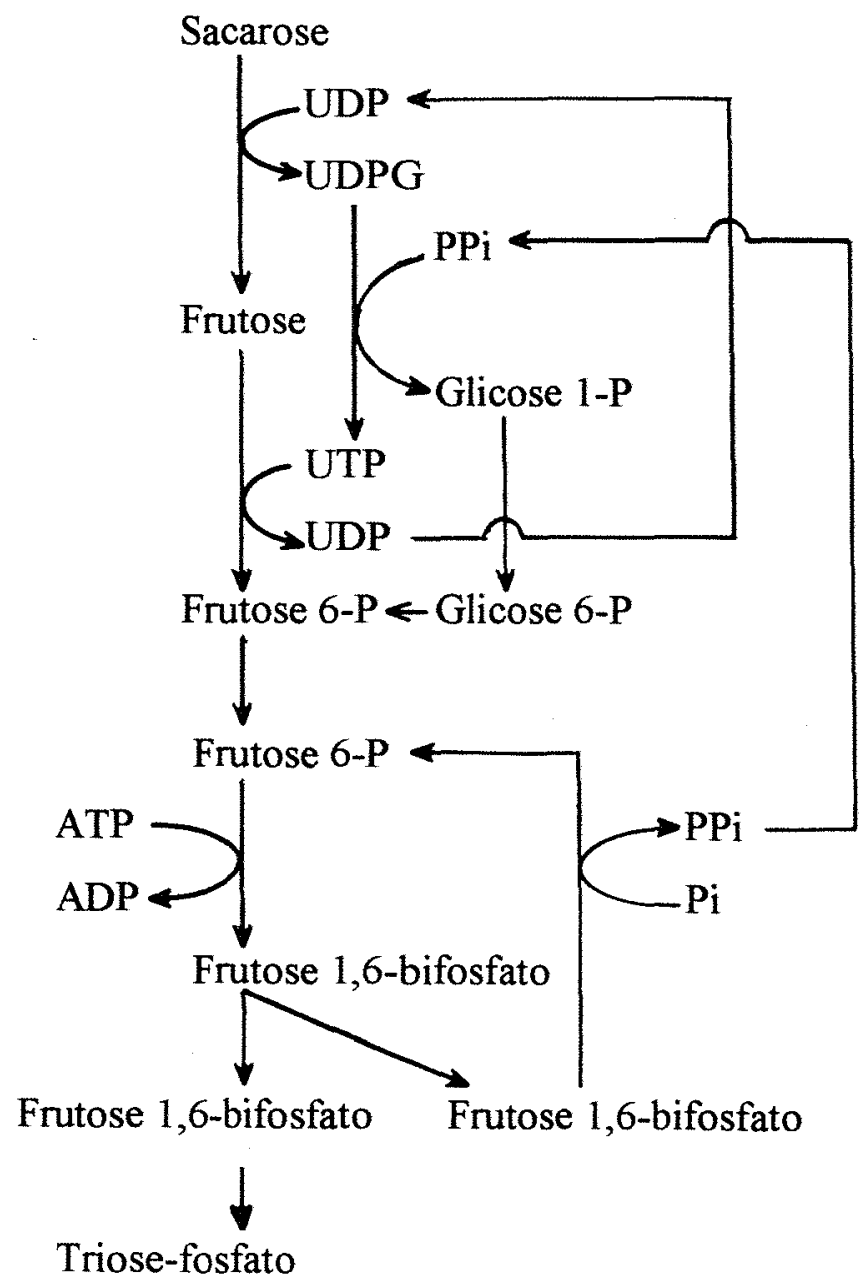

Figura 14: Via de degradação da sacarose proposta com base nos resultados obtidos na análise da atividade das enzimas do metabolismo de carboidratos em células em suspensão de Curcuma e Phaseolus.

Nesta via, a sacarose é quebrada pela ação da enzima sacarose sintase formando frutose e UDP glicose, com consumo de uma molécula de UDP. A UDP glicose formada é transformada em glicose 1-P + UTP, com consumo de um PPi, pela enzima UDP glicose pirofosforilase. A glicose 1-P e o UTP formados são utilizados para gerar, respectivamente, glicose 6-P pela ação da fosfoglicomutase e UDP + frutose 6-P a partir de frutose, pela ação da frutoquinase. O UDP gerado nesta reação pode ser reciclado na 
reação de quebra da sacarose pela sacarose sintase como descrito acima. A glicose 6-P formada é transformada em frutose 6-P pela ação da fosfoglicose isomerase e as duas moléculas de frutose 6-P geradas a partir da quebra da sacarose pela sacarose sintase sofrem ação da fosfofrutoquinase dependente de ATP gerando duas moléculas de frutose 1,6-bisfosfato. Uma molécula de frutose 1,6-bisfosfato é transformada em triose-fosfato pela ação da enzima aldolase enquanto a outra molécula volta a frutose 6-P pela ação da fosfofrutoquinase dependente de $\mathrm{Pi}$, gerando o PPi necessário na reação de conversão de UDP glicose a glicose 1-P descrita anteriormente.

Portanto, podemos concluir que enquanto as culturas de células em suspensão de Bauhinia forficata Link utilizam a sacarose fornecida no meio de cultura através da via de degradação da sacarose conhecida como clássica, as culturas de célula em suspensão de Curcuma zedoaria Roscoe e Phaseolus vulgaris utilizam a sacarose a elas fornecidas no meio de cultura tanto pela via de degradação da sacarose conhecida como clássica como pela via conhecida como alternativa.

A enzima sorbitol desidrogenase não foi detectada em nenhuma das culturas analisadas. Segundo Swedlund \& Locy (1993), culturas de calo de milho crescendo em sacarose ou sorbitol como fonte de carbono no meio de cultura apresentavam atividade da enzima sorbitol desidrogenase apenas quando os calos eram embriogênicos. Em calos não embriogênicos a atividade desta enzima não era detectada. Todas as culturas analisadas neste trabalho constituíam-se de células e microcalos não embriogênicos. A análise da sorbitol desidrogenase em culturas embriogênicas destas espécies estudadas poderiam confirmar os resultados obtidos em milho por Swedlund \& Locy (1993).

As enzimas do metabolismo do glicerol (glicerolquinase e glicerol 3-fosfato desidrogenase) apresentaram atividade baixa ou não detectável em todas as culturas de células estudadas. Frente a estes dados podemos sugerir que estas enzimas provavelmente sejam induzidas pelo substrato, não estejam presentes nas culturas estudadas ou ainda estejam presentes em quantidades muito baixas.

Diante da baixa atividade das enzimas glicerolquinase e glicerol 3-fosfato desidrogenase, que são responsáveis pelo metabolismo de glicerol em animais e microorganismos, sendo também esperadas serem responsáveis pelo metabolismo do 
glicerol em plantas, decidimos investigar a ocorrência deste metabolismo via formação do gliceraldeído como intermediário, pela ação da enzima aldose redutase.

Segundo Metzler (1977), em animais, frutose pode ser fosforilada por uma frutoquinase especial (cetohexoquinase) a frutose 1-P. Porém, não há uma mutase capaz de converter esta molécula em frutose 6-P. Ao invés, há uma aldose que quebra esta frutose 1-P a dihidroxi acetona fosfato e gliceraldeído. Este último pode ser metabolizado pela redução a glicerol pela ação da enzima aldose redutase (Figura 12), seguido pela fosforilação a glicerol-P pela glicerolquinase e reoxidação a dihidroxi acetona fosfato pela glicerol 3-P desidrogenase.

Toda a atenção voltada ao metabolismo do glicerol nas culturas das espécies estudadas se deve ao fato de que sob condições de parcial anaerobiose, como é o caso de cultura de células em suspensão, o NADH formado tem que regenerar o NAD necessário para a ocorrência das reações de oxidação da glicólise (Davies, 1980). Portanto acreditase que glicerol deve acumular nas células de culturas em suspensão sendo o seu metabolismo de formação via dihidroxi acetona fosfato ou gliceraldeido, responsáveis pela regeneração de NAD a partir de NADH. Embora fosse esperado a ocorrência de atividade significativa das enzimas que metabolizam glicerol, os resultados obtidos no presente trabalho em culturas de células em suspensão de plantas não foram conclusivos já que não foi detectada atividade mensurável destas enzimas. Outros trabalhos que explorem melhor a atividade das enzimas envolvidas na formação e degradação do glicerol necessitam ser realizados.

Embora as enzimas envolvidas no metabolismo da galactose não tenham sido analisadas neste estudo, espera-se que, principalmente em culturas de células de $C$. zedoaria que apresentaram aumento significativo de massa fresca e seca quando cultivadas nesta fonte de carbono, estas enzimas apresentem atividade em níveis adequados que possibilita os respectivos crescimentos e desenvolvimento das culturas. Tais considerações podem ser confirmadas com a análise da atividade destas enzimas nas suspensões celulares em questão.

Durante cultivo prolongado e sem transferèncias das culturas de células em suspensão, o meio de cultura se tornou pobre em carboidratos. Estas condições afetaram 
a atividade das enzimas estudadas conforme mostram os resultados das Tabelas 2,3 e 4 . Este resultado sugere a ocorrência de provável regulação pela concentração da fonte de carbono, no caso a sacarose, na atividade das enzimas da glicólise e gliconeogênese. Tais suposições foram primeiramente feitas por Boll (1991) quando o autor observou que a medida com que a sacarose do meio de cultura era consumida, a atividade das enzimas do metabolismo de carboidratos em culturas de células em suspensão de Picea abies diminuía.

Baseado nos resultados aqui apresentados, acredita-se que o estudo das enzimas do metabolismo de carbono em cultura de células em suspensão de plantas crescendo em outras fontes de carbono ou em combinações de diferentes fontes de carbono, poderia esclarecer muitas das questões surgidas durante a interpretação dos resultados. A ocorrência de vias metabólicas pelas quais as fontes alternativas de carbono são aproveitadas por culturas de células em suspensão de plantas, a ativação de rotas alternativas, a regulação do metabolismo por estas fontes e outros aspectos, ainda necessitam ser confirmados, o que abre caminho para novas pesquisas na área. 


\section{5- CONCLUSÕES}

Baseando-se nos resultados obtidos concluiu-se que:

A sacarose foi a fonte de carbono que proporcionou o maior crescimento em biomassa para as três espécies estudadas.

A galactose mostrou ser uma fonte alternativa de carbono potencial para o cultivo de células em suspensão de Curcuma zedoaria Roscoe e Bauhinia forficata Link.

O glicerol se destacou no cultivo de células em suspensão de Bauhinia forficata Link, mostrando sua potencialidade em ser utilizado por células desta espécie.

Segundo a análise das enzimas do metabolismo de carboidratos, o modo de aproveitamento da sacarose como fonte de carbono parece ser dependente da espécie de planta.

A ausência em Bauhinia e a presença em Curcuma e Phaseolus da enzima sacarose sintase evidencia a ocorrência de duas vias do metabolismo da sacarose nas plantas estudadas. Enquanto a sacarose fornecida no meio de cultura é aproveitada pelas células de Bauhinia somente através da via clássica, as células de Curcuma e Phaseolus utilizam a sacarose através das duas vias de degradação conhecidas, a via clássica e a via alternativa. 


\section{REFERÊNCIAS BIBLIOGRÁFICAS}

BABU, K.N.; SAMSUDEEN, K.; RATNAMBAL, M.J. In vitro plant regeneration from leaf-derived callus in ginger (Zingiber officinales Rosc.). Plant Cell, Tissue and Organ Culture, v.29, p.71-74, 1992.

BARROS, L.M.G.; GAMA, M.I.C.S.; GONÇALVES, C.H.R.P.; BARRETO, C.C.; SANTANA, E.F.; CARNEIRO, V.T.C. Cultura de tecidos de feijoeiro visando a introdução de genes exógenos. Pesquisa Agropecuária Brasileira, v.32, n.3, p.267275, 1997.

BARTHAKUR, M.P.; BORDOLOI, D.N. Micropropagation of Curcuma amada. Journal of Spices and Aromatic Crops, v. 1, n.2, p.154-159, 1992.

BEEVERS, H. The role of the glyoxylate cycle. In: STUMPF, P.K.; CONN, E.E. (Ed.) The Biochemistry of Plants. New York: Academis Press, 1980. Cap.4, p.117-130.

BELYANSKAYA, S.L.; SHAMINA, Z.B.; KUCHERENKO, L.A . Morphogenesis in stress-resistant rice clones. Russian Journal of Plant Physiology, v.41, n.4, p.503506, 1994./Resumo em CAB Abstract on CD-ROM, 1998/

BERGER, K.; SCHAFFNER, W. In vitro propagation of the leguminous tree Swartzia madagascariensis. Plant Cell, Tissue and Organ Culture, v.40, p.289-291, 1995. 
BIELESKI, R.L. Sugar Alcohols. In: LOEWUS, F.A .; TANNER, W. Encyclopedia of Plant Physiology. Berlin: Springer-Verlag, 1982, v.13A, p. 158-192.

BLACK, C.C.; MUSTARDY, L.; SUNG, S.S.; KORMANIK, P.P.; XU, D.P.; PAZ, N. Regulation and roles for alternative pathways of hexose metabolism in plants. Physiologia Plantarum, v.69, p.387-394, 1987.

BOLL, M. Activities and regulation of enzymes of carbohydrate metabolism in spruce (Picea abies). Z. Naturforsch., v.46c, p.597-604, 1991.

BRADFORD, M.M. A rapid and sensitive method for the quantitation of microgram quantities of protein utilizing the principle of protein-dye binding. Analytical Biochemistry, v.72, p.248-54, 1976.

BROETTO, F.; LIMA, G.P.P.; BRASIL, O .G. Tolerância à salinidade em feijão. Scientia Agrícola, v.52, n.1, p.164-166, 1995.

BORKOWSKA, B.; SZCZERBA, J. Influence of different carbon sources on invertase activity and growth of sour cherry (Prunus cerasus L.) shoot cultures. Journal of Experimental Botany, v.42, n.240, p.911-915, July 1991.

CABASSON, C.; OLlitraulT, P.; CÔTE, F.X.; MICHAUX-FERRIÈRE, N.; DAMBIER, D.; DALNIC, R.; TEISSON, C. Characteristics of Citrus cell cultures during undifferentiated growth on sucrose and somatic embryogenesis on galactose. Physiologia Plantarum, v.93, p.464-470, 1995.

CARNAL, N.W.; BLACK, C.C. Phosphofructokinase activities in photosynthetic organisms. Plant Physiology, v.71, p.150-155, 1983. 
CARVALHO, R.N. Cultivo in vitro de Bauhinia forficata Link. Piracicaba, 1998. 51p. Dissertação (M.S.) - Escola Superior de Agricultura "Luiz de Queiroz", Universidade de São Paulo.

COLEMAN, G.D.; ERNST, S.G. Axillary shoot proliferation and growth of Populus deltoides shoot cultures. Plant Cell Reports, v.9, p.165-167, 1990.

COPELAND, L.; VELLA, J.; HONG, Z. Enzymes of carbohydrate metabolism in soybean nodules. Phytochemistry, v.28, n.1, p.57-61, 1989.

COUILLEROT, J.P.; DECOUT, E.; WARNOT, F.; DUBOIS, J.; VASSEUR, J. Free polyamines evolution in relation to carbohydrate sources and somatic embryogenesis in a Cichorium hybrid. Sciences de la Vie, v.316, n.3, p.299-305, 1993.

DAVIES, D.D. Anaerobic metabolism and production of organic acids. In: STUMPF, P.K., CONN, E.E. (Ed.) The Biochemistry of Plants - A comprehensive Treatise. New York: Academic Press, 1980. v.2, cap. 13, p.581-611.

DEKKERS, A .J.; RAO, A .N.; GOH, C.J. In vitro storage of multiple shoot cultures of gingers at ambient temperature of $24-29^{\circ} \mathrm{C}$. Scientia Horticulturae, v. 47 , p. 157-167, 1991.

DENG, Z.A .; ZHANG, W.C.; WAN, S.Y. Induction of somatic embryogenesis from habituated calluses in Citrus. Journal of Fruit Science, v.8, n.4, p.193-200, 1991.

DETREZ, C.; NDIAYE, S.; DREYFUS, B. In vitro regeneration of the tropical multipurpose leguminous tree Sesbania grandiflora from cotyledon explants. Plant Cell Reports, v.14, p.87-93, 1994. 
DILlEN, W.; De-ClERCQ, J.; Van-MONTAGU, M.; ANGENON, G. Plant regeneration from callus in a range of Phaseolus acutifolius A. Gray genotypes. Plant Science Limerick, v.118, n.1, p.81-88, 1996. /Resumo em CAB Abstracts on CD-ROM, 1998/

DOEHLERT, D.C.; KUO, T.M.; FELKER, F.C. Enzymes of sucrose and hexose metabolism in developing kernels of two inbreds of maize. Plant Physiology, v.86, p.1013-1019, 1988.

DOGRA, S.P.; KORLA, B.N.; SHARMA, P.P. In vitro clonal propagation of ginger (Zingiber officinales Rosc.). Horticultural Journal, v.7, n.1, p.45-50, 1994.

FERNANDEZ-CASO, M.; PELAEZ, M.I.; RUIZ, M.L. Onset of in vitro morphogenic response and protein pattern changes in Phaseolus vulgaris L. Journal of Plant Physiology, v.149, p.757-761, 1996.

FRICK, H. Heterotrophy in the Lemnaceae. Journal of Plant Physiology, v.144, p. 189193, 1994.

FRICK, H.; MORLEY, K. Metabolism of lactose by Lemna minor L. (Duckweed) callus. Process Biochemistry, v.30, n.1, p.57-62, 1995.

GALLO, L.A. Estudo do metabolismo do nitrogênio em embriões de feijão cultivados in vitro. São Paulo, 1994. 150p. Tese (Doutorado) - Instituto de Química, Universidade de São Paulo.

GAVISH, H.; VARDI, A .; FLUHR, R. Suppresion of somatic embryogenesis in Citrus cell cultures by extracellular proteins. Planta, v.186, n.4, p.511-517, 1992. 
GODO, T.; MATSUI, K.; KIDA, T.; MII, M. Effect of sugar type on the efficiency of plant regeneration from protoplasts isolated from shoot tip-derived meristematic nodular cell clumps of LiliumXformolongi hort. Plant Cell Reports, v.15, p.401-404, 1996.

GOODWIN, T.W.; MERCER, E.I. Introduction to Plant Biochemistry. New York: Pergamon Press, 1983. 677p.

GROUT, B.W.W.; CHAN, K. W.; SIMPKINS, I. Aspects of growth and metabolism in a suspension culture of Acer pseudoplatanus (L.) grown on a glycerol carbon source. Journal of Experimental Botany, v.27, n.96, p.2-11, 1976.

GRUNNET, N.; LUNDQUIST, F. Kinetics of glycerol kinase from mammalian liver and Candida mycoderma. European Journal of Biochemistry, v.3, p.78-84, 1967.

HARADA, H.; MURAI, Y. Micropropagation of Prumus mume. Plant Cell Tissue and Organ Culture, v.46, p.265-267, 1996.

HAMMATT, N. Micropropagation of fastigiate bird cherry (Prunus padus L.) and adventitious shoot formation from leaves. Journal of Horticultural Science, v.68, n.6, p.975-981, 1993.

HELLEBOID, S.; COUILLEROT, J.P.; VASSEUR, J. Inhibition of direct embryogenesis by alpha-difluoromethylarginine in a Cichorium hybrid: effect on polyamine content and protein patterns. Planta, v.196, n.3, p.571-576, 1995.

HUBER, S.C. Fructose 2,6-bisphosphate as a regulatory metabolite in plants. Annual Review of Plant Physiology, v.37, p.233-246, 1986. 
HUBER, S.C.; AKAZAWA, T. A novel sucrose synthase pathway for sucrose degradation in cultured sycamore cells. Plant Physiology, v.81, p.1008-1013, 1986.

HUNG, J.H. In vitro propagation and preservation of ginger germplasm resouces. Scientia Agricultura Sinica, v.28, n.2, p.24-30, 1995.

ILLG, R.D.; FARIA, R.T. Micropropagation of Alpinia purpurata from inflorescence buds. Plant Cell, Tissue and Organ Culture, v.40, p.183-185, 1995.

JAIN, R.K.; DAVEY, M.R.; COCKING, E.C.; WU, R. Carbohydrate and osmotic requirements for high-frequency plant regeneration from protoplast-derived colonies of indica and japonica rice varieties. Journal of Experimental Botany, v.48, n.308, p.751-758, March 1997.

JONES, A .; VELIKY, I.A . Growth of plant cell suspension cultures on glycerol as a sole source of carbon and energy. Canadian Journal of Botany, v.58, p.648-657, 1980.

JOURNET, E.P.; DOUCE, R. Enzymic capacities of purified cauliflower bud plastids for lipid synthesis and carbohydrate metabolism. Plant Physiology, v.79, p.458-467, 1985.

KACKAR, A .; BHAT, S.R.; CHANDEL, K.P.S.; MALIK, S.K. Plant regeneration via somatic embryogenesis in ginger. Plant Cell, Tissue and Organ Culture, v.32, p.289-292, 1993.

KAHM, A . Use of myo-inositol as a carbon source for the induction of tracheary elements in Citrus fruit. Indian Journal of Experimental Biology, v.33, n.8, p.600603, 1995. /Resumo em CAB Abstracts on CD-ROM, 1998/ 
KAO, K.N.; MICHAYLUK, M.R. Nutricional requirements for growth of Vicia hajastana cells and protoplasts at a very low population density in liquid medium. Planta, v. 126, p.105-110, 1975.

KARHU, S.T. Sugar use in relation to shoot induction by sorbitol and cytokinin in apple. Journal of the American Society for Horticultural Science v.122, n.4, p.476-480, 1997.

KINNERSLEY, A .M.; HENDERSON, W.E. Alternative carbohydrates promote differentiation of plant cells. Plant Cell, Tissue and Organ Culture, v.15, p.3-16, 1988.

KOZAI, T. Micropropagation under photoautotrophic conditions. In: DEBERGH, P.C.; ZIMMERMANN, R.H. (Ed.). Micropropagation: Technology and Aplication, Dordrecht: Kluwer Academic Publishers, 1991. P.447-469.

KUMAR, A .; TANDON, P.; SHARMA, A . Morphogenetic responses of cultured cells of cambial origin of a mature tree- Dalbergia sissoo Roxb. Plant Cell Reports, v.9, p.703-706, 1991.

KUMAR, A . Micropropagation of a mature leguminous tree-Bauhinia purpurea. Plant Cell, Tissue and Organ Culture, v.31, p.257-259, 1992.

KUNITAKE, H.; IMAMIZO, H.; MII, M. Somatic embryogenesis and plant regeneration from immature seed-derived calli of rugosa rose (Rosa rugosa Thumb.). Plant Science Limerick, v.90, n.2, p.187-194, 1993.

LEHNINGER, A .L.; NELSON, D.L.; COX, M.M. Principles of Biochemistry. New York: Worth Publishers, 1993. 1013p. 
LEIFERT, C.; MURPHY, K.P.; LUMSDEN, P.J. Mineral and carbohydrate nutrition of plant cell and tissue cultures. Critical Reviews in Plant Science, v.14, n.2, p.83-109, 1995.

LEMOS, E.E.P.; BLAKE, J. Micropropagation of juvenile and mature Annona muricata L. Journal of Horticultural Science, v.71, n.3, p.395-403, 1996a.

LEMOS, E.E.P.; BLAKE, J. Micropropagation of juvenile and adult Annona squamosa. Plant Cell, Tissue and Organ Culture, v.46, p.77-79, 1996b.

LOESCHER, W.H. Physiology and metabolism of sugar alcohols in higher plants. Physiologia Plantarum, v.70, p.553-557, 1987.

LORENZO, J.C.; GARCIA, G.; ESCALONA, M.; DAQUINTA, M.A ; CASTLLO, R.; FUNDORA, Z.; BORROTO, C.G. In vitro somatic embryogenesis in Cleopatra mandarin (Citrus reshni Hort. Ex. Tan.). Centro Agrícola, v.21, n.3, p.85-91, 1994.

MALIK, K.A ; SAXENA, P.K. Somatic embryogenesis and shoot regeneration from intact seedlings of Phaseolus acutifolius A ., P. aureus (L.) Wilczek, P. coccineus L., and $P$. wrightii L. Plant Cell Reports, v. 11, p. 163-168, 1992.

MARETZKI, A .; THOM, M. Characteristics of a galactose-adapted sugarcane cell line grown in suspension culture. Plant Physiology, v.61, p.544-548, 1978.

MARINO, G.; BERTAZZA, G.; MAGNANINI, E.; ALTAN, A .D. Comparative effects of sorbitol and sucrose as main carbon energy sources in micropropagation of apricot. Plant Cell Tissue and Organ Culture, v.34, n.3, p.235-244, 1993. 
MATHUR, J.; MUKUNTHAKUMAR, S. Micropropagation of Bauhinia variegata and Parkinsonia aculeata from nodal explants of mature trees. Plant Cell, Tissue and Organ Culture, v.28, p.119-121, 1992.

MESSNER, B.; BERNDT, J. Ascorbic acid and chlorophyll content in cell cultures of Spruce (Picea abies): changes by cell culture conditions and air pollutants. Verlag der Zeitschrift fur Naturforschung, v.45c, p. 614-620, 1990/Resumo em CAB Abstracts on CD-ROM, 1993/

METZLER, D.E. Biochemistry - The chemical reactions of living cells. New York: Academic Press, 1977. 1129p.

MIACHIR, J.I. Proposição de um protocolo de cultura de tecidos para produção de compostos secundários para Curcuma zedoaria Roscoe. Piracicaba, 1992.126p. Dissertação (M.S.) - Escola Superior de Agricultura "Luiz de Queiroz", Universidade de São Paulo.

MONROY, M.R.; APARICIO, A .J.; ORTÍZ, G.D.; JIMÉNEZ, G.S. Effect of carbon source on cell growth and betalain production in cell suspension culture of Beta vulgaris. Biotchnology Letters, v. 16, n.8, p.853-858, 1994.

MURAI, Y.; HARADA, H.; TAKAGI, T. In vitro shoot and root proliferation in flowering mune cultivars. Journal of the Japanese Society for Horticultural Science, v.65, n.1, p.155-159, 1996./Resumo em CAB Abstracts on CD-ROM, $1998 /$

MURALITHARAN, M. S.; CHANDLER, S.F.; STEVENINCK, R.F.M. Physiological adaptation to high ion concentrations or water deficit by callus cultures of highbush blueberry, Vaccinium corymbosum. Australian Journal of Plant Physiology, v.20, p.159-172, 1993. 
MURASHIGE, T.; SKOOG, F. 1962. A revised medium for rapid growth and bioassays with tobacco tisuue cultures. Physiologia Plantarum, 15: 473-97.

MURTHY, B.N.S.; VICTOR, J.; SINGH, R.P.; FLETCHER, R.A .; SAXENA, P.K. In vitro regeneration of chickpea (Cicer arietimum L.): Stimulation of direct organogenesis and somatic embryogenesis by thidiazuron. Plant Growth Regulation, v.19, p.233-240, 1996.

NAVARRO-ALVAREZ, W.; BAENZIGER, P.S.; ESKRIDGE, K.M.; SHELTON, D.R.; GUSTAFSON, V.D.; HUGO, M. Effect of sugars in wheat anther culture media. Plant Breeding, v.112, n.1, p.53-62, 1994.

NIELSEN, T.H. Fructose-1,6-bisphosphate is na allosteric activator of pyrophosphate: fructose 6-phosphate 1-phosphotransferase. Plant Physiology, v.108, p.69-73, 1995.

OKAZAKI, K.; KOIZUMI, M.; NISHIO, T.; DORE, C. Callus formation and regeneration of some species of Lilium. Acta Horticulturae, v.392, p.97-106, 1995.

OKEZIE, C.E.A ; OKONKWO, S.N.C.; NWOKE, F.I.O . Carbon source requirement for the culture of white yam (Dioscorea rotunda) embryos in vitro. Acta Horticulturae, v.380, p.329-334, 1994.

PLAXTON, W.C. The organization and regulation of plant glycolysis. Annual Review of Plant Physiology and Plant Molecular Biology, v.47, p.185-214, 1996.

RACKER, E. Fructose 1,6-diphosphatase from spinach leaves. In: COLOWICK, S.P.; KAPLAN, N.O (Ed.) . Methods in Enzymology, New York : Academic Press, 1962. v. 5 , p. $272-276$. 
RAGHAVAN, V. Biochemistry of somatic embryogenesis. In: EVANS, D. A ., SHARP, W.R.; AMIRATO, P.V.; YAMADA, Y. (Ed.). Handbook of Plant Cell Culture,

ROBATCHE-CLAIVE, A .S.; COULLEROT, J.P.; DUBOIS, T.; VASSEUR, J. Direct somatic embryogenesis in leaves of the Cichorium hybrid ' 474 ', synchronization of the induction stage. Science de la Vie, v.314, n.8, p.371-377, 1992.

ROBERTS, L.W.; BABA, S. Glycerol and myo-inositol as carbon sources for the induction of xylogenesis in explants of Lactuca. Canadian Journal of Botany, v.60, p.1204-1206, 1982.

ROKEM, J.S.; TAL, B.; GOLDBERG, I. Methods for increasing diosgenin production by Dioscorea cells in suspension cultures. Journal of Natural Products, v.48, n.2, p.210-222, 1985.

ROMANO, A ; NORONHA, C.; MARTINS-LOUÇÃO, M.A . Role of carbohydrates in micropropagation of cork oak. Plant Cell Tissue and Organ Culture, v.40, n.2, p.159-167, 1995.

SAMYN, G. Influence of type and concentration of the C-source on the propagation by axillary branching of the tropical aquatic plant Peplis diandra Nutt. Ex DC. Bulletin des Recherches Agronomiques de Gembloux, v.30, n. 1-2, p.59-65, 1995.

SCHULLER, A .; REUTHER, G. Response of Abies alba embryonal-suspensor mass to various carbohydrate treatments. Plant Cell Reports, v.12, n.4, p.199-202, 1993.

SCRAGG, A .H.; ALLAN, E.J. Production of the triterpenoid quassin in callus and cell suspension cultures of Picrasma quassioides Benett. Plant Cell Reports, v.3, p.336$339,1986$. 
SIDOROVICH, E.A ; KUTAS, E.N.; FILIPENYA, V.L. Effects of osmotic inhibitors on maintenance of variability in introduced varieties of Vaccinium corymbosum $\mathrm{L}$. and Vaccinium vitis-ideae L. in vitro culture. Doklady Akademii Nauk Belarusi, v.39, n.1, p.63-66, 1995./Resumo em CAB Abstracts on CD-ROM, 1998/

SINGH, A .K.; NITO, N.; IWAMASA, M.; SUBHADRABANDHU, S. Influence of lactose and glycerol on growth and somatic embryogenesis of citrus callus. Acta Horticulturae, v.321, p. 606-609, 1992.

SPIEGEL-ROY, P.; SAAD, S. Regeneration from salt tolerant callus in Citrus. Advances in Horticultural Science, v.11, n.1, p.3-9, 1997. /Resumo em CAB Abstracts on CD-ROM, 1998/

STRICKLAND, S.G.; NICHOL, J.W.; McCALL, C.M.; STUART, D.A . Effect of carbohydrate source on alfafa somatic embryogenesis. Plant Science, v.48, p.113$121,1987$.

SUNG, S.S.; XU, D.P.; GALLOWAY, C.M.; BLACK, C.C. A reassessment of glycolysis and gluconeogenesis in higher plants. Physiologia Plantarum, v.72, p.650-654, 1988.

SUNG, S.S.; KORMANIK, P.P.; XU, D.P.; BLACK, C.C. Sucrose metabolic pathways in sweetgum and pecan seedlings. Tree Physiology, v.5, p.39-52, 1989.

SUNG, S.S.; Kormanik, P.P.; BLACK, C.C. Understanding sucrose metabolism and growth in a developing sweetgum plantation. In: SOUTHERN FOREST TREE IMPROVEMENT CONFERENCE, 22 ${ }^{\text {nd }}$, Atlanta-Georgia, 1993. Southern Forest Tree Improvement Committee, 1993, p. 114-123. 
SWEDLUND, B.; LOCY, R.D. Sorbitol as the primary carbon source for the growth of embryogenic callus of maize. Plant Physiology, v.103, p.1339-1346, 1993.

THOMPSON, M.; THORPE, T. Metabolic and non-metabolic roles of carbohydrates. In: BONGA, J.M.; DURZAN, D.J. (Ed.) Cell and Tissue Culture in Forestry, Dordrecht: Martinus Nijhoff Publishers, 1987. P. 89-112.

TSUKAHARA, M.; HIROSAWA, T.; KISHINE, S. Efficient Plant Regeneration from Cell Suspension Cultures of Rice (Oryza sativa L.). Journal of Plant Physiology, v.149, p.157-162, 1996.

UPRETI, J.; DHAR, U. Micropropagation of Bauhinia vahlii Wight \& Arnott-a leguminous liana. Plant Cell Reports, v.16, p.250-254, 1996.

VU, J.C.V.; NIEDZ, R.P.; YELENOSKY, G. Glycerol stimulation of chlorophyll synthesis, embryogenesis, and carboxylation and sucrose metabolism enzymes in nucellar callus of 'Hamlin' sweet orange. Plant Cell, Tissue and Organ Culture, v.33, p. $75-80,1993$.

VU, J.C.V.; NIEDZ, R.P.; YELENOSKY, G. Activities of sucrose metabolism enzymes in glycerol-grown suspension cultures of sweet orange (Citrus sinensis L. Osbeck). Environmental and Experimental Botany, v.35, n.4, p.455-463, 1995.

XU, D.P.;SUNG, S.S.; ALVAREZ, C.A ; BLACK, C.C. Pyrophosphate-dependent sucrose metabolism and its activation by fructose 2,6 bisphosphate in sucrose importing plant tissue. Biochemical and Biophysical Research Communications, v. 141, n. 2, p. $440-445,1986$.

XU, D.P.; Sung, S.S.; BLACK, C.C. Sucrose metabolism in lima bean seeds. Plant Physiology, v.89, p.1106-1116, 1989. 
WELANDER, M.; WELANDER, N.T.; BRACKMAN, A .S. Regulation of in vitro shoot multiplication in Syringa, Almus and Malus by different carbon sources. Journal of Horticultural Science, v.64, n.3, p.361-366, 1989.

YOSHIDA, K.T.; FUII, S.; SAKATA, M.; TAKEDA, G. Control of organogenesis and embryogenesis in rice calli. Breeding Science, v.44, n.4, p.355-360, 1994.

ZAMSKI, E; WYSE, R.E. Stereospecificity of the glucose carrier in sugar beet suspension cells. Plant Physiology, v.78, p.291-295, 1985.

ZIMMERMANN, M.H.; ZIEGLER, H. List of sugar alcohols in sieve-tube exudates. In: ZIMMERMANN, M.H.; MILBURN, J. A .(Ed.) Encyclopedia of Plant Physiology New Series. Berlin: Springer-Verlag, 1975. v.1, p.480-503. 
APÊNDICE 
Tabela A1: Efeito de diferentes fontes de carbono no ganho de massa fresca (g) por células em suspensão de Bauhinia forficata Link.

\begin{tabular}{lllll}
\hline \multicolumn{5}{c}{ Fontes de carbono } \\
\hline $\begin{array}{c}\text { Tempo de } \\
\text { crescimento } \\
\text { (dias) }\end{array}$ & Sacarose & Sorbitol & Galactose & Glicerol \\
\hline 0 & 0,500 & 0,500 & 0,500 & \\
5 & 0,490 & 0,464 & 0,458 & 0,500 \\
10 & 0,643 & 0,533 & 0,512 & 0,427 \\
15 & 0,940 & 0,627 & 0,571 & 0,443 \\
20 & 1,113 & 0,540 & 0,502 & 0,444 \\
25 & 0,750 & 0,610 & 0,541 & 0,474 \\
30 & 1,128 & 0,376 & 0,514 & 0,367 \\
35 & 1,432 & 0,507 & 0,487 & 0,417 \\
40 & 1,928 & 0,555 & 0,588 & 0,576 \\
45 & 1,640 & 0,402 & 0,493 & 0,539 \\
\hline
\end{tabular}

$$
\text { c.v. }=5,46
$$

Tabela A2: Efeito de diferentes fontes de carbono no ganho de massa fresca (g) por células em suspensão de Curcuma zedoaria.

\begin{tabular}{lllll}
\hline \multicolumn{5}{c}{ Fontes de carbono } \\
\hline $\begin{array}{c}\text { Tempo de } \\
\text { rescimento } \\
\text { (dias) }\end{array}$ & Sacarose & Sorbitol & Galactose & Glicerol \\
\hline 0 & 0,500 & 0,500 & 0,500 & \\
5 & 0,576 & 0,498 & 0,505 & 0,500 \\
10 & 0,876 & 0,561 & 0,488 & 0,436 \\
15 & 1,093 & 0,521 & 0,572 & 0,455 \\
20 & 1,847 & 0,547 & 0,532 & 0,430 \\
25 & 3,887 & 0,548 & 0,519 & 0,366 \\
30 & 3,703 & 0,516 & 0,614 & 0,403 \\
35 & 5,426 & 0,462 & 0,952 & 0,329 \\
40 & 6,147 & 0,422 & 0,799 & 0,380 \\
45 & 3,482 & 0,526 & 0,997 & 0,397 \\
\hline
\end{tabular}

c.v. $=\mathbf{8 , 2 1}$ 
Tabela A3: Efeito de diferentes fontes de carbono no ganho de massa fresca (g) por células em suspensão de Phaseolus vulgaris.

\begin{tabular}{|c|c|c|c|c|}
\hline & \multicolumn{4}{|c|}{ Fontes de carbono } \\
\hline $\begin{array}{l}\text { Tempo de } \\
\text { crescimento } \\
\text { (dias) }\end{array}$ & Sacarose & Sorbitol & Galactose & Glicerol \\
\hline 0 & 0,500 & 0,500 & 0,500 & 0,500 \\
\hline 5 & 0,465 & 0,408 & 0,389 & 0,340 \\
\hline 10 & 0,460 & 0,396 & 0,309 & 0,422 \\
\hline 15 & 1,109 & 0,363 & 0,303 & 0,300 \\
\hline 20 & 1,186 & 0,400 & 0,367 & 0,295 \\
\hline 25 & 6,293 & 0,397 & 0,324 & 0,371 \\
\hline 30 & 3,043 & 0,324 & 0,186 & 0,184 \\
\hline 35 & 7,824 & 0,407 & 0,259 & 0,261 \\
\hline 40 & 4,912 & 0,278 & 0,289 & 0,187 \\
\hline 45 & 9,545 & 0,321 & 0,384 & 0,289 \\
\hline
\end{tabular}

$$
\text { c.v. }=9,31
$$

Tabela A4: Efeito de diferentes fontes de carbono no ganho de massa seca (g) por células em suspensão de Bauhinia forficata Link.

\begin{tabular}{|c|c|c|c|c|}
\hline & \multicolumn{4}{|c|}{ Fontes de carbono } \\
\hline $\begin{array}{l}\text { Tempo de } \\
\text { crescimento } \\
\text { (dias) }\end{array}$ & Sacarose & Sorbitol & Galactose & Glicerol \\
\hline 0 & 0,060 & 0,060 & 0,060 & 0,060 \\
\hline 5 & 0,049 & 0,057 & 0,059 & 0,066 \\
\hline 10 & 0,065 & 0,065 & 0,065 & 0,074 \\
\hline 15 & 0,099 & 0,071 & 0,073 & 0,074 \\
\hline 20 & 0,118 & 0,063 & 0,069 & 0,071 \\
\hline 25 & 0,084 & 0,075 & 0,075 & 0,077 \\
\hline 30 & 0,127 & 0,041 & 0,068 & 0,056 \\
\hline 35 & 0,153 & 0,060 & 0,068 & 0,066 \\
\hline 40 & 0,197 & 0,062 & 0,081 & 0,099 \\
\hline 45 & 0,150 & 0,047 & 0,063 & 0,086 \\
\hline
\end{tabular}

$$
\text { c.v. }=\mathbf{8 , 5 6}
$$


Tabela A5: Efeito de diferentes fontes de carbono no ganho de massa seca (g) por células em suspensão de Curcuma zedoaria Roscoe.

\begin{tabular}{lllll}
\hline \multicolumn{4}{c}{ Fontes de carbono } \\
\hline $\begin{array}{c}\text { Tempo de } \\
\text { rescimento } \\
\text { (dias) }\end{array}$ & Sacarose & Sorbitol & Galactose & Glicerol \\
\hline 0 & 0,026 & 0,026 & 0,026 & \\
5 & 0,036 & 0,051 & 0,044 & 0,026 \\
10 & 0,058 & 0,061 & 0,047 & 0,055 \\
15 & 0,077 & 0,050 & 0,053 & 0,060 \\
20 & 0,116 & 0,050 & 0,051 & 0,053 \\
25 & 0,219 & 0,051 & 0,053 & 0,047 \\
30 & 0,188 & 0,043 & 0,058 & 0,050 \\
35 & 0,233 & 0,044 & 0,079 & 0,043 \\
40 & 0,167 & 0,038 & 0,069 & 0,037 \\
45 & 0,122 & 0,042 & 0,083 & 0,040 \\
\hline
\end{tabular}

c.v. $=11,43$

Tabela A6: Efeito de diferentes fontes de carbono no ganho de massa seca (g) por células em suspensão de Phaseolus vulgaris.

\begin{tabular}{lllll}
\hline \multicolumn{5}{c}{ Fontes de carbono } \\
\hline $\begin{array}{c}\text { Tempo de } \\
\text { crescimento } \\
\text { (dias) }\end{array}$ & Sacarose & Sorbitol & Galactose & Glicerol \\
\hline 0 & 0,035 & 0,035 & 0,035 & \\
5 & 0,042 & 0,038 & 0,044 & 0,035 \\
10 & 0,031 & 0,036 & 0,028 & 0,053 \\
15 & 0,066 & 0,033 & 0,029 & 0,054 \\
20 & 0,077 & 0,040 & 0,034 & 0,035 \\
25 & 0,685 & 0,037 & 0,028 & 0,047 \\
30 & 0,765 & 0,029 & 0,020 & 0,020 \\
35 & 0,311 & 0,036 & 0,028 & 0,035 \\
40 & 0,398 & 0,031 & 0,024 & 0,023 \\
45 & 0,393 & 0,030 & 0,030 & 0,031 \\
\hline
\end{tabular}

c.v. $=13,79$ 
Tabela A7 : Efeito de diferentes fontes de carbono na concentração de proteína ( $\mu \mathrm{g}$ proteína/mg peso seco) de células em suspensão de Bauhinia forficata Link..

\begin{tabular}{lllll}
\hline \multicolumn{4}{c}{ Fontes de carbono } \\
\hline $\begin{array}{c}\text { Tempo de } \\
\text { crescimento } \\
\text { (dias) }\end{array}$ & Sacarose & Sorbitol & Galactose & Glicerol \\
\hline 0 & 2,31 & 2,31 & 2,31 & \\
5 & 13,42 & 13,80 & 9,66 & 2,31 \\
10 & 18,99 & 14,47 & 11,47 & 5,40 \\
20 & 22,64 & 11,16 & 9,83 & 4,45 \\
35 & 16,11 & 12,13 & 9,93 & 5,77 \\
45 & 13,03 & 6,72 & 6,83 & 4,90 \\
\hline
\end{tabular}

c.v. $=11,22$

Tabela A8: Efeito de diferentes fontes de carbono na concentração de proteína ( $\mu \mathrm{g}$ proteína/mg peso seco) de células em suspensão de Curcuma zedoaria Roscoe.

\begin{tabular}{cllll}
\hline \multicolumn{5}{c}{ Fontes de carbono } \\
\hline $\begin{array}{r}\text { Tempo de } \\
\text { crescimento } \\
\text { (dias) }\end{array}$ & Sacarose & Sorbitol & Galactose & Glicerol \\
\hline 0 & 8,23 & 8,23 & 8,23 & \\
5 & 16,53 & 14,34 & 10,76 & 8,23 \\
10 & 8,45 & 4,82 & 7,08 & 2,69 \\
20 & 12,86 & 7,52 & 7,04 & 1,93 \\
35 & 8,99 & 4,82 & 5,66 & 1,05 \\
45 & 7,07 & 2,26 & 3,24 & 1,84 \\
\hline
\end{tabular}

$$
\text { c.v. }=19,15
$$


Tabela A9: Efeito de diferentes fontes de carbono na concentração de proteína ( $\mu \mathrm{g}$ proteína/mg peso seco) de células em suspensão de Phaseolus vulgaris.

\begin{tabular}{lllll}
\hline \multicolumn{5}{c}{ Fontes de carbono } \\
\hline $\begin{array}{r}\text { Tempo de } \\
\text { crescimento } \\
\text { (dias) }\end{array}$ & Sacarose & Sorbitol & Galactose & Glicerol \\
\hline 0 & 4,83 & 4,83 & 4,83 & \\
5 & 10,76 & 5,11 & 7,45 & 4,83 \\
10 & 8,36 & 6,32 & 5,49 & 4,21 \\
20 & 7,68 & 8,47 & 3,56 & 3,61 \\
35 & 11,65 & 4,35 & 4,89 & 3,10 \\
45 & 14,78 & 4,33 & 3,56 & 3,08 \\
\hline
\end{tabular}

$$
\text { c.v. }=13,34
$$

Tabela A10: Análise da variância para a variável massa fresca de Bauhinia forficata Link.

\begin{tabular}{lll}
\hline FATORES & G.L. & Q.M. \\
\hline fonte & 3 & $3.06^{* *}$ \\
tempo & 9 & $0.27^{*}$ \\
fonteXtempo & 27 & 0.17 \\
blocos & 3 & $1.13^{* *}$ \\
\hline
\end{tabular}


Tabela A11: Análise da variância da regressão polinomial para a variável massa fresca de Bauhinia forficata Link.

\begin{tabular}{lll}
\hline CONTRASTES & G.L. & Q.M. \\
\hline tempo dentro de galactose & 9 & 0.03 \\
RL & 1 & 0.03 \\
RQ & 1 & 0.05 \\
RC & 1 & 0.00 \\
tempo dentro de glicerol & 9 & 0.06 \\
RL & 1 & 0.04 \\
RQ & 1 & 0.11 \\
RC & 1 & 0.05 \\
tempo dentro de sacarose & 9 & $0.60^{* *}$ \\
RL & 1 & $4.25^{* *}$ \\
RQ & 1 & 0.13 \\
RC & 1 & 0.02 \\
tempo dentro de sorbitol & 9 & 0.12 \\
RL & 1 & 0.06 \\
RQ & 1 & 0.24 \\
RC & 1 & 0.05 \\
\hline
\end{tabular}

Tabela A12: Análise da variância para a variável massa seca de Bauhinia forficata Link.

\begin{tabular}{lll}
\hline FATORES & G.L. & Q.M. \\
\hline fonte & 3 & $1.22^{* *}$ \\
tempo & 9 & $0.39^{* *}$ \\
fonteXtempo & 27 & 0.16 \\
blocos & 3 & $1.46^{* *}$ \\
\hline
\end{tabular}


Tabela A13: Análise da variância da regressão polinomial para a variável massa seca de Bauhinia forficata Link.

\begin{tabular}{lll}
\hline CONTRASTES & G.L. & Q.M. \\
\hline tempo dentro de galactose & 9 & 0.05 \\
RL & 1 & 0.09 \\
RQ & 1 & 0.20 \\
RC & 1 & 0.00 \\
tempo dentro de glicerol & 9 & 0.11 \\
RL & 1 & 0.20 \\
RQ & 1 & 0.00 \\
RC & 1 & 0.30 \\
tempo dentro de sacarose & 9 & $0.56^{* *}$ \\
RL & 1 & $3.82^{* *}$ \\
RQ & 1 & 0.15 \\
RC & 1 & 0.00 \\
tempo dentro de sorbitol & 9 & 0.15 \\
RL & 1 & 0.11 \\
RQ & 1 & 0.21 \\
RC & 1 & 0.06 \\
\hline
\end{tabular}

Tabela A14: Análise da variância para a variável proteína de Bauhinia forficata Link.

\begin{tabular}{lll}
\hline FATORES & G.L. & Q.M. \\
\hline fonte & 3 & $0.35^{* *}$ \\
tempo & 5 & $0.39^{* *}$ \\
fonteXtempo & 15 & 0.02 \\
blocos & 3 & 0.06 \\
\hline
\end{tabular}


Tabela A15: Análise da variância da regressão polinomial para a variável proteina de Bauhinia forficata Link.

\begin{tabular}{lll}
\hline CONTRASTES & G.L. & Q.M. \\
\hline tempo dentro de galactose & 5 & $0.10^{* *}$ \\
RL & 1 & $0.12^{*}$ \\
RQ & 1 & $0.34^{* *}$ \\
RC & 1 & 0.02 \\
tempo dentro de glicerol & 5 & 0.02 \\
RL & 1 & 0.05 \\
RQ & 1 & 0.03 \\
RC & 1 & 0.00 \\
tempo dentro de sacarose & 5 & $0.21^{* *}$ \\
RL & 1 & $0.44^{* *}$ \\
RQ & 1 & $0.59^{* *}$ \\
RC & 1 & 0.03 \\
tempo dentro de sorbitol & 5 & $0.14^{*}$ \\
RL & 1 & 0.05 \\
RQ & 1 & $0.49^{*}$ \\
RC & 1 & 0.08 \\
\hline
\end{tabular}

Tabela A16: Análise da variância para a variável massa fresca de Curcuma zedoaria Roscoe.

\begin{tabular}{lll}
\hline FATORES & G.L. & Q.M. \\
\hline fonte & 3 & $13.02^{* *}$ \\
tempo & 9 & $0.63^{*}$ \\
fonteXtempo & 27 & $0.84^{* *}$ \\
blocos & 3 & $1.93^{* *}$ \\
\hline
\end{tabular}


Tabela A17: Análise da variância da regressão polinomial para a variável massa fresca de Curcuma zedoaria Roscoe.

\begin{tabular}{lll}
\hline CONTRASTES & G.L. & Q.M. \\
\hline tempo dentro de galactose & 9 & 0.10 \\
RL & 1 & 0.56 \\
RQ & 1 & 0.19 \\
RC & 1 & 0.00 \\
tempo dentro de glicerol & 9 & 0.08 \\
RL & 1 & 0.45 \\
RQ & 1 & 0.06 \\
RC & 1 & 0.00 \\
tempo dentro de sacarose & 9 & $2.95^{* *}$ \\
RL & 1 & $18.92^{* *}$ \\
RQ & 1 & $1.74^{*}$ \\
RC & 1 & $4.95^{* *}$ \\
tempo dentro de sorbitol & 9 & 0.03 \\
RL & 1 & 0.07 \\
RQ & 1 & 0.00 \\
RC & 1 & 0.01 \\
\hline
\end{tabular}

Tabela A18: Análise da variância para a variável massa seca de Curcuma zedoaria Roscoe.

\begin{tabular}{lll}
\hline FATORES & G.L. & Q.M. \\
\hline fonte & 3 & $3.24^{* *}$ \\
tempo & 9 & $1.09^{* *}$ \\
fontextempo & 27 & $0.54^{* *}$ \\
blocos & 3 & $2.69^{* *}$ \\
\hline
\end{tabular}


Tabela A19: Análise da variância da regressão polinomial para a variável massa seca de Curcuma zedoaria Roscoe.

\begin{tabular}{lll}
\hline CONTRASTES & G.L. & Q.M. \\
\hline tempo dentro de galactose & 9 & 0.22 \\
RL & 1 & $1.60^{* *}$ \\
RQ & 1 & 0.12 \\
RC & 1 & 0.15 \\
tempo dentro de glicerol & 9 & 0.19 \\
RL & 1 & 0.05 \\
RQ & 1 & $1.03^{*}$ \\
RC & 1 & 0.34 \\
tempo dentro de sacarose & 9 & $2.14^{* *}$ \\
RL & 1 & $11.08^{* *}$ \\
RQ & 1 & $4.57^{* *}$ \\
RC & 1 & $2.91^{* *}$ \\
tempo dentro de sorbitol & 9 & 1.49 \\
RL & 1 & 0.01 \\
RQ & 1 & 0.62 \\
RC & 1 & 0.55 \\
\hline
\end{tabular}

Tabela A20: Análise da variância para a variável proteína de Curcuma zedoaria Roscoe.

\begin{tabular}{lll}
\hline FATORES & G.L. & Q.M. \\
\hline fonte & 3 & $0.52^{* *}$ \\
tempo & 5 & $0.23^{* *}$ \\
fonteXtempo & 15 & 0.05 \\
blocos & 3 & $0.23^{*}$ \\
\hline
\end{tabular}


Tabela A21: Análise da variância da regressão polinomial para a variável proteína de Curcuma zedoaria Roscoe.

\begin{tabular}{lll}
\hline CONTRASTES & G.L. & Q.M. \\
\hline tempo dentro de galactose & 5 & 0.03 \\
RL & 1 & 0.11 \\
RQ & 1 & 0.01 \\
RC & 1 & 0.00 \\
tempo dentro de glicerol & 5 & $0.18^{*}$ \\
RL & 1 & $0.71^{* *}$ \\
RQ & 1 & 0.10 \\
RC & 1 & 0.00 \\
tempo dentro de sacarose & 5 & 0.03 \\
RL & 1 & 0.04 \\
RQ & 1 & 0.04 \\
RC & 1 & 0.03 \\
tempo dentro de sorbitol & 5 & 0.15 \\
RL & 1 & $0.54^{* *}$ \\
RQ & 1 & 0.14 \\
RC & 1 & 0.01 \\
\hline
\end{tabular}

Tabela A22: Análise da variância para a variável massa fresca de Phaseolus vulgaris.

\begin{tabular}{lll}
\hline FATORES & G.L. & Q.M. \\
\hline fonte & 3 & $26.67^{* *}$ \\
tempo & 9 & 0.52 \\
fonteXtempo & 27 & $1.83^{* *}$ \\
blocos & 3 & $8.53^{* *}$ \\
\hline
\end{tabular}


Tabela A23: Análise da variância da regressão polinomial para a variável massa fresca de Phaseolus vulgaris.

\begin{tabular}{lll}
\hline CONTRASTES & G.L. & Q.M. \\
\hline tempo dentro de galactose & 9 & 0.31 \\
RL & 1 & $1.53^{*}$ \\
RQ & 1 & 0.31 \\
RC & 1 & 0.17 \\
tempo dentro de glicerol & 9 & 0.33 \\
RL & 1 & $2.23^{* *}$ \\
RQ & 1 & 0.20 \\
RC & 1 & 0.13 \\
tempo dentro de sacarose & 9 & $5.24^{* *}$ \\
RL & 1 & $42.13^{* *}$ \\
RQ & 1 & 0.20 \\
RC & 1 & 0.80 \\
tempo dentro de sorbitol & 9 & 0.12 \\
RL & 1 & 0.87 \\
RQ & 1 & 0.00 \\
RC & 1 & 0.00 \\
\hline
\end{tabular}

Tabela A24: Análise da variância para a variável massa seca de Phaseolus vulgaris.

\begin{tabular}{lll}
\hline FATORES & G.L. & Q.M. \\
\hline fonte & 3 & $15.99^{* *}$ \\
tempo & 9 & 0.78 \\
fontextempo & 27 & $1.45^{* *}$ \\
blocos & 3 & $9.73^{* *}$ \\
\hline
\end{tabular}


Tabela A25: Análise da variância da regressão polinomial para a variável massa seca de Phaseolus vulgaris.

\begin{tabular}{lll}
\hline CONTRASTES & G.L. & Q.M. \\
\hline tempo dentro de galactose & 9 & 0.15 \\
RL & 1 & 0.60 \\
RQ & 1 & 0.02 \\
RC & 1 & 0.21 \\
tempo dentro de glicerol & 9 & 0.26 \\
RL & 1 & 0.91 \\
RQ & 1 & 0.00 \\
RC & 1 & 0.44 \\
tempo dentro de sacarose & 9 & $4.66^{* *}$ \\
RL & 1 & $36.32^{* *}$ \\
RQ & 1 & 0.00 \\
RC & 1 & $1.15^{*}$ \\
tempo dentro de sorbitol & 9 & 0.06 \\
RL & 1 & 0.12 \\
RQ & 1 & 0.10 \\
RC & 1 & 0.05 \\
\hline
\end{tabular}

Tabela A26: Análise da variância para a variável proteína de Phaseolus vulgaris.

\begin{tabular}{lll}
\hline FATORES & G.L. & Q.M. \\
\hline fonte & 3 & $0.20^{*}$ \\
tempo & 5 & 0.02 \\
fontextempo & 15 & 0.04 \\
blocos & 3 & $0.16^{*}$ \\
\hline
\end{tabular}


Tabela A27: Análise da variância da regressão polinomial para a variável proteína de Phaseolus vulgaris.

\begin{tabular}{lll}
\hline CONTRASTES & G.L. & Q.M. \\
\hline tempo dentro de galactose & 5 & 0.19 \\
RL & 1 & 0.04 \\
RQ & 1 & 0.00 \\
RC & 1 & 0.01 \\
tempo dentro de glicerol & 5 & 0.02 \\
RL & 1 & 0.03 \\
RQ & 1 & 0.03 \\
RC & 1 & 0.01 \\
tempo dentro de sacarose & 5 & $0.08^{*}$ \\
RL & 1 & $0.25^{* *}$ \\
RQ & 1 & 0.06 \\
RC & 1 & 0.00 \\
tempo dentro de sorbitol & 5 & 0.03 \\
RL & 1 & 0.00 \\
RQ & 1 & 0.01 \\
RC & 1 & 0.02 \\
\hline
\end{tabular}

